
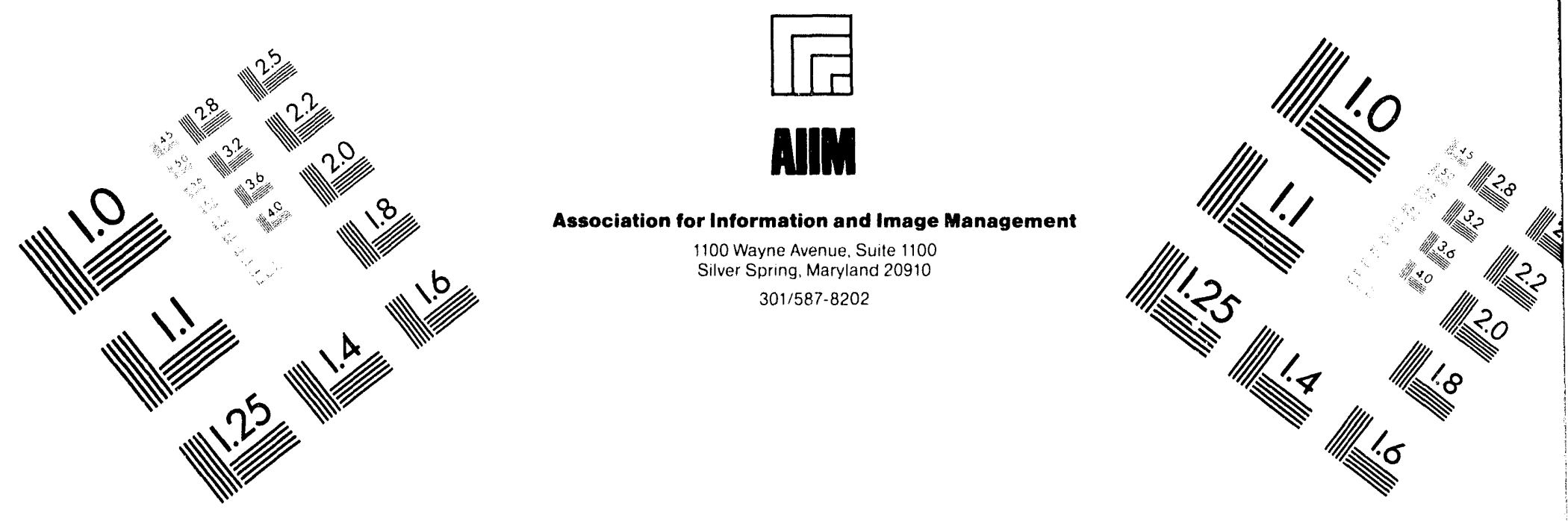

\title{
Centimeter
}

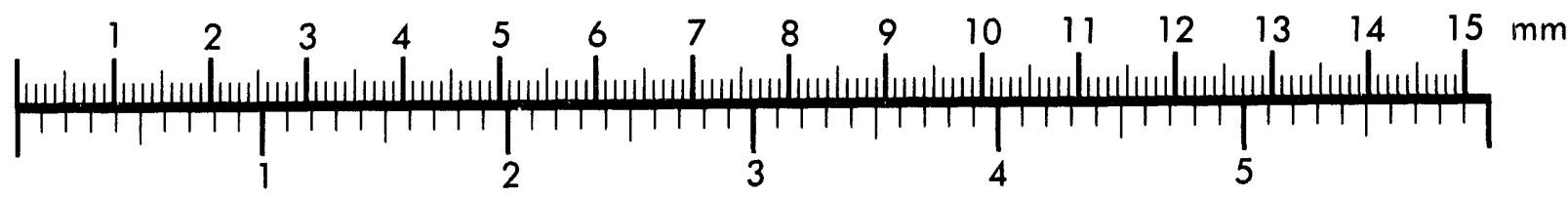
Inches
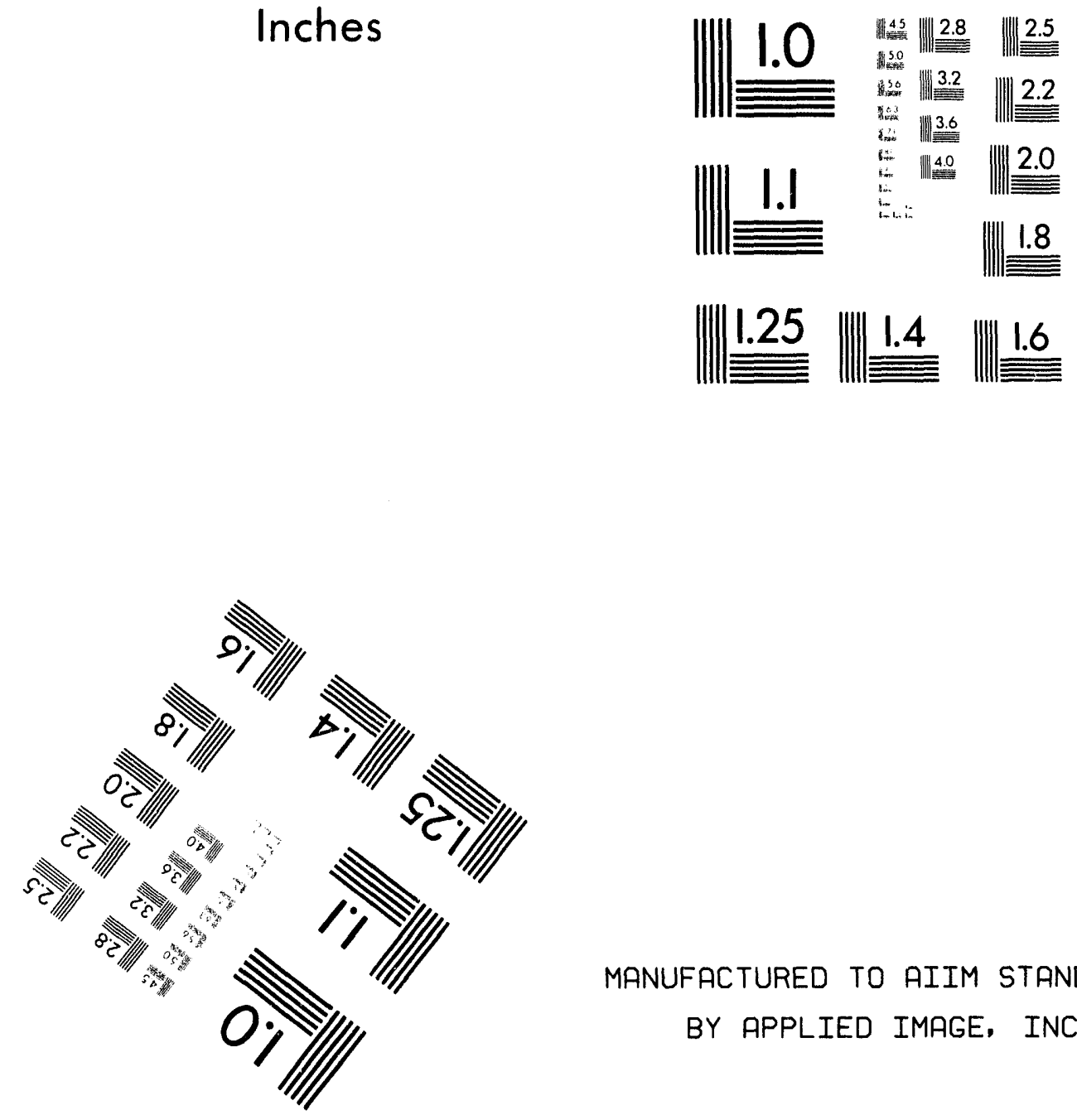

MANUFACTURED TO AIIM STANDARDS

BY APPLIED IMAGE, INC.

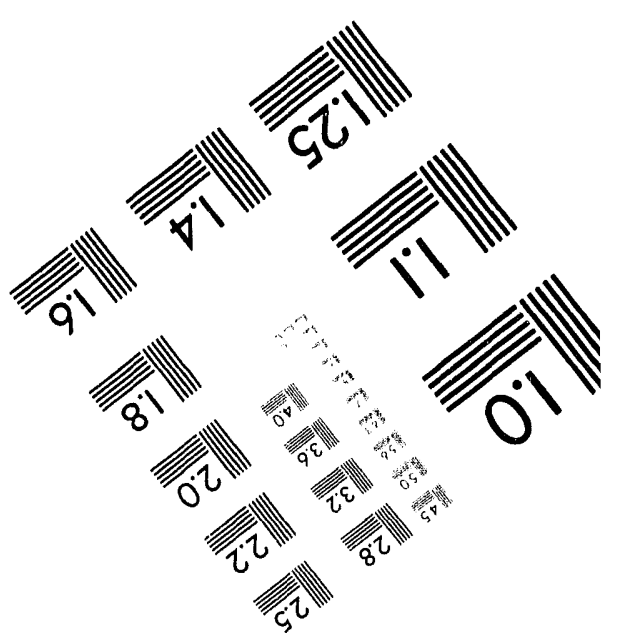



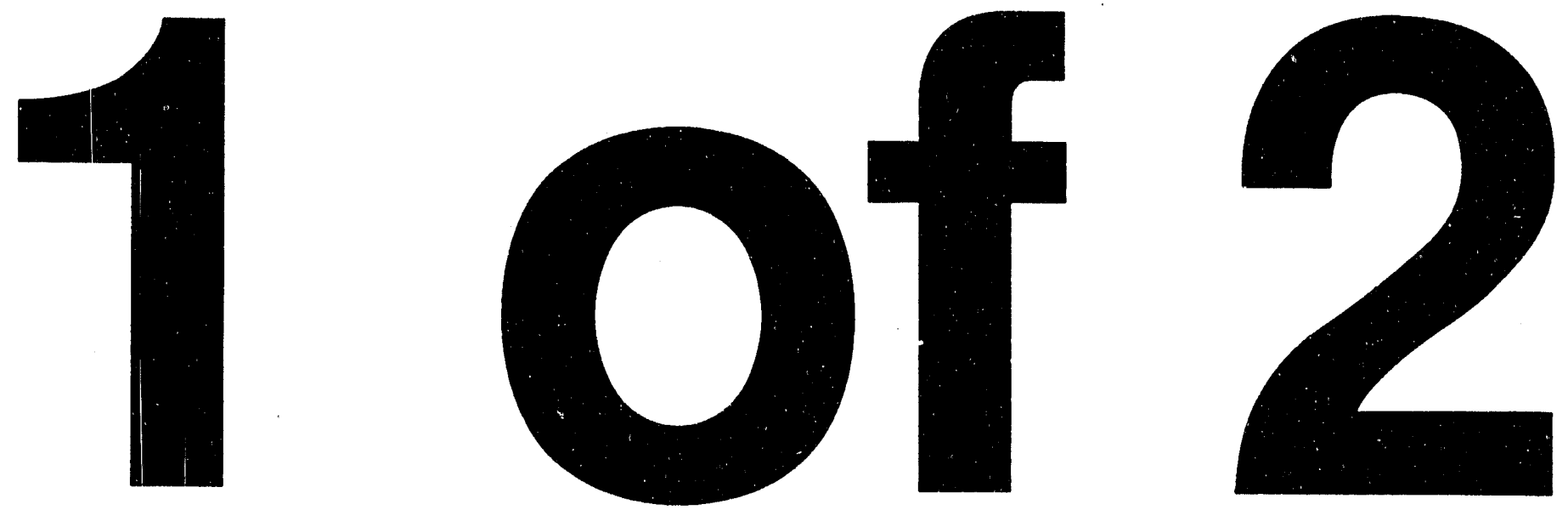


\section{Instructions for the Preparation of Resource Allocation Support System (RASS) Data Forms}

by T.E. Baldwin, W.A. Buehring, M.J. Jusko, J.M. Keisler, R.G. Whitfield, and T.D. Wolsko

Decision and Information Sciences Division,

Argonne National Laboratory, 9700 South Cass Avenue, Argonne, Illinois 60439

March 1994

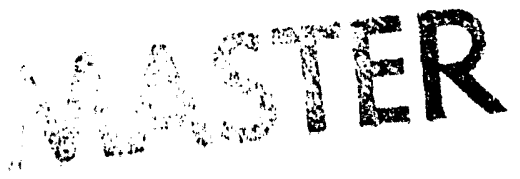

Work sponsored by United States Department of Energy,

Office of Environmental Restoration and Waste Management

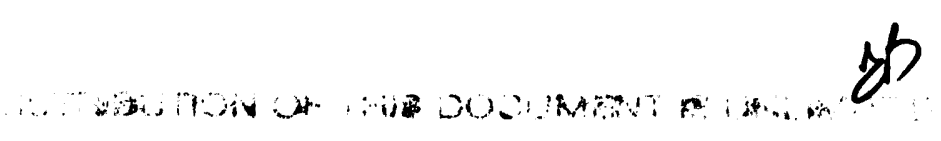




\section{CONTENTS}

ACKNOWLEDGMENTS $\ldots \ldots \ldots \ldots \ldots \ldots \ldots \ldots \ldots \ldots \ldots \ldots \ldots \ldots \ldots$ vi

NOTATION $\ldots \ldots \ldots \ldots \ldots \ldots \ldots \ldots \ldots \ldots \ldots \ldots \ldots \ldots \ldots \ldots$ vii

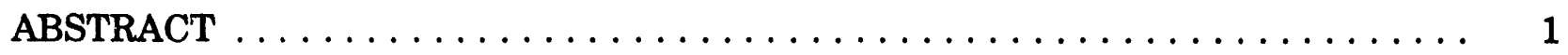

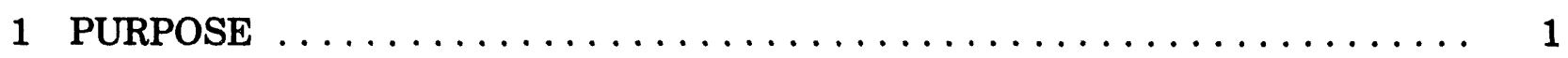

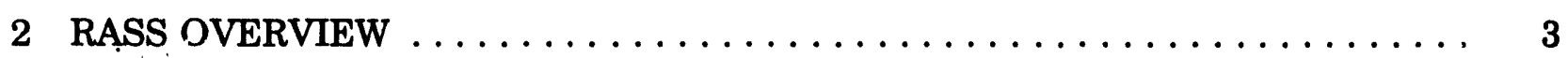

2.1 WM Objectives and Subobjectives Used by RASS $\ldots \ldots \ldots \ldots \ldots \ldots$

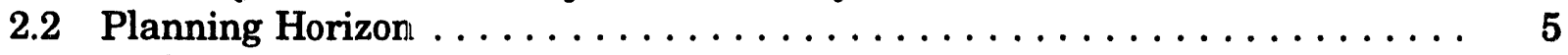

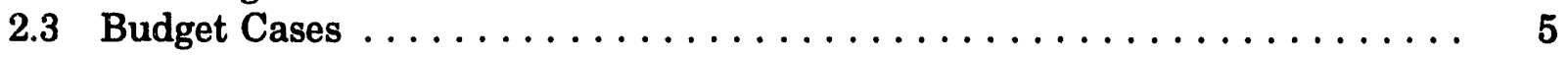

3 INSTRUCTIONS FOR COMPLETING THE RASS FORMS $\ldots \ldots \ldots \ldots \ldots .8$

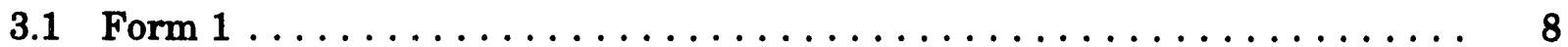

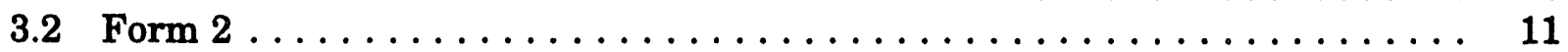

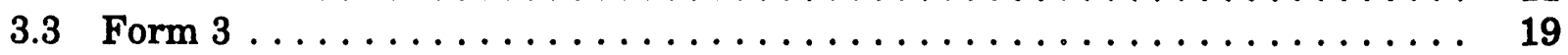

APPENDIX A: Proposed Data Entry Forms and Worksheets ........... 25

APPENDIX B: Constructed Scales for Use in the Resource Allocation

Support System .................... 35

APPENDIX C: Examples of Completed Resource Allocation Support System

Data Forms and Worksheets $\ldots \ldots \ldots \ldots \ldots \ldots \ldots \ldots$

APPENDIX D: Resource Allocation Support System Data Forms 2 and 3:

Background Information $\ldots \ldots \ldots \ldots \ldots \ldots \ldots \ldots \ldots \ldots$

APPENDIX E: $\quad$ Glossary $\ldots \ldots \ldots \ldots \ldots \ldots \ldots \ldots \ldots \ldots \ldots \ldots \ldots \ldots \ldots \ldots$

\section{FIGURES}

1 Objectives and Subobjectives Used in RASS $\ldots \ldots \ldots \ldots \ldots \ldots \ldots \ldots$

2 Relationships between Objectives, Subobjectives, and

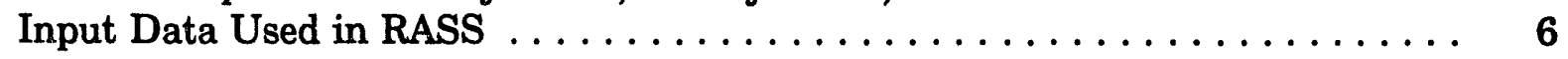

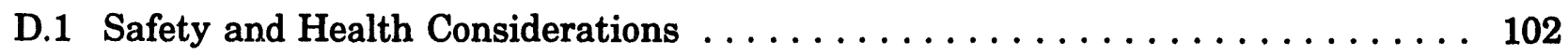

D.2 Three Categories of Waste Managed Activities $\ldots \ldots \ldots \ldots \ldots \ldots \ldots$ 
$1 \quad$ Data Required for RASS Form 1 , Lines $1-14 \ldots \ldots \ldots \ldots \ldots \ldots$

2 Yearly Data Required for RASS Form 2, Lines 15-36 . . . . . . . . . . 12

$3 \quad$ Data Required for RASS Form 3 , Lines $37-41 \ldots \ldots \ldots \ldots \ldots \ldots$

B.1 Constructed Scale for Compliance $\ldots \ldots \ldots \ldots \ldots \ldots \ldots \ldots \ldots \ldots \ldots$

B.2 Air and Water Morbidity Code: Constructed Scale for Public

Safety and Health Morbidity Effects Due to Air and Water

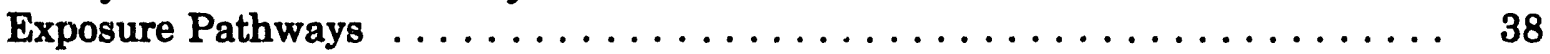

B.3 Air and Water Mortality Code: Constructed Scale for Public Safety and Health Mortality Effects Due to Air and Water

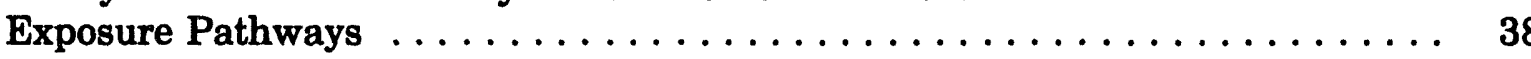

B.4 Risk to Future Generations: Type of Waste Left On-site . . . . . . . . 39

B.5 Risk to Future Generations: Potential for Releases to the Accessible Environment over 10,000 Years . . . . . . . . . . . . . .

B.6 New Capacity Status: Constructed Scale for Estimating Schedule Delays in Providing New Treatment, Storage, or Disposal Capacity ........................... 40

B.7 Constructed Scale for Public Concern $\ldots \ldots \ldots \ldots \ldots \ldots \ldots \ldots \ldots \ldots \ldots, 40$

B.8 Cultural Impacts: Significance of the Site under Consideration

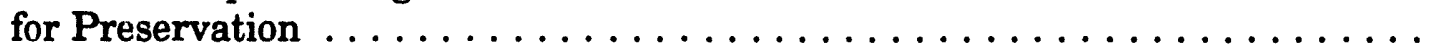

B.9 Cultural Impacts: Damage to the Site or Interference

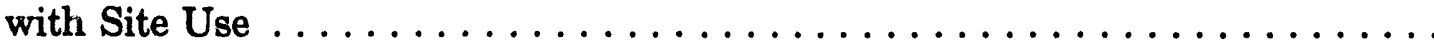

B.10 Short-Term Land Use: Quality of and Demand for Land

B.11 Long-Term Land Use: Characteristics of the Waste Permanently Disposed of On-site

B.12 Biotic Impacts: Sensitivity of Biota $\ldots \ldots \ldots \ldots \ldots \ldots \ldots \ldots \ldots \ldots \ldots, 43$

B.13 Biotic Impacts: Damage to Biota $\ldots \ldots \ldots \ldots \ldots \ldots \ldots \ldots \ldots \ldots \ldots$

B.14 Natural Resource Impacts: Sensitivity of Natural Resource . . . . . . . . . . 44

B.15 Natural Resource Impacts: Damage to Natural Resource $\ldots . \ldots \ldots \ldots \ldots 44$ 


\section{TABLES (Cont.)}

C.1 Description of Funding Unit for Hanford Waste Processing

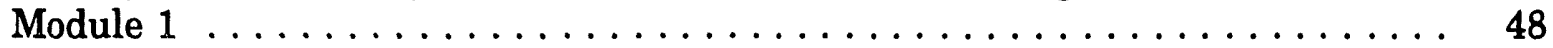

C.2 Explanation of Attachments for an Example Funding Unit $\ldots \ldots \ldots \ldots \ldots$

D.1 Constructed Scale for Compliance $\ldots \ldots \ldots \ldots \ldots \ldots \ldots \ldots \ldots \ldots$

D.2 Air and Water Morbidity Code: Constructed Scale for Public

Safety and Health Morbidity Effects Due to Air and Water

Exposure Pathways . . . . . . . . . . . . . . . . . . . . 103

D.3 Air and Water Mortality Code: Constructed Scale for Public

Safety and Health Mortality Effects Due to Air and Water

Exposure Pathways ............................ 104

D.4 Risk to Future Generations: Type of Waste Left On-site . . . . . . . . . . . . 104

D.5 Risk to Future Generations: Potential for Releases to the

Accessible Environment over 10,000 Years . . . . . . . . . . . . . . 105

D.6 New Capacity Status: Constructed Scale for Estimating Schedule

Delays in Providing New Treatment, Storage,

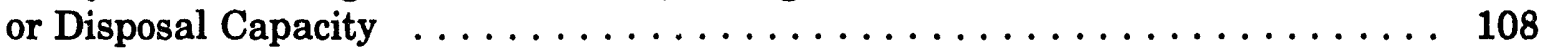

D.7 Constructed Scale for Public Concern $\ldots \ldots \ldots \ldots \ldots \ldots \ldots \ldots \ldots \ldots \ldots$

D.8 Cultural Impacts: Significance of the Site under Consideration

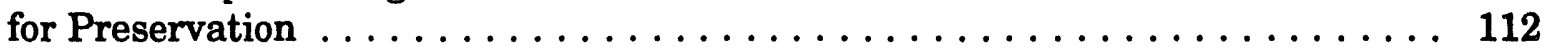

D.9 Cultural Impacts: Damage to the Site or Interference

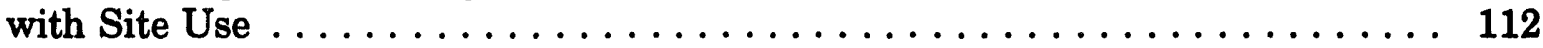

D.10 Shcrt-Term Land Use: Quality of and Demand for Land ............ 113

D.11 Long-Term Land Use: Characteristics of Waste Permanently Disposed On-site ........................... 113

D.12 Biotic Impacts: Sensitivity of Biota $\ldots \ldots \ldots \ldots \ldots \ldots \ldots \ldots \ldots \ldots \ldots$

D.13 Biotic Impacts: Damage to Biota . . . . . . . . . . . . . . . . . . 115

D.14 Natural Resource Impacts: Sensitivity of Natural Resource . . . . . . . . . 116

D.15 Natural Resource Impacts: Damage to Natural Resource $\ldots \ldots \ldots \ldots \ldots \ldots$ 


\section{ACKNOWLEDGMENTS}

The authors wish to thank several individuals for their contributions to this document. James Turi and Kevin Donovan of the U.S. Department of Energy provided guidance and encouragement throughout the preparation of this document. Detlof von Winterfeldt of the University of Southern California developed materials for new objectives and measurement scales that were added after completion of the 1992 Resource Allocation Support System pilot study. Ralph Keeney of the University of Southern California and John Shideler of J.K. Research Associates reviewed a draft of this document and provided many helpful comments. Argonne National Laboratory's Information and Publishing Division provided publishing support; Margaret Clemmons did the technical editing and Linda Haley and Mary Jo Koelbl prepared the graphics. Finally, many members of the public generously gave their time to discuss early development plans for the system. The authors have implemented a number of their suggestions and have attempted to address as many of their concerns as possible. However, these acknowledgments do not imply endorsement of this report. The content and opinions expressed herein are the sole responsibility of the authors. 


\title{
NOTATION
}

\author{
ADS activity data sheet \\ CFR Code of Federal Regulations \\ DOE U.S. Department of Energy \\ EM Office of Environmental Restoration and Waste Management (DOE) \\ ES\&H environmental safety and health \\ FY fiscal year \\ ID identification (number) \\ NA not applicable \\ NRC U.S. Nuclear Regulatory Commission \\ RASS Resource Allocation Support System \\ S\&H safety and health \\ TDD task description document \\ TSD treatment, storage, and disposal (of waste) \\ WM Office of Waste Management (DOE)
}




\title{
INSTRUCTIONS FOR THE PREPARATION OF RESOURCE ALLOCATION SUPPORT SYSTEM (RASS) DATA FORMS
}

\author{
by \\ T.E. Baldwin, W.A. Buehring, M.J. Jusko, J.M. Keisler, \\ R.G. Whitfield, and T.D. Wolsko
}

\begin{abstract}
The Resource Allocation Support System (RASS) is a decision-aiding system being developed to assist the U.S. Department of Energy's Office of Waste Management in program and budget decision making. Information about proposed work, developed by DOE program managers and contractors, comprises what is called the RASS database. A set of data forms and worksheets (paper copies) are provided to record information that will be entered into the RASS database. This report contains instructions for preparing the data forms and worksheets.
\end{abstract}

\section{PURPOSE}

Each year, the U.S. Department of Energy's (DOE's) Office of Environmental Restoration and Waste Management (EM) prepares a document describing work planned for a five- year pexiod. Additional quantitative information is needed to support the necessity for and value of planned work. In response to this need, EM's Office of Waste Management (WM) has funded the development of the Resource Allocation Support System (RASS) - a decision-aiding system to assist its program and budget decision-making process.

If and when RASS is integrated into the annual planning and decision-making process, project managers will need to provide data for determining the degree to which proposed work supports WM's programmatic objectives. These data will be input to RASS. Data forms and associated worksheets have been developed to help project managers provide the necessary data.

This report introduces the basic concepts required to understand what data are needed for RASS and provides a step-by-step guide to aid project managers in filling out the data entry forms and supporting worksheets. Appendixes A through E respectively include proposed data entry forms and worksheets, constructed scales, examples of completed RASS data forms and worksheets, more detailed information about the scales that project managers will use in estimating the effectiveness of WM projects, and a glossary. 
After reading Section 2 (RASS Overview), you should have a completed sample form from Appendix $\mathrm{C}$ on hand as an example of how each line of the data forms might be filled out. After studying the instructions and the completed example, you will be ready to complete blank forms and worksheets (Appendix A) for a proposed activity. The forms are completed in a manner similar to the way in which individual Internal Revenue Service tax returns are completed. Copies of the blank forms, line-by-line instructions, and planning documents necessary to complete the forms should all be readily accessible. 


\section{RASS OVERVIEW}

The RASS process promotes the systematic analysis of alternative sets of proposed WM activities to determine their effectiveness in satisfying WM program objectives. To understand this process, it is necessary to define three related terms specific to RASS: activity, funding unit, and funding unit alternative.

An activity is a specific proposal for work, such as new construction; an upgrade to an existing facility; routine maintenance; treating, storing, or disposing of waste; and monitoring the environment.

A funding unit - the decision unit in RASS - is a logical grouping of related activities consistent with WM program planning (e.g., work breakdown structure). Examples of funding units are an installation (e.g., Ames Laboratory or Kinsas City Plant) a facility (e.g., Toxic Substances Control Act Incinerator), or a major activity (e.g., environmental monitoring at a large installation). Installations that have large WM budgets (e.g., Oak Ridge, Richland, and Savannah River) may have many funding units, and installations that have small WM kudgets (e.g., Ames Laboratory) may have only one funding unit.

A funding unit alternative is a specific set of proposed activities for a particular funding unit. Each funding unit has a number of funding unit alternatives that correspond to different assumptions regarding budget, schedule, and so on, for a particular year. Given a total WM budget (either hypothetical or actual) for a particular year and "scores" (i.e., ratings) for each funding unit alternative, RASS identifies the combination of funding unit alternatives that best satisfies the WM objectives used by RASS.

A critical step in the RASS process is for project managers to score proposed alternative activities. The following sections provide basic information that project managers will need to understand the process used for scoring proposed alternative activities. In this process, measurement scales for the seven WM objectives used by RASS are used to gauge the effectiveness of work proposed at WM sites.

\subsection{WM OBJECTIVES AND SUBOBJECTIVES USED BY RASS}

Figure 1 provides an overview of the WM objectives and subobjectives used by RASS. Subobjectives, when present, are more specific than their associated objectives (e.g., safety and health [S\&H] issues include risks to the public and to workers). The subobjectives are comprehensive, independent dimensions used to evaluate proposed WM activities. Scores (usually numeric data for subobjectives) developed by DOE program managers reflect the degree to which related WM objectives are met. More than one subobjective is used for most objectives. 
Objectives
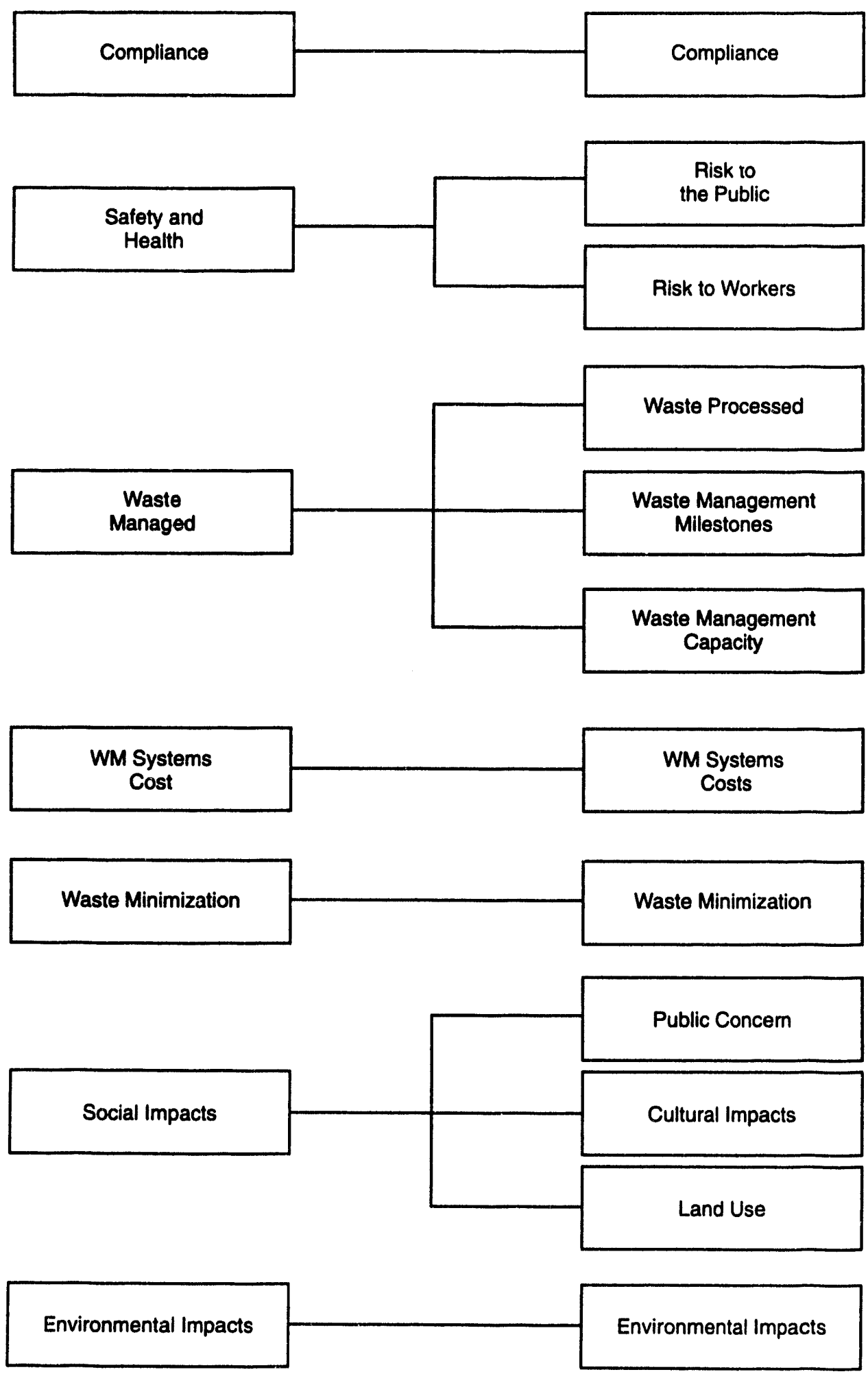

FIGURE 1 Objectives and Subobjectives Used in RASS 
The scores for the objectives, developed by DOE and contractor program managers, form the basis for an overall "figure of merit" for each funding unit alternative. This figure of merit represents the degree to which each of the many objectives is met. Figure 2 shows the relationships among WM objectives, subobjectives, and the input data used in RASS. The numbers given with each type of input data in Figure 2 correspond to the respective line numbers used in RASS forms 2 and 3 (Appendix A), which are filled out by the project managers.

\subsection{PLANNING HORIZON}

The planning horizon for waste management activities is generally five years (beginning with the first year of the five-year planning period under consideration). For RASS evaluation, the planning horizon (time interval for planning) can vary from 1 to more than 20 years. Long-term activities could be scored for the complete life cycle of the project. However, to ensure thiat the effort required to score such projects is kept to a reasonable amount, RASS input data only need to be furnished for the budget year, out-years 1-4, and a typical "far-out-year" (i.e., a representative year beyond out-year 4).

\subsection{BUDGET CASES}

The following budget cases have been established to help define funding unit alternatives that will be used in the RASS analysis:

- The standby alternative includes funding to maintain equipment or a facility in a ready-to-operate (standby) mode, but operating funds are not provided. Activities are addressed only in the standby mode and usually would meet all compliance requirements for this level of operation.

- The intermediate alternative represents a funding option between the standby and operations alternatives.

- The operations alternative includes operating, maintenance, and capital expenses needed to conduct scheduled WM activities in a safe, efficient manner that ensures compliance with all applicable laws, treaties, regulations, agreements, and DOE orders. This alternative usually corresponds to the "target" funding request prepared for the fiscal year (FY) 1994-1998 Five-Year Plan.

- The long-range alternative includes new facility upgrades or construction as well as facilities that offer long-range benefits to the waste management system. This alternative might correspond to the "planning" funding request prepared for the FY 1994-1998 Five-Year Plan. 
Objectives

Subobjectives
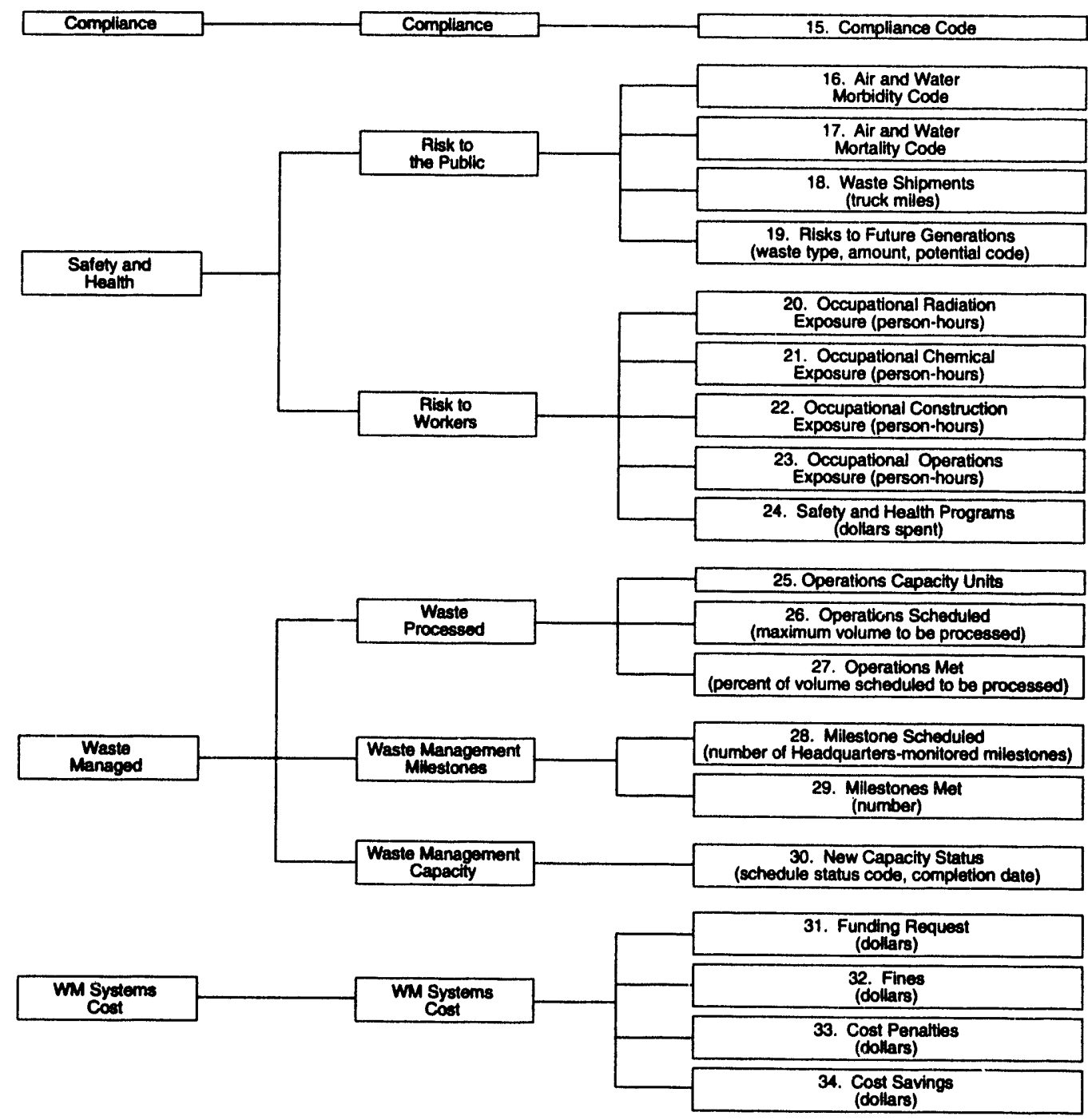

\begin{tabular}{|c|c|c|}
\hline $\begin{array}{c}\text { Waste } \\
\text { Minimization }\end{array}$ \\
\hline $\begin{array}{c}\text { Social } \\
\text { Impacts }\end{array}$
\end{tabular}

\begin{tabular}{|c|}
$\begin{array}{c}\text { 40. Blotic Impacts } \\
\text { (sensiltity and damage codes) }\end{array}$ \\
\hline $\begin{array}{c}\text { 41. Natural Resource Impacts } \\
\text { (sensitivity and damage codes) }\end{array}$ \\
\hline
\end{tabular}

The number indlcates the line number in RASS activities forms 2 and 3.

FIGURE 2 Relationships between Objectives, Subobjectives, and Input Data Used in RASS 
It is expected that four funding unit alternatives will be prepared for each funding unit; however, it may be appropriate to have more or less than four alternatives. It is also expected that future documentation of RASS alternatives will be coordinated with planning activities so that budget cases can be used to prepare alternatives for RASS activities. Nevertheless, additional effort beyond the normal budget preparation will be needed to characterize funding unit alternatives for RASS. 


\section{INSTRUCTIONS FOR COMPLETING THE RASS FORMS}

This section provides basic instructions for completing the three forms used to record data to be input to RASS. Specific entries are designated by lines 1 through 14 (form 1), 15 through 36 (form 2), and 37 through 41 (form 3). Appendix D contains detailed information that describes how to determine scores for lines 15 through 41 in forms 2 and 3.

You must complete one set of forms for each activity in a funding unit alternative. In addition, some data entries (for forms 2 and 3 ) require "side calculations" that should be recorded on separate worksheets.

To complete a form for a proposed activity, first study the completed example shown in Appendix C, pages 60-94, and then photocopy the blank forms in Appendix A. Next, complete each form, one line at a time, and enter the corresponding information on the worksheets and notes sections before progressing to the next line of the main form.

\subsection{FORM 1}

RASS form 1 requires identification information about the preparer (name, date, and telephone number) and the funding unit alternative (names of installation, funding unit, activity, and alternative; waste and activity type; and facility status). Project managers need to record the data listed in Table 1. A brief description of the information required for each line is given below.

\section{Line 1. Record ID}

Record a unique ID number that will be used to identify this funding unit, activity, and alternative. It is suggested that the format $X . Y Z$ be used, where $X$ denotes the funding unit number, $Y$ the activity number, and $Z$ the alternative number. For example, 1.11 would denote funding unit 1 , activity 1 , and alternative 1 . If more than nine activities make up a funding unit, it may be desirable to use letter codes to denote activities. Be consistent in assigning alternative numbers (e.g., let 1 denote standby; 2 , intermediate; 3 , operations; and 4, long range).

\section{Line 2. ADS/TDD}

Record the ADS or TDD number(s) that apply to this record.

\section{Line 3. Date}

Enter the date on which the form was prepared or modified. 
TABLE 1 Data Required for RASS Form 1, Jines 1-14

\begin{tabular}{cl}
$\begin{array}{c}\text { Line } \\
\text { No. }\end{array}$ & \multicolumn{1}{c}{ Data Required } \\
\hline 1 & Record identification (ID) number \\
2 & $\begin{array}{l}\text { Activity Data Sheet (ADS)/Task Description } \\
\text { Document (TDD) ID number }\end{array}$ \\
3 & Date \\
4 & Preparer \\
5 & Phone \\
6 & Field office \\
7 & Installation name \\
8 & Funding unit name \\
9 & Activity name \\
10 & Alternative name \\
11 & Waste type \\
12 & Activity type \\
13 & Facility status \\
\hline 14 & Notes \\
\hline
\end{tabular}

\section{Line 4. Preparer}

Enter the name of the person who prepared the form. This person should be the point of contact for clarification of information contained in the form.

\section{Line 5. Phone}

Enter the telephone number (with area code) of the preparer named on line 4 .

\section{Line 6. Field Office}

Check the name of the DOE field office that is responsible for the activity. 


\section{Line 7. Installation Name}

Enter the name of the installation (e.g., Argonne National Laboratory-East) or facility that will carry out the activity.

\section{Line 8. Funding Unit Name}

Enter the name of the funding unit (e.g., environmental monitoring) in which this activity occurs. All activities within a funding unit should use the same funding unit name.

\section{Line 9. Activity Name}

Enter the name of the activity (e.g., PCB [polychlorinated biphenyls] Contaminated Sludge Remediation). A funding unit can be composed of several activities. If a funding unit consists of more than one activity, each activity must be identified by the same field office, installation, and funding unit names.

\section{Line 10. Alternative Name}

Enter the name of the funding unit alternative (e.g., standby, intermediate, operations, or long range) or provide another descriptive name, if appropriate.

\section{Line 11. Waste Type}

Enter the type of waste managed by the activity by checking the appropriate box on the form. If "Other" is selected, describe the nature of the activity on the blank line; enter additional information either in the "notes" space (line 14) or in a separate attachment. If the activity involves multiple waste types, complete a form for each type of waste because RASS processes each type of waste separately.

\section{Line 12. Activity Type}

Enter the type of waste management activity (e.g., treatment, storage, disposal, transportation) by checking the appropriate box on the form. If the waste type is Other, enter the activity type on the blank line.

\section{Line 13. Facility Status}

Enter the status of the facility by checking the appropriate box on the form. Check "proposed" if the facility is not yet in operation. Check "existing" if the facility is in operation. Leave line 13 blank if the waste type is Other. 


\section{Line 14. Notes}

State assumptions, information sources, and other clarifying data about lines 1-13 in the notes space. If you require additional space, include notes in a separate attachment.

\subsection{FORM 2}

Form 2 (shown on page 29) requires mostly numeric data and letter codes, for a series of years, about the funding unit alternative. Lines 15 through 36 require yearly data for areas listed in Table 2.

The information required for each line in form 2 is briefly described below. The discussion concerns entries for one year but can apply to any year, including the "typical farout-year." The typical far-out-year is representative of one or more years (the number of years must also be specified) after the year 2000 .

You need to be careful to enter the record ID number in the upper right corner. This number identifies the field office, installation, funding unit, activity, and alternative to which the worksheet applies. It should be the same ID number used on the associated form 1 .

\section{Line 15. Compliance Code}

Enter the letter (A-H) that corresponds to the "state" of compliance that may result at the funding level specified for a particular year:
$\mathrm{A}=$ Full compliance;
B = Nonconformity with a DOE reference standard or good practice guidance;
$\mathrm{C}=$ Delay in meeting a Tiger Team milestone;
$\mathrm{D}$ = Violation of a mandatory standard;
$\mathrm{E}=$ Accommodation request that leads tó a negotiated compliance schedule;
F = Dispute in a Tri-Party Agreement that leads to work stoppage;
G = Dispute in a Tri-Party Agreement or Native American treaty that leads to litigation; or
$\mathrm{H}=$ Accommodation request (refused) that leads to a shutdown of certain operations.


TABLE 2 Yearly Data Required for RASS Form 2, Lines 15-36

Line

No. Data Required

15 Compliance code

16 Air and water morbidity code

17 Air and water mortality code

18 Waste shipments

19 Risk to future generations

20 Radiation exposure (occupational)

21 Chemical exposure (occupational)

22 Construction (occupational)

23 Operations (occupational)

24 S\&H programs

25 Operations capacity units

26 Operations scheduled

27 Operations met

28 Milestones scheduled

29 Milestones met

30 New capacity status

$31 \quad$ Funding request

$32 \quad$ Fines

33 Cost penalties

34 Cost savings

35 Waste minimization

36 Public concern code 
If you enter a letter other than A (which designates full compliance), go to line 15 of worksheet 2 (found in Appendixes $A$ and $C$ ) and record notes on the relevant law, regulation, order, agreement, and so on, in the area provided for describing the compliance issue. If the compliance code is uncertain, use line 15 of worksheet 2 to indicate plausible outcomes.

Entries in the worksheet are probabilities that indicate the relative likelihoods of outcomes. For example, a 0.75 probability (or 3/4) for level A and a 0.25 probability (or $1 / 4$ ) for level $\mathrm{E}$ means that level $\mathrm{A}$ is three times as likely to occur as level $\mathrm{E}$, and no other outcome is possible. The probability for any letter is always between 0 and 1 . The sum of all probabilities in a specific year must equal 1.

If several potential compliance nonconformities or violations are possible, use a separate worksheet for each nonconformity or violation. For each worksheet, the sum of the probabilities in a specific year must equal 1.

\section{Line 16. Air and Water Morbidity Code}

Enter the letter (A-E) that indicates the plausible extent of morbidity impacts on the public from air or water exposure pathways:
$A=$ No cases of sickness or fatalities;
$B=U p$ to 1 case of sickness;
$C=U p$ to 10 cases of sickness;
$D=U p$ to 100 cases of sickness; or
$E=$ More than 100 cases of sickness.

If the outcome is uncertain, record the probabilities on worksheet 2, line 16 . Refer to the discussion about entering the record identification number and probabilities (line 15) for more details. If the entry is anything other than $A$, include notes that give details, especially if the entry is $E$ (which represents an interval with no upper limit).

\section{Line 17. Air and Water Mortality Code}

Enter the letter (A-E) that indicates the plausible extent of mortality impacts on the public from air or water exposure pathways:
$A=$ No fatalities;
$B=U p$ to 1 fatality;
$C=$ Up to 10 fatalities; 


$$
\begin{aligned}
& D=U p \text { to } 100 \text { fatalities; or } \\
& E=\text { More than } 100 \text { fatalities. }
\end{aligned}
$$

If the outcome is uncertain, record the probabilities on worksheet 2, line 17 . Refer to the discussion about entering the record identification number and probabilities (line 15) for more details. If the entry is anything other than $A$, include notes that give details, especially if the entry is $E$ (which represents an interval with no upper limit).

\section{Line 18. Waste Shipments}

Enter the number of truck-miles associated with the transport of waste in this activity, if applicable.

\section{Line 19. Risk to Future Generations}

\section{Line 19a. Waste Type Code}

Enter the letter (A-E) that corresponds to the type of waste generated in this activity that will affect future generations:
$A=$ Wastes that are neither hazardous nor radioactive;
B = Hazardous metals;
C = Low-level radioactive wastes;
D = Mixed wastes; or
$E$ = High-level or transuranic wastes.

\section{Line 19b. Amount of Waste and Unit of Measure}

Enter the amount of waste and unit of measure noted on line 19a that is generated or remains after this activity is completed.

\section{Line 19c. Potential for Release Code}

Enter the letter (A-D) that corresponds to the potential for release of the waste noted on line 19a. If the potential is uncertain, record the probabilities for the following levels on line $19 \mathrm{c}$ of worksheet 2 : 

$A=$ No potential for releases;
$B=$ Very low potential for releases (comparable to repository storage with favorable environmental conditions);
$\mathrm{C}=$ Low potential for releases (comparable to monitored retrieval storage with favorable environmental conditions); or
D = Some potential for releases (comparable to underground vault storage with unfavorable environmental conditions).

For more details about entering probabilities and the record identification number, refer to the discussion for line 15 .

\section{Line 20. Radiation Exposure}

Enter the number of person-hours of radiation exposure for workers. Include radiation exposures during construction (both new construction and upgrades) and routine operations. Do not include support or administrative persornel.

\section{Line 21. Chemical Exposure}

Enter the number of person-hours of chemical exposure for workers. Include chemical exposures during construction (both new construction and upgrades) and routine operations. Do not include support or administrative personnel.

\section{Line 22. Construction}

Enter the number of person-hours to be expended on construction projects. Do not include support or administrative personnel.

\section{Line 23. Operations}

Enter the number of person-hours required for operating waste management facilities. Do not include administrative and support personnel.

\section{Line 24. S\&H Programs}

Enter the dollar amount (in thousands of current-year dollars) to be used for programs (e.g., training or protective equipment) intended to reduce S\&H risks. 


\section{Line 25. Operating Capacity Units (units for line 26)}

Indicate the unit of measure of capacity/throughput for the waste involved in the activity by checking the appropriate box. If this activity does not directly involve the treatment, storage, or disposal of waste, leave the line blank. If the appropriate units are not listed, check Other and explain (e.g., collect and analyze groundwater samples).

\section{Line 26. Operations Scheduled}

Enter the reference capacity or reference throughput (i.e., the largest amount of waste managed among the funding unit alternatives) for each year. In most cases, this level will correspond to the amount for the long-range funding unit alternative. If no capacity or throughput is planned for a particular year, enter zero.

\section{Line 27. Operations Met}

Enter the percentage of the capacity or throughput (of that noted on line 26), that can be met at the requested level of funding. If the entry on line 26 is "NA" (not applicable) or 0 , enter $0 \%$.

\section{Line 28. Milestones Scheduled}

Enter the reference number of Headquarters-tracked Five-Year Plan milestones scheduled for each year. In most cases, the reference number will correspond to the long-range alternative.

\section{Line 29. Milestones Met}

Enter the number of Headquarters-tracked milestones (of those noted on line 28, Milestones Scheduled) that can be met at the requested funding level for each year.

\section{Line 30. New Capacity Status}

\section{Line 30a. Schedule Status Code}

Enter the letter (A-J) that best describes the schedule status for construction activities:

$A$ = No delay;

$B=A$ delay that lasts 1 to 6 months, with completion scheduled after out-year 1; 
$\mathrm{C}=\mathrm{A}$ delay that lasts 1 to 6 months, with completion scheduled for out-year 1;

$\mathrm{D}=\mathrm{A}$ delay that lasts 1 to 6 months, with completion scheduled for the budget year;

$\mathrm{E}=\mathrm{A}$ delay that lasts 7 to 12 months, with completion scheduled after out-year 1;

$F=A$ delay that lasts 7 to 12 months, with completion scheduled for out-year 1;

$\mathrm{G}=\mathrm{A}$ delay that lasts 7 to 12 months, with completion scheduled for the budget year;

$\mathrm{H}=\mathrm{A}$ delay that lasts more than 12 months, with completion scheduled after out-year 1 ;

$\mathrm{I}=\mathrm{A}$ delay that lasts more than 12 months, with completion scheduled for out-year 1 ; or

$J=A$ delay that lasts more than 12 months, with completion scheduled for the budget year.

It is anticipated that level A (no delay) will be appropriate in most situations. Entries of level H, I, or $J$ (which represent delays with no upper limit) are not expected and will require further explanation, which should be provided in the notes area at the end of worksheet 2 . If no construction activity is scheduled, enter NA (not applicable). If the status is uncertain, use line 30a of worksheet 2 to record the probabilities. For more details about entering probabilities and the record identification number, refer to the discussion for line 15 . If the delay depends on a combination of activities included in the funding unit alternative, specify the delay only once (in the first of the activities involved) for the entire alternative.

\section{Line 30b. Completion Date}

Enter the "reference" completion date for new capacity/throughput. This reference date is the earliest completion date possible among the proposed funding unit alternatives. If no construction activity is scheduled, enter NA.

\section{Line 31. Funding Request}

Enter the amount of funding requested (in millions of current-year dollars) in the budget year and anticipated in each of the out-years, as appropriate. Use escalation rates provided in DOE Headquarters' guidance for out-year calculations. If funding is needed 
beyond out-year 4, either enter a "typical" cost estimate (e.g., the average cost) in the next-to-last column and the number of years for which this cost estimate applies or provide cost estimates for each year in a separate attachment.

Typical year costs should be expressed in current-year dollars for out-year 4. For example, if the budget year were 1996, out-year 4 would be 2000 , and costs should be expressed in 1996 dollars; in contrast, funding requests for the years 2001-2020 should be given in terms of year $\mathbf{2 0 0 0}$ dollars.

If the activity is to be funded for only one budget year, entries for the out-years are not needed. If the entries for the operations funding unit alternative are nearly the same as those for the other funding unit alternatives, it is easier to photocopy the form for a completed alternative and then note the changes between alternatives.

\section{Line 32. Fines}

If fines from regulatory agencies are likely for this activity, enter the total (in millions of current-year dollars). In an attachment, itemize the fines, identify the levying agencies, and describe the nature of the fines for each year. If space is available, use the notes area on worksheet 2.

\section{Line 33. Cost Penalties}

If this activity increases costs for other funding units, enter the total increases (in millions of current-year dollars) for the years in which that happens. In an attachment, name the affected funding units. If space is available, use the notes area on worksheet 2.

\section{Line 34. Cost Savings}

If this activity reduces costs for other funding units, "claim" those cost savings (in millions of current-year dollars) for the years in which that happens. In an attachment, name the affected funding units. If space is available, use the notes area on worksheet 2.

\section{Line 35. Waste Minimization}

Enter the amount of funding (in millions of current-year dollars) to be used for programs intended to reduce the amount of waste produced. Such activities include recycling, engineering, and training. 


\section{Line 36. Public Concern Code}

Enter the letter (A-E) that corresponds to the situation that is most comparable to the level of public concern that results from this activity. The public concern letter codes and their meanings are as follows:

$A=$ No public concern (e.g., no local residents express fear or mistrust about this activity; regional activist groups do not oppose this activity; and no national political or media attention results from this activity);

$B=$ Minor public concern (e.g., a few residents express fear or mistrust about this activity; one regional activist group opposes this activity);

$\mathrm{C}=$ Moderate public concern (e.g., $10 \%$ of residents express fear or mistrust about this activity; several regional activist groups oppose this activity; minor national media coverage and some national political interest result from this activity);

$\mathrm{D}=$ High public concern (e.g., $50 \%$ of residents express fear or mistrust about this activity; most regional waste management activist groups oppose this activity; substantial national media coverage and possible congressional action result from this activity); or

$\mathbf{E}=$ Very high public concern (e.g., 75\% of residents express fear or mistrust about this activity; all regional waste management groups, activist groups, and others oppose this activity; frequent national media coverage and congressional investigations result from this activity).

If the level of concern is uncertain, record the probabilities on line 36 of worksheet 2. For more details about entering the record identification number and probabilities, refer to the discussion for line 15 .

\subsection{FORM 3}

Form 3 requires data that pertain to cultural and environmental issues. Lines 37 through 41 of form 3 address the areas listed in Table 3. You need to be careful to enter the record ID number at the upper right corner. This number identifies the field office, installation, funding unit, activity, and alternative to which the worksheet applies. It should be the same ID number used on the associated form 1 and form 2 . 


\begin{tabular}{cc} 
TABLE 3 & Data Required for \\
RASS Form 3, Lines 37-41 \\
\hline $\begin{array}{cc}\text { Line } \\
\text { No. }\end{array}$ & Data Required \\
\hline 37 & Cultural impacts \\
38 & Short-term land use \\
39 & Long-term land use \\
40 & Biotic impacts \\
41 & Natural resource impacts \\
\hline
\end{tabular}

\section{Line 37. Cultural Impacts}

\section{Line 37a. Significance Code}

Enter the letter (A-D) that corresponds to the historical, archaeological, or religious significance of sites affected by this activity:
$A=$ No significance;
B = Local significance;
$\mathrm{C}=$ Regional significance; or
D = National significance.

If the level of significance is uncertain, record the probabilities on line 37a of worksheet 3 . For more details about entering the record identification number and probabilities, refer to the discussion for line 15.

\section{Line 37b. Damage Code}

Enter the letter (A-D) that corresponds to the level of damage from this activity to sites of historical, archaeological, or religious significance:

$A=$ No damage to the site or interference with its use;

$B=$ Site access is restricted for 25 years, but no damage occurs; 
$\mathrm{C}=50 \%$ of site is damaged; or

D = Site is destroyed completely or can never be reused.

If the level of damage is uncertain, record the probabilities on line $37 \mathrm{~b}$ of worksheet 3. For more details about entering the record identification number and probabilities, refer to the discussion for line 15.

\section{Line 38. Short-Term Land Use}

\section{Line 38a. Quality and Demand Code}

Enter the letter (A-E) that corresponds to the description that most closely applies to land whose use will be restricted by this activity:

$A=$ No use of or demand for the land;

B = Low-quality land with low demand (generally undeveloped);

$\mathrm{C}$ = Moderate-quality land with moderate demand (agricultural);

D = High-quality land with moderate demand (proposed homes); or

$E$ = High-quality land with high demand (homes, tribal claims).

If the quality and demand are uncertain, record the probabilities on line 38a of worksheet 3. For more details about entering the record identification number and probabilities, refer to the discussion for line 15.

\section{Line 38b. Time of Restriction}

Enter the number of years that land use will be restricted by this activity.

\section{Line 38c. Amount of Land} activity.

Enter the number of acres of land whose use will be restricted by this 


\section{Line 39. Long-Term Land Use}

\section{Line 39a. Characteristics Code}

Enter the letter (A-F) that indicates the type of waste permanently disposed of on-site by this activity:
$A$ = No harmful wastes;
$B=$ Hazardous organic wastes;
$\mathrm{C}=$ Hazardous metals;
D = Mixed hazardous metals and low-level radioactive wastes;
$\mathrm{E}=$ Mixed hazardous wastes with some high-level components; or
$F=$ Transuranic or high-level wastes.

If the characteristics of the waste are uncertain, record the probabilities on line 39a of worksheet 3. For more details about entering the record identification number and probabilities, refer to the discussion for line 15.

\section{Line 396. Amount of Land}

Enter the amount of land (in acres) that is permanently restricted from access as a result of waste disposal activities on this site.

\section{Line 40. Biotic Impacts}

\section{Line 40a. Sensitivity Code}

Enter the letter (A-D) that corresponds to the level of sensitivity of species (in terms of survival) affected by this activity:
$A=$ Species are not sensitive, unique, or threatened/endangered;
$B$ = Species are sensitive, but not unique to area or threatened/ endangered;
C = Species are sensitive and unique to area, but not threatened/ endangered; or
D = Species are threatened/endangered. 
If the sensitivity of the species involved is uncertain, record the probabilities on line 40a of worksheet 3. For more details about entering the record identification number and probabilities, refer to the discussion for line 15 .

\section{Line 40b. Damage Code}

Enter the letter (A-F) that corresponds to the level of damage caused to species or their habitats by this activity:
$A=$ No damage;
B = Minor behavior changes of some species, no reduction of species;
$\mathrm{C}=$ Minor (5\%) reduction of species;
$\mathrm{D}=$ Significant $(25 \%)$ reduction of species;
$\mathrm{E}=$ Major (50\%) reduction of species; or
$F=$ Elimination of species or their habitat.

If the level of damage to biota is uncertain, record the probabilities on line $40 \mathrm{~b}$ of worksheet 3 . For more details about entering the record identification number and probabilities, refer to the discussion for line 15.

\section{Line 41. Natural Resource Impacts}

\section{Line 41a. Sensitivity Code}

Enter the letter (A-E) that indicates the level of sensitivity of natural resources affected by this activity:
$A=$ Not environmentally sensitive;
$\mathrm{B}=$ State-designated natural area or scenic/wild river;
$\mathrm{C}=$ Partially developed coastal barrier or federally designated scenic/wild river;
D = Natural preserve, national or state wildlife refuge, undeveloped coastal barrier, or federal land designated for protection of natural ecosystems; or



$\mathbf{E}=$ Marine sanctuary, national park, designated federal wilderness area, national monument, or national seashore or lakeshore recreational area.

If the sensitivity of natural resources is uncertain, record the probabilities on line 41a of worksheet 3. For more details about entering the record identification number and probabilities, refer to the discussion for line 15.

\section{Line 41b. Damage Code}

Enter the letter (A-F) that corresponds to the level of damage caused to natural resources by this activity:
$A=$ No degradation of use or damage;
$B=$ Aesthetic degradation of use only;
$\mathrm{C}=$ Degradation of use through noise, vibration, and aesthetic impacts;
D = Minor (5\%) loss of natural resource;
$E=$ Significant (25\%) loss of natural resource; or
$F=$ Major (50\%) loss of natural resource.

If the level of damage to natural resources is uncertain, record the probabilities on line $41 \mathrm{~b}$ of worksheet 3 . For more details about entering probabilities, refer to the discussion for line 15. 
APPENDIX A:

PROPOSED DATA ENTRY FORMS AND WORKSHEETS 


\section{APPENDIX A:}

\section{PROPOSED DATA ENTRY FORMS AND WORKSHEETS}

This appendix contains worksheets and data entry forms to be used to input data into the Resource Allocation Support System (RASS). Three forms are included, along with two worksheets that supplement the forms. Worksheet 2 is associated with form 2 and worksheet 3 with form 3 . These worksheets are mainly used when probability distributions must be specified for one of the constructed scales. They can also be used to record additional textual material. Samples of completed forms and worksheets are presented in Appendix C. 


\section{RASS Activities: Form 1}

Record ID:

ADS/TDD:

Date:

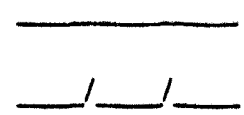

Preparer:

Phone:

Field ofice: (check one)
$\square \mathrm{AL}$ Albuquerque
$\square \mathrm{CH}$ Chicago
$\square$ ID Idaho
$\square$ NV Nevada
RL Richland
$\square$ FS Fernald
$\square$ OR Oak Ridge
$\square \mathrm{HQ}$ Headquarters
$\square$ RF Rocky Flats
$\square$ SF San Francisco
$\square$ SR Savannah River

7 Installation name:

8 Funding unit name:

9 Activity name:

10 Alternative name:

11

Waste type: (check one)

$\square$ TRU

$\square$ HLW

$\square$ LLW

$\square$ Hazardous

12

13

14 $\square$ Treatment
$\square$ Disposal

(check one)

Facility status: $\square$ Proposed

(check one) $\square$ Existing
Notes: $\square$ Mixed

$\square$ Sanitary

$\square$ Industrial waste water

$\square$ Other: $\square$ Storage

$\square$ Transportation

$\square$ Other: 
RASS Activities: Form 2

\begin{tabular}{|c|c|c|c|c|c|c|c|}
\hline \multirow[b]{2}{*}{ Input Data } & \multirow{2}{*}{$\begin{array}{c}\text { Budget } \\
\text { Year } \\
1996\end{array}$} & \multicolumn{4}{|c|}{ Out-Years } & \multirow{2}{*}{$\begin{array}{l}\text { Typical } \\
\text { Year } \\
>2000\end{array}$} & \multirow{2}{*}{$\begin{array}{l}\text { \# of } \\
\text { Typica } \\
\text { Years }\end{array}$} \\
\hline & & 1997 & 1998 & 1999 & 2000 & & \\
\hline $\begin{array}{l}\text { Compliance code: } \\
\text { (enter A-H. or use worksheet } D \text { ) }\end{array}$ & & & & & & & \\
\hline $\begin{array}{r}\text { 16Air \& water morbidity code: } \\
\text { (enter A-E,or enter use worksheet } \square \text { ) }\end{array}$ & & & & & & & \\
\hline $\begin{array}{r}17 \text { Air \& water mortality code: } \\
\text { (enser A-E. or use worksheet } \square)\end{array}$ & & & & & & & \\
\hline $\begin{array}{r}\text { Waste shipments: } \\
\text { (truck-miles) }\end{array}$ & & & & & & & \\
\hline
\end{tabular}

19 Risk to future generations:

a.

b.

c.
Waste type code:

Amount of land:

Potential code:
(A-E)

(acres)

(enter A-D, or use worksheet $\square$ )

\begin{tabular}{|lr|}
\hline 20 & Radiation exposure (per-h): \\
\hline 21 & Chemical exposure $($ per-h): \\
\hline 22 & Construction $($ per-h): \\
\hline 23 & Operations $($ per-h): \\
\hline 24 & S\&H programs $(\$):$ \\
\hline
\end{tabular}

Units for line 26: $\square \mathrm{m}^{3}$ (check one) $\square$ gallons $\square \mathrm{ft}^{3}$ $\square$ lbs.

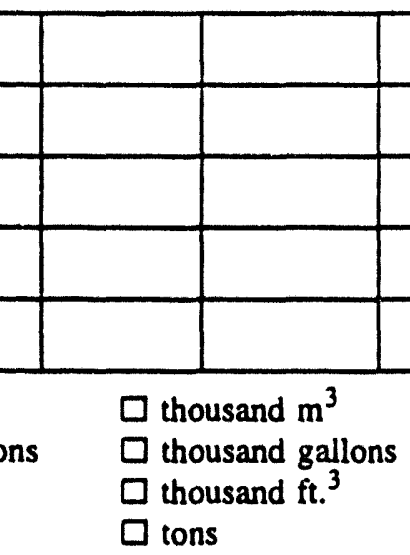

\begin{tabular}{|l|l|l|l|}
\hline & & & \\
\hline & & & \\
\hline & & & \\
\hline & & & \\
\hline & & & \\
\hline
\end{tabular}

25
$\square$ million $\mathrm{m}^{3}$
$\square$ barrels
$\square$ million $\mathrm{ft}^{3}$

$\square$ other

\begin{tabular}{|r|l|l|l|l|l|l|l|}
\hline $26 r$ Operations scheduled: & & & & & & & \\
\hline 27 Operations met (percent): & & & & & & & \\
\hline $28 \quad$ Milestones scheduled: & & & & & & & \\
\hline $29 \quad$ Milestones met: & & & & & &
\end{tabular}

30 New capacity status: a. Schedule status code:

b. Completion date:

(enter A.J, or use worksheet $\square$ )

\begin{tabular}{|r|r|r|l|l|l|l|l|}
\hline $31 \quad$ Funding request (SiM): & & & & & & & \\
\hline $32 \quad$ Fines (SM): & & & & & & & \\
\hline $33 \quad$ Cost penalties (SM): & & & & & & & \\
\hline $34 \quad$ Cost savings (SiM): & & & & & & & \\
\hline $35 \quad$ Waste minimization (SiM): & & & & & & & \\
\hline $36 \quad \begin{array}{r}\text { Public concern code: } \\
\text { (enter A-E. or use worksheet } \square)\end{array}$ & & & & & & & \\
\hline
\end{tabular}


RASS Activities: Form 3

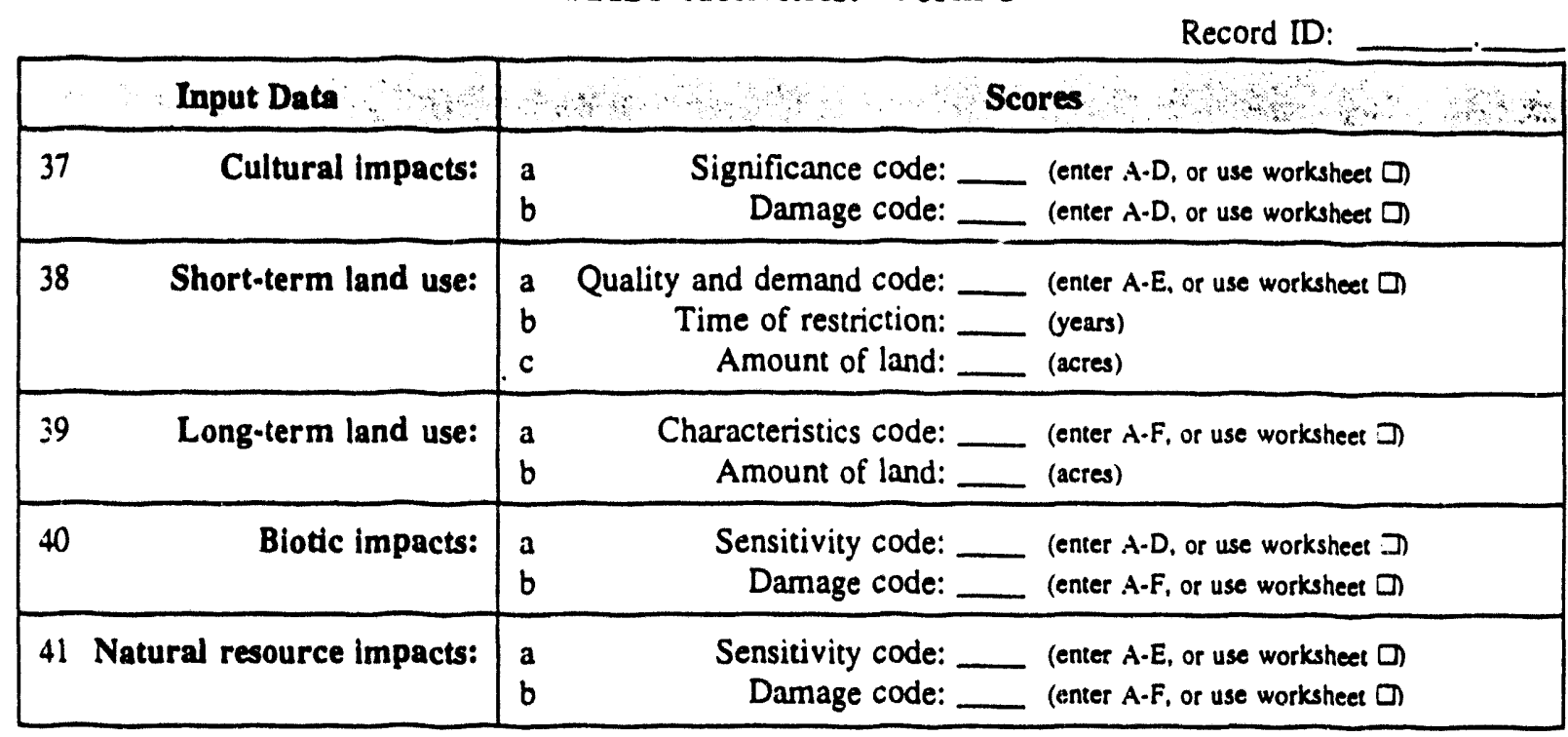

Notes: 
RASS Activities: Worksheet 2

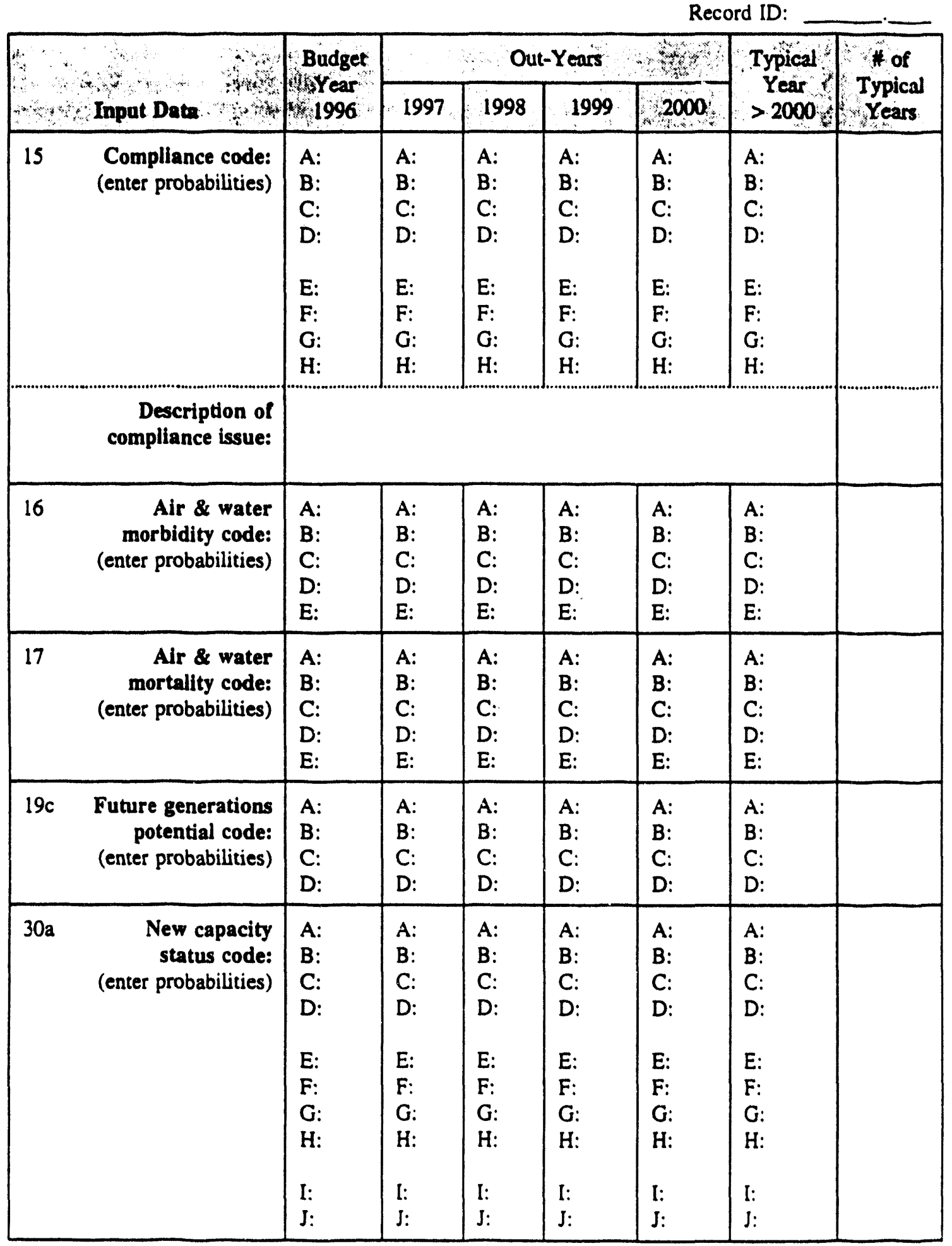


RASS Activities: Worksheet 2 (cont'd)

\begin{tabular}{|c|c|c|c|c|c|c|c|}
\hline \multirow{3}{*}{ Input Data } & \multirow{3}{*}{$\begin{array}{l}\text { Budget } \\
\text { Year } \\
\text { 1996 }\end{array}$} & & & & \multicolumn{3}{|c|}{ Record ID: } \\
\hline & & \multicolumn{3}{|c|}{ Out-Years } & 2 & \multirow{2}{*}{$\begin{array}{l}\text { Typical } \\
\text { Year } \\
>2000\end{array}$} & \multirow{2}{*}{$\begin{array}{l}\text { \# of } \\
\text { Typical } \\
\text { XY ears }\end{array}$} \\
\hline & & 1997 & 1998 & 1999 & 2000 & & \\
\hline $\begin{array}{r}\text { Public concern code: } \\
\text { (enter probabilities) }\end{array}$ & $\begin{array}{l}\text { A: } \\
\text { B: } \\
\text { C: } \\
\text { D: } \\
\text { E: }\end{array}$ & $\begin{array}{l}\text { A: } \\
\text { B: } \\
\text { C: } \\
\text { D: } \\
\text { E: }\end{array}$ & $\begin{array}{l}\text { A: } \\
\text { B: } \\
\text { C: } \\
\text { D: } \\
\text { E: }\end{array}$ & $\begin{array}{l}\text { A: } \\
\text { B: } \\
\text { C: } \\
\text { D: } \\
\text { E: }\end{array}$ & $\begin{array}{l}\text { A: } \\
\text { B: } \\
\text { C: } \\
\text { D: } \\
\text { E: }\end{array}$ & $\begin{array}{l}\text { A: } \\
\text { B: } \\
\text { C: } \\
\text { D: } \\
\text { E: }\end{array}$ & \\
\hline
\end{tabular}

Notes: 
RASS Activities: Worksheet 3

\begin{tabular}{|c|c|c|}
\hline \multicolumn{2}{|c|}{ Record ID: } & \\
\hline ry & 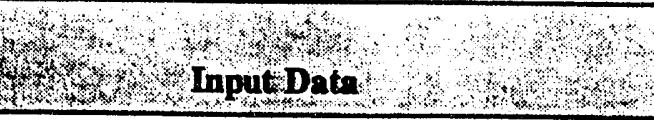 & Probabilities \\
\hline $37 a$ & Cuitural impacts significance: & $\begin{array}{l}\text { A: } \\
\text { B: } \\
\text { C: } \\
\text { D: }\end{array}$ \\
\hline $37 b$ & Cultural impacts damage: & $\begin{array}{l}\text { A: } \\
\text { B: } \\
\text { C: } \\
\text { D: }\end{array}$ \\
\hline & Short-term land use quality and demand: & $\begin{array}{l}\text { A: } \\
\text { B: } \\
\text { C: } \\
\text { D: } \\
\text { E: }\end{array}$ \\
\hline $39 a$ & Long-term land use characteristics: & $\begin{array}{l}\text { A: } \\
\text { B: } \\
\text { C: } \\
\text { D: } \\
\text { E: } \\
\text { F: }\end{array}$ \\
\hline & Biotic sensitivity: & $\begin{array}{l}\text { A: } \\
\text { B: } \\
\text { C: } \\
\text { D: }\end{array}$ \\
\hline $40 \mathrm{~b}$ & Biotic damage: & $\begin{array}{l}\text { A: } \\
\text { B: } \\
\text { C: } \\
\text { D: } \\
\text { E: } \\
\text { F: }\end{array}$ \\
\hline $41 \mathrm{a}$ & Natural resource sensitivity: & $\begin{array}{l}\text { A: } \\
\text { B: } \\
\text { C: } \\
\text { D: } \\
\text { E: }\end{array}$ \\
\hline $41 b$ & Natural resource damage: & $\begin{array}{l}\text { A: } \\
\text { B: } \\
\text { C: } \\
\text { D: } \\
\text { E: } \\
\text { F: }\end{array}$ \\
\hline
\end{tabular}


APPENDIX B:

CONSTRUCTED SCALES FOR USE IN THE RESOURCE ALLOCATION SUPPORT SYSTEM 


\section{APPENDIX B:}

\section{CONSTRUCTED SCALES FOR USE IN THE RESOURCE ALLOCATION SUPPORT SYSTEM}

\section{TABLE B.1 Constructed Scale for Compliance ${ }^{a}$}

Scale
Level

A Full compliance

B Nonconformity with a U.S. Department of Energy (DOE) reference standard or other established "good practice" guidance

C Delay in meeting a Tiger Team milestone

D Violation of a standard that is mandatory under DOE policy or violation of a provision of a DOE order involving a standard that is mandatory under a DOE policy

E Request for an accommodation in complying with a statutory requirement that leads to a negotiated agreement for a compliance schedule

F Dispute in a Tri-Party Agreement that leads to work stoppage

G Dispute in a Tri-Party Agreement or Native American treaty that leads to litigation

$\mathrm{H}$ Request for an accommodation in complying with a statutory requirement that is refused and leads to a shutdown of certain operations

a Letters denote level of severity from low (A) to high (H); use with line 15 of form 2. 
TABLE B.2 Air and Water Morbidity Code: Constructed Scale for Public Safety and Health Morbidity Effects Due to Air and Water Exposure Pathways"

\begin{tabular}{cc}
\hline $\begin{array}{c}\text { Scale } \\
\text { Level }\end{array}$ & $\begin{array}{c}\text { Expected Number } \\
\text { of Sicknesses } \\
\text { or Injuries }\end{array}$ \\
\hline A & 0 \\
B & $>0$ to 1 \\
C & $>1$ to 10 \\
D & $>10$ to 100 \\
E & $>100$ \\
\hline
\end{tabular}

a Letters denote level of severity from low (A) to high (E); use with line 16 of form 2.

TABLE B.3 Air and Water Mortality Code: Constructed Scale for Public Safety and Health Mortality Effects Due to Air and Water Exposure Pathways

\begin{tabular}{cc}
\hline $\begin{array}{c}\text { Scale } \\
\text { Level }\end{array}$ & $\begin{array}{c}\text { Expected Number } \\
\text { of Fatalities }\end{array}$ \\
\hline A & 0 \\
B & $>0$ to 1 \\
C & $>1$ to 10 \\
D & $>10$ to 100 \\
E & $>100$ \\
\hline
\end{tabular}

a Letters denote level of severity from low (A) to high (E); use with line 17 of form 2. 


\section{TABLE B.4 Risk to Future Generations: Type of Waste Left On-site}

\begin{tabular}{cl}
\hline $\begin{array}{c}\text { Scale } \\
\text { Level }\end{array}$ & \multicolumn{1}{c}{ Description } \\
\hline A & Wastes are neither hazardous nor radioactive \\
B & Hazardous metals \\
C & Low-level radioactive wastes \\
D & Mixed wastes \\
E & High-level or transuranic wastes \\
\hline
\end{tabular}

a Letters denote level of severity from low (A) to high (E); use with line 19a of form 2.

TABLE B.5 Risk to Future Generations: Potential for Releases to the Accessible Environment over 10,000 Years ${ }^{\star}$

\begin{tabular}{cl}
$\begin{array}{c}\text { Scale } \\
\text { Level }\end{array}$ & \multicolumn{1}{c}{ Description } \\
\hline A & No potential for releases \\
B & $\begin{array}{l}\text { Very low potential for releases (comparable to repository } \\
\text { storage with favorable environmental conditions) }\end{array}$ \\
C & $\begin{array}{l}\text { Low potential for releases (comparable to monitored } \\
\text { retrievable storage with favorable environmental conditions) }\end{array}$ \\
D & $\begin{array}{l}\text { Some potential for releases (comparable to underground } \\
\text { vault storage with unfavorable environmental conditions) }\end{array}$ \\
\hline
\end{tabular}

a Letters denote level of severity from low (A) to high (D); use with line $19 \mathrm{c}$ of form 2. 
TABLE B.6 New Capacity Statug:

Constructed Scale for Estimating

Schedule Delays in Providing New

Treatment, Storage, or Dieposal Capacity

\begin{tabular}{ccccc}
\hline $\begin{array}{c}\text { Scheduled } \\
\text { Completion } \\
\text { Date }\end{array}$ & 0 & 1-6 & $7-12$ & $>12$ \\
\cline { 2 - 5 } & A & D & G & J \\
\hline Budget year & A (months) \\
Out-year 1 & A & C & F & I \\
$>$ Out-year 1 & A & B & E & H \\
\hline
\end{tabular}

- Letters denote level of severity from low (A) to high $(J)$; use with line $30 \mathrm{a}$ of form 2.

TABLE B.7 Constructed Scale for Public Concern ${ }^{a}$

Scale

Level

Description

A No public concern. No local residents express fear or mistrust about this activity. Regional activist groups do not oppose this activity. No national political or media attention is given to this activity.

B Minor public concern. A few local residents express fear and mistrust about the activity. One regional activist group opposes this activity. Very little national political or media attention is given to this activity.

C Moderate public concern. Few local residents (about 10\%) express fear and mistrust regarding this activity. Several regional activist groups oppose this activity. Minor national media coverage and some national political interest are expressed about this activity.

D High public concern. Half of the local residents express fear and mistrust regarding this activity. Most regional activist groups concerned with waste management oppose this activity. Substantial national media coverage is given to this activity, and some political activities occur that could lead to congressional action regarding this activity.

E Very high public concern. Most local residents (about 75\%) express fear and mistrust regarding this activity. All regional g-oups concerned with waste management and several other groups oppose this activity.

Frequent national media coverage occurs, and substantial national political activity, including congressional investigations, is present.

Letters denote level of concern from low (A) to high (E); use with line 36 of form 2. 
TABLE B.8 Cultural Impacto: Bignificance of the 8ite under Consideration for Preservation*

\begin{tabular}{cl}
\hline $\begin{array}{r}\text { Scale } \\
\text { Level }\end{array}$ & Description \\
\hline A & No significance \\
B & Local significance \\
C & Regional significance \\
D & National significance \\
\hline
\end{tabular}

- Letters denote level of severity from low (A) to high (D); use with line 37a of form 3.

TABIE B.9 Cultural Impacte: Damage to the Site or Interference with Site Usea

Scale

Level Description

A No damage to the site or interference with site use

B Site access restricted for 25 years, but no damage

C $50 \%$ of the site is damaged

D Site is destroyed completely or can never be used

a Letters denote level of severity from low (A) to high (D); use with line 37b of form 3. 
TABLE B.10 Short-Term Land Use: Quality of and Demand for Land*

Scale

Level

Description

A No use of or demand for the land

B Low-quality land (e.g., desert) with low demand

C Moderate-quality land (e.g., agriculture, industrial) with moderate demand (e.g., a proposal for industrial development exists)

D High-quality land (e.g., homes, recreational activities) with moderate demand (e.g., proposal for housing development or resort exists)

E High-quality land (e.g., homes, recreational activities) with high demand (e.g., Native American claims to use the land for hunting and fishing)

- Letters denote level of severity from low (A) to high (E); use with line $38 a$ of form 3.

TABLE B.11 Long-Term Land Uee: Characterictice of Waste Permanently Disposed of On-site"

\begin{tabular}{|c|c|}
\hline $\begin{array}{l}\text { Scale } \\
\text { Level }\end{array}$ & Description \\
\hline $\mathbf{A}$ & No harmful wastes \\
\hline B & Hazardous organic waste \\
\hline C & Hazardous metals \\
\hline $\mathbf{D}$ & $\begin{array}{l}\text { Mixed hazardous metals and low-level } \\
\text { radioactive wastes }\end{array}$ \\
\hline $\mathbf{E}$ & $\begin{array}{l}\text { Mixed hazardous wastes with some } \\
\text { high-level components }\end{array}$ \\
\hline $\mathbf{F}$ & Transuranic or high-level wastes \\
\hline
\end{tabular}


TABLE B.12 Blotic Impacte: Sensitivity of Blota*

\begin{tabular}{cc}
\hline $\begin{array}{l}\text { Scale } \\
\text { Level }\end{array}$ & Description \\
\hline A & Species are not sensitive, unique, or threatened/endangered \\
B & $\begin{array}{l}\text { Species are sensitive, but not unique to the area, but not } \\
\text { threatened/endangered }\end{array}$ \\
C & $\begin{array}{l}\text { Species are sensitive and unique to the area, but not } \\
\text { threatened/endangered }\end{array}$ \\
D & Species are threatened/endangered \\
\hline
\end{tabular}

- Letters denote level of severity from low (A) to high (D); use with line 40a of form 3.

TABLE B.18 Biotic Impacte: Damage to Blota*

\begin{tabular}{cl}
$\begin{array}{r}\text { Scale } \\
\text { Level }\end{array}$ & \multicolumn{1}{c}{ Description } \\
\hline A & No damage to biota \\
B & $\begin{array}{l}\text { Noise and vibration impacts only, leading to minor behavior } \\
\text { changes of some species, but no reduction of species }\end{array}$ \\
C & $\begin{array}{l}\text { Minor (5\%) reduction of species } \\
\text { D }\end{array}$ \\
E & Mignificant (25\%) reduction of species \\
F & Elimination of species or of their habitat \\
\hline
\end{tabular}

a Letters denote levels of severity from low (A) to high (F); use with line $40 \mathrm{~b}$ of form 3. 
TABLE B.14 Natural Resource Impacte: Senditivity of Natural Recource"

Scale

Lovel Description

A Not environmentally sensitive

B State-designated natural area, state-designated scenic or wild river

C Partially developed coastal barrier or federally designated scenic or wild river

D Natural preserve, national or state wildlife refuge, undeveloped coastal barrier, federal land designated for the protection of natural ecosystems

E Marine sanctuary, national park, designated federal wilderness area, national monument, national seashore recreational area, national lakeshore recreational area

- Letters denote level of severity from low (A) to high (E); use with line 41a of form 3.

TABLE B.16 Natural Resource Impacts:

Damage to Natural Resource"

\begin{tabular}{cl}
$\begin{array}{r}\text { Scale } \\
\text { Level }\end{array}$ & \multicolumn{1}{c}{ Description } \\
\hline A & No degradation of use or damage \\
B & Aesthetic degradation of use only \\
C & $\begin{array}{l}\text { Degradation of use through noise, } \\
\text { vibration, and aesthetic impacts }\end{array}$ \\
D & Minor (5\%) loss of natural resource \\
E & Significant (25\%) loss of natural resource \\
F & Major (50\%) loss of natural resource \\
\hline
\end{tabular}

a Letters denote level of severity from low (A) to high (F); use with line $41 \mathrm{~b}$ of form 3. 
APPENDIX C:

EXAMPLES OF COMPLETED RESOURCE ALLOCATION SUPPORT SYSTEM DATA FORMS AND WORKSHEETS 


\section{APPENDIX C:}

\section{EXAMPLES OF COMPLETED RESOURCE ALLOCATIONS SUPPORT SYSTEM DATA FORMS AND WORKSHEETS}

This appendix is structured in the form of a hypothetical funding unit ${ }^{1}$ at the Richland field office. This format is used to lend realism to the example and to help in filling out the forms.

The hypothetical funding unit, called the Waste Processing Module 1 (WPM1), is made up of three activities associated with processing (1) transuranic waste (TRU), (2) mixed waste, and (3) low-level waste. Each activity has three funding unit alternatives (standby, intermediate, and operations).

Nine sets of forms and worksheets are needed to give a complete description of this funding unit and its alternatives. All of the completed forms and worksheets (a total of 35 attachments) are included in this appendix.

If this funding unit had dealt with only one type of waste, only three sets of forms would have been needed. The six additional sets of forms are intended to clearly identify the amounts of each type of waste to be treated. Most of the other input data apply to the field office and could be noted on the forms and worksheets for any one of the waste types; those data are associated with the activity for treatment of TRU waste.

\section{C.1 BACKGROUND ON THE WASTE PROCESSING MODULE 1 FUNDING UNIT}

This funding unit involves the technical and support work necessary to design, construct, and operate the WPM1. This planned facility will be used to certify and treat more than 38,000 drums of suspect TRU solid waste stored at the Hanford Site, as well as wastes generated for many years after 1990. The TRU fraction of these wastes may be transported to and emplaced in the Waste Isolation Pilot Plant in New Mexico. The non-TRU fraction will be segregated for either on-site disposal or further processing. The new WPM1 facility will be located in the 200 West Area of the Hanford Site.

As shown in Table C.1, three alternatives (standby, intermediate, and operations) were considered for this funding unit. The U.S. Department of Energy (DOE) has committed to construct WPM1, which is a milestone in the Tri-Party Agreement (TPA) with the state of Washington and the U.S. Environmental Protection Agency. Until the facility is operational, requirements of the Resource Conservation and Recovery Act (RCRA) regarding

1 A hypothetical funding unit is used rather than a real funding unit to better illustrate data form and worksheet characteristics. 
TABLE C.1 Description of Funding Unit for Hanford Waste Processing Module 1

\begin{tabular}{|c|c|c|c|}
\hline Activity & Standby & Intermediate & Operations \\
\hline $\begin{array}{l}\text { Design, construct, } \\
\text { and operate } \\
\text { WPM1 to certify } \\
\text { and treat low- } \\
\text { level, mixed, and } \\
\text { transuranic } \\
\text { wastes }\end{array}$ & $\begin{array}{l}\text { - Do not construct } \\
\text { WPM1 } \\
\text { - Fines continue }\end{array}$ & $\begin{array}{l}\text { - Same as operations, } \\
\text { except construction } \\
\text { and operation } \\
\text { delayed by two years } \\
\text { - Fines are reduced } \\
\text { and eventually } \\
\text { eliminated }\end{array}$ & $\begin{array}{l}\text { Begin construction } \\
\text { of WPM1 in } 1996 \\
\text { - Meet milestone in } \\
\text { TPA for start of } \\
\text { operations }\end{array}$ \\
\hline $\begin{array}{l}\text { Laws, regulations, } \\
\text { orders, or treaties } \\
\text { with issues }\end{array}$ & $\begin{array}{l}\text { TPA regarding RCRA } \\
\text { requirements for: } \\
\text { - TSD (40 CFR 264) } \\
\text { - LDRs (40 CFR 268) }\end{array}$ & $\begin{array}{l}\text { TPA regarding RCRA } \\
\text { requirements for: } \\
\text { - TSD (40 CFR 264) } \\
\text { - LDRs (40 CFR 268) }\end{array}$ & $-{ }^{a}$ \\
\hline
\end{tabular}

a Indicates that there are no consequential compliance issues for this alternative.

treatment, storage, and disposal (TSD) facilities (40 Code of Federal Regulations [CFR] 264) and regarding land disposal restrictions (LDRs) (40 CFR 268) are not met. It is assumed that until construction begins, fines will be imposed. After construction begins, it is highly likely that no fines will be imposed.

The standby alternative does not provdie for construction, treatment of waste, or waste shipment. In the intermediate alternative, construction begins in 1998 (which reduces the likelihood that litigation will continue), and waste treatment and shipment of TRU begin in 2000. In the operations alternative, construction begins in 1996, and waste treatment and shipment of TRU begin in 1998 (two years earlier than it begins in the intermediate alternative).

\section{C.2 EXPLANATION OF ATTACHMENTS}

The remainder of this appendix consists of Table C.2 and 35 attachments (forms and worksheets). Table C.2 briefly explains the attachments.

Attachments 1-8 relate to the standby alternative, 9-23 to the intermediate alternative, and 24-35 to the operations alternative. The standby alternative was kept simple so that no worksheets would be needed. Most information about this funding unit alternative is recorded in forms for the TRU treatment activity (Attachments 1-4). Attachments 5-8 are primarily needed to record additional waste types (mixed and low level) and the level of 
scheduled operations for each of these wastes. The first worksheet (Attachment 12) is needed to describe uncertainties about compliance and public safety and health.

The intermediate alternative is more complex. It shows how to score (1) more than one compliance issue for an activity and (2) uncertainty among outcomes for several objectives. Both of the RASS worksheets, including their continuation pages, are used and explained as part of the description of the intermediate alternative. Many notes explain line entries. Users of RASS are encouraged to make liberal use of the note fields. 


\title{
TABLE C.2 Explanation of Attachments for an Example Funding Unit
}

\author{
Attachment \\ Number \\ Explanation of Attachment \\ 1 Form 1, Record ID 1.11, Standby Alternative, TRU Treatment \\ This attachment is used to specify record ID (1.11), related activity data sheet (2220-1) and \\ task description document (AA/BB), date (08/24/92), preparer (H. Wagner), preparer's \\ phone number (509-987-6543), field office (Richland), installation (Hanford), funding unit \\ name (Waste Processing Module 1), activity name (Waste Processing Module 1 - TRU), \\ alternative name (standby), waste type (TRU), activity type (treatment), facility status \\ (proposed), and a note (an explanation of the record ID number).
}

Form 2, Record ID 1.11

This attachment is used to specify scores for compliance, air and water morbidity, air and water mortality, risk to future generations, operations scheduled and met, milestones scheduled and met, new capacity status, fines, and public concern.

Because RASS does not distinguish between waste types for many of the data entries, it is not necessary to provide a complete set of scores for every activity in a funding unit. However, the scorer can provide this level of detail if he or she wishes to do so. In this example, most scores for the other two activities (which involve low-level waste and mixed waste) are included in this form for transuranic waste. The only entries in Attachment 2 that uniquely apply to transuranic waste are those in lines 26 and 27 (for operations scheduled and operations met).

line 15: The standby alternative requests no funding, which will result in a dispute in a Tri-Party Agreement regarding RCRA requirements for

- Treatment, storage, and disposal (40 CFR 264)

- Interim status (40 CFR 265)

- Land disposal regulations (40 CFR 268)

and will lead to litigation. This rating is level G (from Table B.1 in Appendix B), and it applies for 25 years.

line 16: It is estimated that morbidity (number of sicknesses or injuries) will be nonzero but small $(<1)$ for all years (level B from Table B.2) for 25 years.

line 17: It is estimated that mortality (number of deaths) will be nonzero but small $(<1)$ for all years (level B from Table B.3) for 25 years.

line 19: 600 metric tons of transuranic wastes (level $\mathrm{E}$ from Table B.4) will remain. There is some potential for releases to the accessible environment over 10,000 years, which corresponds to level D (from Table B.5).

line 25: The unit of measure for these TRU wastes is thousands of cubic feet.

line 26: $550,000 \mathrm{ft}^{3}$ of TRU are scheduled to be treated over a 25-year period beginning in fiscal year 1999 (all years specified in this example are fiscal years).

line 27: Because no waste is treated in the standby alternative, entries of $0 \%$ for percent of operations met are entered for 1999, 2000, and the 20 years following 2000.

line 28: One Headquarters-tracked milestone is scheduled in 1998 and 1999. 
Attachment

Number

Explanation of Attachment

2 Continuation of explanation of Attachment 2, Record ID 1.11

line 29: Neither of these milestones can be met in the standby alternative.

line 30a: This proposed facility is scheduled for completion more than one year in the future. The completion date will be delayed more than 12 months in the standby alternative (level $\mathrm{H}$ from Table B.6).

line 30b: The scheduled completion date is March 1, 1997.

line 32: Because no progress will be made toward completion of the facility that is specified in the Tri-Party Agreement, annual fines of $\$ 9$ million can be levied for 25 years.

line 36: Moderate public concern (level C from Table B.7) is anticipated for the standby alternative.

3

Form 2, Record ID 1.11 (cont.)

This portion of form 2 contains notes for lines 15-36.

4

Form 3, Record ID 1.11

line 37: Cultural impacts: the site is of local significance (level B from Table B.8); damage to $50 \%$ of the site (level C from Table B.9) is expected.

line 38: Short-term land use: access to 640 acres of low-quality land with low demand (level B from Table B.10) is expected to be restricted for 25 years.

line 39: Long-term land use: because the wastes will not be removed, access to 640 acres contaminated with TRU waste (level F from Table B.11) will be restricted.

line 40: No entry for this line defaults to level $A$ (the most desirable level) for the sensitivity code (Table B.12) and the damage code (Table B.13). All nonentries for constructed scales default to level A.

Form 1, Record ID 1.21, Standby Alternative, Mixed Waste Treatment

This attachment repeats most of the information in Attachment 1. The only differences involve line 1 (record ID), line 11 (waste type), and the note (that explains the record ID).

Form 2, Record ID 1.21

This attachment contains information (line 26) for scheduled mixed waste operations $\left(8,000 \mathrm{ft}^{3} / \mathrm{yr}\right.$ for 22 years beginning in 1999). In the standby alternative, no waste is processed, so $0 \%$ is entered for percent of operations met (line 27). Scores for all other measures are included in the scores for TRU waste (Attachments 2-4). 
Attachment

Number
Explanation of Attachment

7 Form 1, Record ID 1.31, Standby Alternative, Low-Level Waste Treatment

This attachment repeats most of the information in Attachment 1. The only differences involve line 1 (record ID), line 11 (waste type), and the note (which explains the record ID).

This attachment contains information (line 26) for scheduled low-level waste operations $\left(18,000 \mathrm{ft}^{3} / \mathrm{yr}\right.$ for 22 years beginning in 1999). In the standby alternative, no waste is processed, so $0 \%$ is entered for percent of operations met (line 27). Scores for all other measures are included in the scores for TRU waste (Attachments 2-4).

This attachment repeats most of the information in Attachment 1. The only differences involve line 1 (record ID), line 10 (alternative), and the note (that explains the record ID).

This form requires completing a worksheet instead of making entries in lines 15-17. The need for a worksheet is indicated by the X's in the first column for lines 15-17. The worksheet entries' (Attachment 12) are described below.

line 18: Shipment of wastes (200,000 truck-miles per year for 22 years) begin in 2001.

line 19: Line 19 has no entries because eventual treatment and shipment of all waste completely eliminates any risks to future generations in the area around the site.

line 20: Operations result in radiation exposure to workers $(20,000$ person-hours of exposure for each of 22 years beginning in 2001).

line 21: Operations result in chemical exposure to workers $(10,000$ person-hours of exposure for each of 22 years beginning in 2001).

line 22: Beginning construction in 1998 results in risks to workers.

line 23: The beginning of operations poses many risks (in addition to those from radiation and chemical exposures) to workers (50,000 person-hours for each of 22 years beginning in 2000).

line 27: Because operations begin two years after they were scheduled, they must continue at maximum capacity for 22 years.

line 29: Only one of the two milestones is met before the end of the year 2000. Even though the second milestone is eventually met, no credit is given because it is met after the year 2000. 

Attachment
Number
Explanation of Attachment

10 line 30: Because of the two-year delay in completing construction, the schedule status code is $\mathrm{H}$ (as it was for the standby alternative).

line 31: In the intermediate alternative, funds are requested for the budget year and the following 26 years. Attachment 10 is the first attachment that shows a funding request. (No funds were requested for the standby alternative.)

line 32: Because of progress on meeting the Tri-Party Agreement because of construction, fines are reduced (compared to the standby alternative) and eventually eliminated.

line 36: The magnitude of public concern is also reduced (after 1997) because of progress on meeting the Tri-Party Agreement and treating and shipping waste.

11 Form 2, Record ID 1.12 (cont.)

This attachment contains notes about lines in Attachment 10.

Worksheet 2, Record ID 1.12

This attachment is a worksheet that describes uncertainties about compliance and public safety and health.

line 15: There is uncertainty about the response of regulatory bodies to planned actions, and a chance ( 0.5 probability in 1996) that actions taken in the intermediate alternative will still result in a dispute and lead to litigation (level G). On the other hand, there is a chance ( 0.5 probability in 1996) that the regulatory body will view actions as signs of intent to achieve full compliance in the near future and treat the funding unit as if it were already in compliance (level A). As progress continues in the out-years, the probability of litigation decreases; without question, full compliance is expected to begin in 2001.

line 16: There is uncertainty about the extent of illness among the public. Air and water pathways may result in exposures to the public. A small chance exists that someone may become sick, which is represented by 0.3 probability that no one (level $A$ ) will become sick, 0.5 probability that no more than 1 person (level B) will become sick, and 0.2 probability that 1 to 10 persons (level C) will become sick. As progress continues in the out-years, the probability that no one will become sick increases. In a typical year after 2000 , the probability that no one will become sick is $\mathbf{0 . 9}$.

line 17: Although there is uncertainty about the possibility that wastes present on the site may contribute to the death of a member of the public, the funding unit manager judged it reasonable to assume that this scenario could happen (no risk assessment covers the near future to confirm or deny this possibility) and therefore assigned a probability of 1 to level B. A preliminary risk assessment based on the assumption that the wastes present are eventually treated and shipped indicates that a small possibility (in the typical year after 2000) exists that a public fatality may result from exposure via air or water pathways. The expected value of this estimate is $10^{-6}$ fatalities per year. The entries of $1-2 \times 10^{-6}$ for level $A$ and $2 \times 10^{-6}$ for level B are equivalent to $10^{-6}$ fatalities per year. 


\section{TABLE C.2 (Cont.)}

\section{Attachment \\ Number Explanation of Attachment \\ 13 Worksheet 2, Record ID 1.12 (cont.) \\ This attachment is a worksheet that describes uncertainties about public concern (line 36). \\ A note about the entries in line 36 is included on this worksheet. \\ line 36: The degree of public concern is uncertain; however, it is expected to decrease as progress continues. In 1996 , it is very likely ( 0.9 probability) that public concern will be moderate (level C). The probability of level $\mathrm{C}$ steadily decreases and eventually becomes zero (in 2000). In a typical year after 2000, there is only 1 chance in 100 that public concern will be rated as high as "minor" (level B).}

14 Form 3, Record ID 1.12

line 37: The significance of cultural impacts is represented by level B (local significance). The level of damage is uncertain and is described in Attachment 15.

line 38: The land is low quality, demand is low (level B), and 640 acres are involved. In the short term, access to this land will be restricted for 15 years (an average).

line 39: In the long term, all wastes will be treated and shipped. Therefore, no harmful wastes will remain (level $A$ ) on the site (640 acres).

$15 \quad$ Worksheet 3, Record ID 1.12

line 37b: Progress in "restoring" the land over a 27-year period is reflected by assigning 0.5 probability to damage level $B$ and 0.5 probability to level $C$, which is a better score than the $\mathbf{C}$ score for the standby alternative. Regardless of how the site is left, it has local significance.

Worksheet 3, Record ID 1.12 (cont.)

This continuation of Worksheet 3 contains a note on the probabilities in line 37b (cultural impacts damage) of Attachment 15.

This attachment repeate most of the information in Attachment 5. The only differences involve line 1 (record ID), line 10 (the alternative name), and the note (which explains the record ID).

This attachment contains estimates for mixed waste operations scheduled (line 26) and to be met (line 27) for the intermediate alternative. Beginning in 2001, the facility will operate at 100\% capacity for 22 years. Scores for all other measures are included in the scores for the intermediate TRU waste alternative (Attachments 9-15, Record ID 1.21). 
Attachment

Number

19
Explanation of Attachment

\section{Form 1, Recond ID 1.32, Intermediate Alternative, Low-Level Waste Treatment}

This attachment repeats most of the information in Attachment 7. The only differences involve line 1 (record ID), line 10 (the alternative name), and the note (which explains the record ID).

This attachment contains estimates for compliance (line 15) and low-level waste operations that are scheduled (line 26) and to be met (line 27) for the intermediate alternative.

The entries in Attachments 20-23 illustrate how to score a situation in which two separate compliance issues exist. Because they are separate issues, they must be recorded in separate forms. Scores for nonconformity with a DOE reference standard are noted and described in a second form (Attachments 22 and 23). Additional scores are entered for waste shipments, person-hours for operations, and operations scheduled and to be met for low-level waste.

line 15: Funding the intermediate alternative will result in delays in meeting a Tiger Team milestone (level C in Table B.1). This level applies to years 1996-2000. After the year 2000, full compliance will be achieved (level A in Table B.1).

Lines 26-27: Although 18,000 $\mathrm{ft}^{3}$ of low-level waste is scheduled to be treated each year for 22 years, the start of operations is delayed by 2 years in the intermediate alternative. Because the plant will operate at full capacity at all times, it will still take 22 years to treat and ship all of the waste.

Form 2, Record ID 1.32 (cont.)

This continuation sheet contains notes about lines in Attachment 20.

\section{Form 2, Record ID 1.32 (cont.)}

This second Form 2 is needed to record the scores for a second compliance issue that relates to a nonconformity with a DOE reference standard. This nonconformity (level B in Table B.1) will persist for 5 years beginning in 1996. Beyond 2000, it is expected that full compliance (level A) will be met with respect to this reference standard.

This continuation sheet contains a note on the compliance scores entered in line 15 of Attachment 22. 


\section{TABLS C.2 (Cont.)}

Attachment

Number

Explanation of Attachment

24

Form 1, Recond ID 1.13, Operations Alternative, TRU Waste Theatment

This attachment repeats most of the information in Attachment 9. The only differences involve line 1 (record ID), line 10 (alternative), and the note (which explains the record ID).

Form 2, Record ID 1.13

This form requires completing a worksheet instead of making ontries in lines 16-17. The need for a worksheet is indicatod by the X's in the first column for lines 16-17. The worksheet entries are described in Attachment 27.

line 18: Shipment of wastes (200,000 truck-miles per yoar for 22 years) begin in 1999 (on schedule and 2 years earlier than in the intermediato alternative.)

Line 19: No entries are needed in line 19 because eventual treatment and shipment of all wante completely eliminates any risks to future generations in the area around the site.

lime 20: The beginning of operations results in radiation exposure to workers (20,000 perwon-hours of exposure for each of 22 years beginning in 1999).

line 21: The beginning of operations results in chemical exposure to workers (20,000 person-hours of exposure for each of 22 years beginning in 1999).

line 22: The beginning of construction in 1986 results in risks to workers.

line 23: The beginning of operations poses many risks (in addition to those from radiation and chemical exposures) to workers (50,000 person-hours for each of 22 years beginning in 1999).

line 27: Operations begin as scheduled in 1999 and continue at maximum capacity for 22 years.

line 29: Both Headquarters-tracked milestones are to be met as scheduled.

line 30: Because construction proceeds on schedule, the schedule status code is $\mathbf{A}$.

line 31: Funds are requested for the budget year and the following 24 years.

line 32: Because of progress on the Tri-Party Agreement because of on-schedule construction, fines are reduced (compared to the intermediate alternative) in years 1996-1998 and eliminated by 1999.

line 36: The magnitude of public concern is lower than anticipatod in the intermediate alternative because of meeting the Tri-Party Agreement and treating and shipping waste as scheduled. The level of concern becomes level $A$ in 1999 (two years earlier than for the intermediate alternative). 


\section{TABLE C.2 (Cont.)}

\begin{tabular}{l}
$\begin{array}{c}\text { Attachment } \\
\text { Number }\end{array} \quad$ Explanation of Attachment \\
\hline
\end{tabular}

This attachment contains notes about lines in Attachment 26.

This attachment is a workeheet that describes uncertainties about compliance and public safety and health.

line 15: There is uncertwinty about the response of regulatory bodies to planned actions. There is a chance ( 0.25 probability in 1996) that actions taken in the operations alternative will still result in a dispute and lead to litigation (level G). On the other hand, there is a chance $(0.75$ probability in 1996$)$ that the regulatory body will view actions as signs of intent to achieve full compliance in the near future and treat the funding unit as if it were already in compliance (level A). As progress continues in the out-years, the probability of litigation decreases; full compliance is expected to begin in 1999.

line 16: There is uncertainty about the extent of illness among the public. Air and water pathways may result in exposures to the public, and a small chance (through the year 2000 ) exists that someone may become sick. This chance is represented by 0.3 probability that no one (level $A$ ) will become sick, 0.5 probability that no more than 1 person (level B) will become sick, and 0.2 probability that 1 to 10 persons (level C) will become sick. (These probabilities are the same as in the intermediate alternative.) However, because progress is made sooner (compared to the intermediate altornative), there is a total of 25 years of impacts (compared to 27 years for the intermediate alternative).

line 17: Although there is uncertainty about the possibility that wastes present on the site may contribute the desth of a member of the public, the funding unit manager judged it reasonable to assume that this scenario could happen (there is no risk assessment covering the near future to confirm or deny this possibility) and therefore assigned a probability of 1 to level B. A preliminary risk assessment based on the assumption that the wastes present are eventually treated and shipped indicates that a small possibility (in the typical year after 2000) exists that a public fatality may result from exposure via air or water pathways. The expected value of this estimate is $10^{-6}$ fatalities per year. The entries of $1-2 \times 10^{-6}$ for level $A$ and $2 \times 10^{-6}$ for level $B$ are equivalent to $10^{-6}$ fatalities per year.

This continuation of Worksheet 2 is used to record (1) outcome probabilities for the public concern objective (line 36) and (2) notes on lines 16, 16, 17, and 36.

line 36: The degree of public concern is also uncertain; however, it is expected to decrease as progress on construction and Tri-Party Agreements continues. In 1996, it is likely ( 0.8 probability) that public concern will be moderate (level $\mathrm{C}$ ). The probability of level $\mathrm{C}$ sharply decreases in 1997 and becomes zero in 1998. In a typical year after 2000, there is only 1 chance in 100 that public concern will be rated as high as "minor" (level B). 
Attachment

Number

Explanation of Attachment

29

Form 3, Record ID 1.13

Line 37: The significance of cultural impacts is represented by level B (local significance). The level of damage is uncertain and is described in Attachment 30.

line 38: The land is low quality and demand is low (level B); 640 acres are involved. In the short term, access to this land will be restricted for 13 years (compared to 13.5 years in the intermediate alternative).

line 39: In the long term, all wastes will be treated and shipped. Therefore, no harmful wastes will remain (lovel $A$ ) on the site (640 acrea).

There are three notes (in lines 37, 38, and 39).

30

Workaheet 3, Record ID 1.13

One workeheet is needed to record probabilities for the cultural impacts damage code. No other scores are recorded in this form.

Line 37b: Progress in "reatoring" the land over a 27-year period is reflected by assigning 0.76 probability to damage level $B$ and 0.25 probability to level $C$, which is a better score than the $\mathrm{C}$ score for the intermediate alternative. Regardless of when or how the site is left, it has local significance.

31

Worksheet 3, Record ID 1.13 (cont.)

This continuation of Worksheet 3 contains a note on the probabilities in line 37b (cultural impact damage) in Attachment 30.

This attachment repeats most of the information in Attachment 17. The only differences involve line 1 (record ID), line 10 (alternative), and the note (which explains the record ID).

This attachment contains estimates for mixed waste operations scheduled (line 26) and to be met (line 27) for the operations alternative. As scheduled in 1999, the facility will operate at $100 \%$ capacity for 22 years. Scores for all other measures are included in the scores for the TRU waste operations alternative (Attachments 24-31, Record ID 1.13). 


\section{TABLE C.2 (Cont.)}

\begin{tabular}{ll}
$\begin{array}{c}\text { Attachment } \\
\text { Number }\end{array}$ & \multicolumn{1}{c}{ Explanation of Attachment } \\
\hline 34 & $\begin{array}{l}\text { Form 1, Record ID 1.33, Operations Alternative, Low-Level Waste Treatment } \\
\text { This attachment repeato most of the information in Attachment 19. The only differences } \\
\text { involve line } 1 \text { (record ID), line } 10 \text { (alternative), and the note (which explains the } \\
\text { record ID). }\end{array}$ \\
\hline 35 & $\begin{array}{l}\text { Form 2, Record ID 1.33 } \\
\text { This attachment contains estimates for low-level waste operations scheduled (line 26) and } \\
\text { to be met (line 27) for the operations alternative. As scheduled in 1999, the facility will } \\
\text { operate at 100\% capacity for 22 years. Scores for all other measures are included in the } \\
\text { scores for the TRU waste operations alternative (Attachments 24-31, Record ID 1.13). }\end{array}$ \\
\hline
\end{tabular}




\section{Attachment 1 \\ RASS Activities: Form 1}

1

2

3

4

5

6

7 Installation name:

8 Funding unit name:

9

10

11

13

14
Record ID: $\quad l l l$

ADS/TDD: ADS: 2220-1: TDD: AAVAB

Date: $\quad 08 / 24 / 92$

Preparer: $H$. Wagner

Phone: (502) 987.6543

Field office: $\square$ AL Albuquerque $\square$ ID Idaho $R$ RL Richland

(check one) $\square \mathrm{CH}$ Chicago $\square$ NV Nevada $\square$ SF San Francisco

$\square$ FS Fernald $\square$ OR Oak Ridge $\square$ SR Savannah River

\section{Hanford}

Waste Processing Module 1

Waste Processing Module 1-TRU

Standby

$\begin{array}{lll}\text { Waste type: } & \square \text { TRU } & \square \text { Mixed } \\ \text { (check one) } & \square \text { HLW } & \square \text { Sanitary } \\ & \square \text { LLW } & \square \text { Industrial wastewater } \\ & \square \text { Hazardous } & \square \text { Other: }\end{array}$

Activity type: $\square$ Treatment $\square$ Storage

(check one) $\square$ Disposal $\square$ Transportation

$\square$ Other:

\section{Facility status: Droposed}

(check one) $\square$ Existing

4 Notes: line 1: record ID 1.11 denotes funding unit 1, activity 1 , altemative 1 


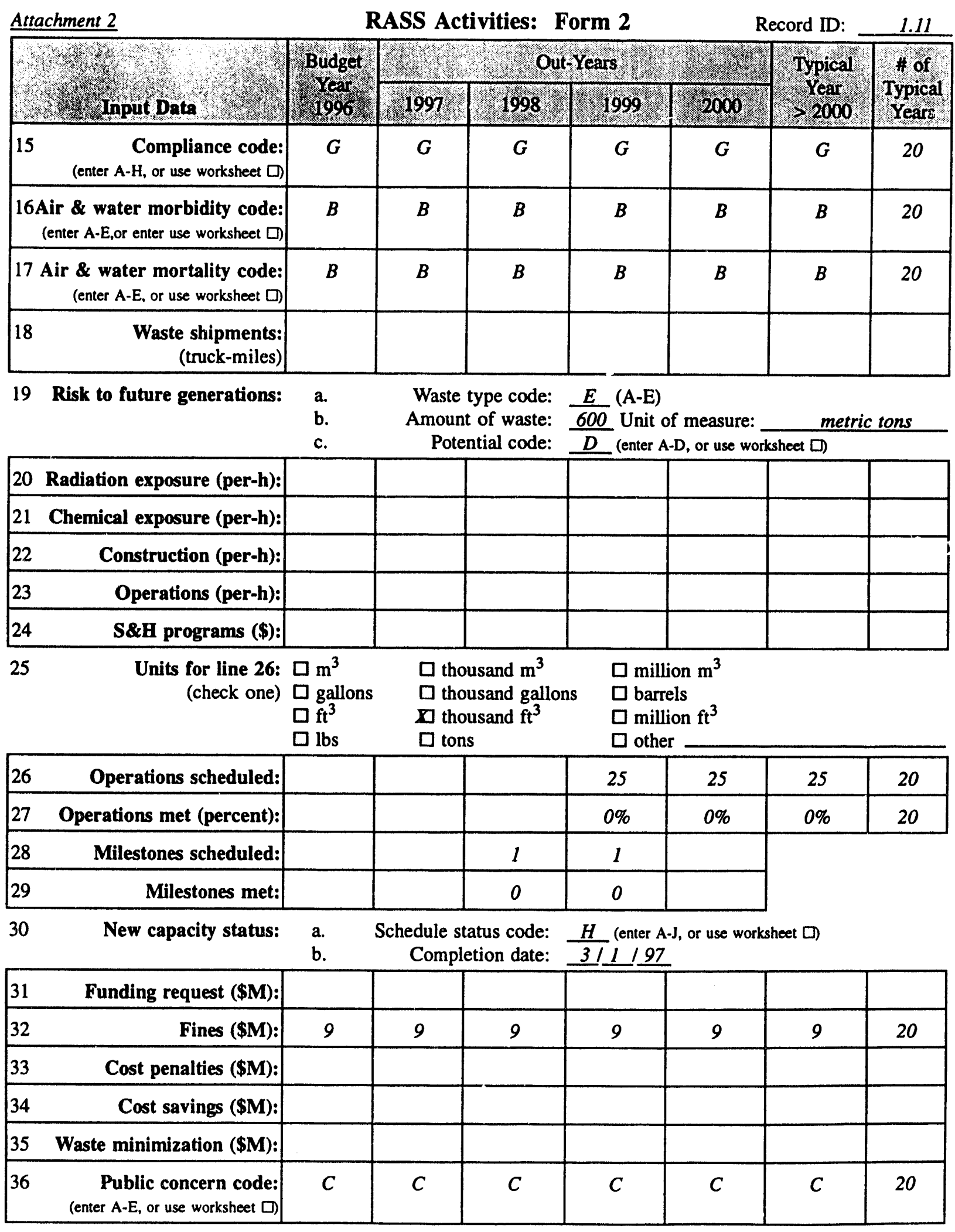


Notes: line 15: The standby alternative requests no funding, which results in a dispute in a Tri-Party Agreement regarding RCRA requirements for:

. Treatment, storage, and disposal (40 CFR 264)

- Interim status (40 CFR 265)

- Land disposal regulations (40 CFR 268)

and will lead to litigation. This is level G (Table B.1), and it applies for 25 years.

line 16: Estimated morbidity (number of sicknesses or injuries) is nonzero but small (<1) for all years. This is level B (Table B.2) for 25 years.

line 17: Estimated mortality (number of deaths) is nonzero but small $(<1)$ for all years. This is level B (Table B.3) for 25 years.

line 19: Transuranic waste ( 600 metric tons) is not treated and therefore not shipped. This poses some potential for releases to the accessible environment over 10,000 years (level D in Table B.5).

line 26: $550,000 \mathrm{ft}^{3}$ of TRU is schedulet to be treated over a 27-year period beginning in 1999.

line 27: Since no waste is treated in the standby alternative, entries of $0 \%$ for operations met are entered for 1999, 2000, and the following 20 years.

line 28: One Headquarters-tracked milestone is scheduled in 1998 and 1999.

line 29: Neither of these milestones can be met in the standby alternative.

line 30a: This is a proposed facility scheduled for completion more than one year in the future. The completion date will be delayed more than 12 months in the standby alternative. This is represented by level $H$ (Table B.6).

line 30b: Tive scheduled completion date is March 1, 1997.

line 32: Because no progress will be made toward completion of the facility that is specified in the Tri-Party Agreement, annual fines of $\$ 9$ million can be levied for 25 years.

line 36: Moderate public concern (level C in Table B.7) is anticipated for the standby alternative. 
RASS Activities: Form 3

Record ID: 1.11

\begin{tabular}{|c|c|c|c|c|}
\hline \multicolumn{2}{|r|}{ Inpur Datr. } & \multicolumn{3}{|c|}{ socores. } \\
\hline 37 & Cultural impacts: & $\begin{array}{l}\text { a } \\
\text { b }\end{array}$ & $\begin{array}{r}\text { Significance code: } \\
\text { Damage code: } \frac{B}{C}\end{array}$ & $\begin{array}{l}\text { (enter A-D, or use worksheet } \square \text { ) } \\
\text { (enter A-D, or use worksheet } \square \text { ) }\end{array}$ \\
\hline 38 & Short-term land use: & $\begin{array}{l}a \\
b \\
c\end{array}$ & $\begin{array}{r}\text { Quality and demand code: } \\
\text { Time of restriction: } \frac{B}{25} \\
\text { Amount of land: } \underline{640}\end{array}$ & $\begin{array}{l}\text { (enter A-E, or use worksheet } \square \text { ) } \\
\text { (years) } \\
\text { (acres) }\end{array}$ \\
\hline 39 & Long-term land use: & $\begin{array}{l}\text { a } \\
\mathbf{b}\end{array}$ & $\begin{array}{l}\text { Characteristics code: } \frac{F}{\text { Amount of land: } 640}\end{array}$ & $\begin{array}{l}\text { (enter A-F, or use worksheet } \square \text { ) } \\
\text { (acres) }\end{array}$ \\
\hline 40 & Biotic impacts: & $\begin{array}{l}\mathbf{a} \\
\mathbf{b}\end{array}$ & $\begin{array}{l}\text { Sensitivity code: } \\
\text { Damage code: }\end{array}$ & $\begin{array}{l}\text { (enter A-D, or use worksheet } \square \text { ) } \\
\text { (enter A-F, or use worksheet } \square \text { ) }\end{array}$ \\
\hline 41 & ural resource impacts: & $\begin{array}{l}a \\
b\end{array}$ & $\begin{array}{l}\text { Sensitivity code: } \\
\text { Damage code: }\end{array}$ & $\begin{array}{l}\text { (enter A-E, or use worksheet } \square \text { ) } \\
\text { (enter A-F, or use worksheet } \square \text { ) }\end{array}$ \\
\hline
\end{tabular}

Notes: line 37: Cultural impacts: damage to 50\% of the site (level C in Table B.9) is expected; the site is of local significance (level B in Table B.8).

line 38: Short-term land use: access to 640 acres of low-quality land with low demand (level $B$ in Table B.10) is expected to be restricted for 25 years.

line 39: Long-term land use: since the wastes will not be removed, access to 640 acres contaminated with TRU waste (level $F$ in Table B.11) will be restricted.

line 40: No entry for this line defaults to level $A$ (the most desirable level) for the sensitivity code (Table B.12) and the damage code (Table B.13). All nonentries for constructed scales default to level $A$. 
1

2

3

4

5

6

9

10

11

12 Activity type: $\quad$ Treatment

$$
\begin{aligned}
\text { Record ID: } & \frac{1.21}{\text { ADS/TDD: }} \\
\text { Date: } & \frac{A D S: 2220-1 ; T D D: A A / A B}{08 / 24 / 92} \\
\text { Preparer: } & \text { H. Wagner } \\
\text { Phone: } & \text { (509) } 987-6543
\end{aligned}
$$

Field office: $\square \mathrm{AL}^{\prime}$ Albuquerque (check one)
$\square \mathrm{CH}$ Chicago
$\square$ FS Fernald
$\square$ HQ Headquarters
IID Idaho
$\square$ NV Nevada
$\square$ OR Oak Ridge
$\square$ RF Rocky Flats

Q RL Richland

$\square$ SF San Francisco

$\square$ SR Savannah River

7 Installation name: Hanford

8 Funding unit name: Waste Processing Module 1

Activity name: Waste Processing Module 1-Mixed

0 Alternative name: Standby

Waste type: $\square$ TRU

(check one) $\square$ HLW

Mixed

$\square$ LLW

$\square$ Sanitary

$\square$ Hazardous

$\square$ Industrial wastewater

$\square$ Other:

(check one) $\square$ Disposal

$\square$ Storage

$\square$ Transportation

$\square$ Other:

3 Facility status: $\quad$ Proposed

(check one) $\square$ Existing

Notes: line 1: record ID 1.21 denotes funding unit 1 , activity 2 , alternative 1 
RASS Activities: Form 2

Record ID: 1.21

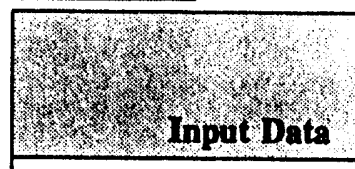

$3 \times 1$
3
3

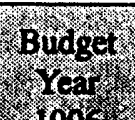

1.
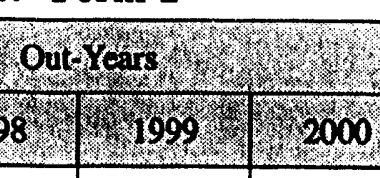

Record ID:

$\longdiv { 1 . 2 1 }$

15 Compliance code: (enter A-H, or use worksheet $\square$ )

16Air \& water morbidity code: (enter A-E,or enter use worksheet $\square$ )

17 Air \& water mortality code: (enter A-E, or use worksheet $\square$ )

Waste shipments: (truck-miles)

19 Risk to future generations:

a.

b.

1997

1998

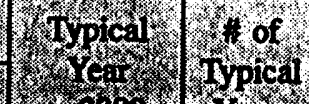

:

(1)

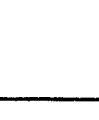

\begin{tabular}{|lr|}
\hline 20 & Radiation exposure (per-h): \\
\hline 21 & Chemical exposure (per-h): \\
\hline 22 & Construction (per-h): \\
\hline 23 & Operations (per-h): \\
\hline 24 & S\&H programs (\$): \\
\hline
\end{tabular}

25 Units for line 26: $\square \mathrm{m}^{3}$ (check one) $\square$ gallons

$\square \mathrm{ft}^{3}$

$\square \mathrm{lbs}$

Waste type code:

Amount of waste:

(A-E)

c.

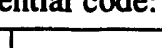

(enter A-D, or use worksheet $\square$ )

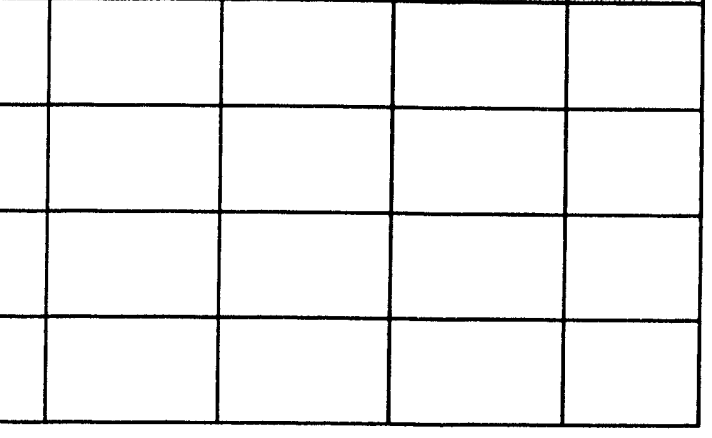

\begin{tabular}{|l|l|l|l|l|l|l|}
\hline & & & & & & \\
\hline & & & & & \\
\hline & & & & & \\
\hline
\end{tabular}
$\square$ thousand $\mathrm{m}^{3}$
$\square$ thousand gallons
$\square$ million $\mathrm{m}^{3}$
$\nabla$ thousand $\mathrm{ft}^{3}$
$\square$ barrels
$\square$ tons
$\square$ million $\mathrm{ft}^{3}$
$\square$ other

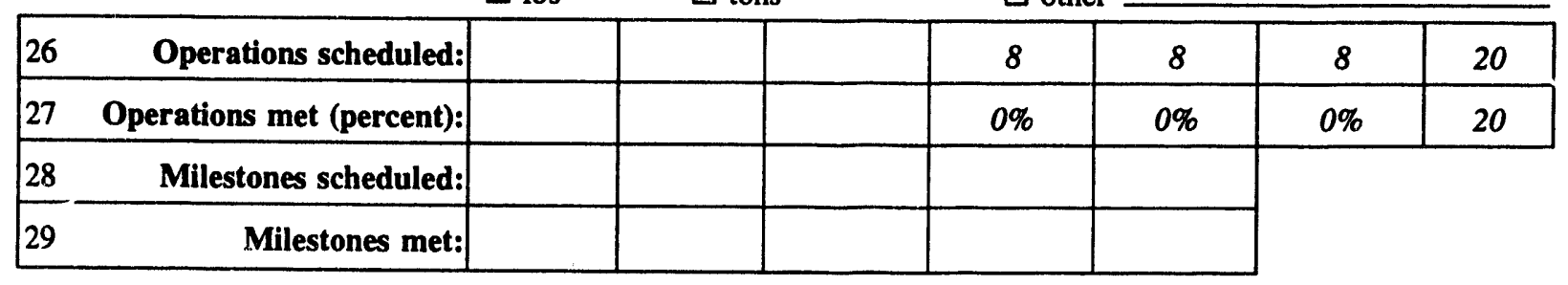

$\begin{array}{llll}30 \text { New capacity status: } & \text { a. } & \text { Schedule status code: } \\ & \text { b. } & \text { Completion date: }\end{array}$

\begin{tabular}{|r|l|l|l|l|l|l|l|}
\hline $31 \quad$ Funding request (\$M): & & & & & & & \\
\hline $32 \quad$ Fines (\$M): & & & & & & & \\
\hline $33 \quad$ Cost penalties (\$M): & & & & & & & \\
\hline $34 \quad$ Cost savings (\$M): & & & & & & & \\
\hline $35 \quad$ Waste minimization (\$M): & & & & & & & \\
\hline $36 \quad \begin{array}{r}\text { Public concern code: } \\
\text { (enter A-E, or use worksheet } \square\end{array}$ & & & & & & & \\
\hline
\end{tabular}




\begin{tabular}{|c|c|c|c|c|c|}
\hline 1 & Record ID: & 1.31 & & & \\
\hline 2 & ADS/TDD: & $A D S: 2220-1: T D D: A$ & $A \angle A B$ & & \\
\hline 3 & Date: & 08124192 & & & \\
\hline 4 & Preparer: & H. Wagner & & & \\
\hline 5 & Phone: & $(509) 987-6543$ & & & \\
\hline 6 & $\begin{array}{l}\text { Field office: } \\
\text { (check one) }\end{array}$ & $\begin{array}{l}\square \text { AL Albuquerque } \\
\square \mathrm{CH} \text { Chicago } \\
\square \mathrm{FS} \text { Fernald } \\
\square \mathrm{HQ} \text { Headquarters }\end{array}$ & $\begin{array}{ll}\square \text { ID } & \text { Idaho } \\
\square \text { NV } & \text { Nevada } \\
\square \text { OR } & \text { Oak Ridge } \\
\square \text { RF } & \text { Rocky Flats }\end{array}$ & $\begin{array}{l}\square R L \\
\square S F \\
\square S R\end{array}$ & $\begin{array}{l}\text { Richland } \\
\text { San Francisco } \\
\text { Savannah River }\end{array}$ \\
\hline 7 & Installation name: & Hanford & & & \\
\hline 8 & Funding unit name: & Waste Processing Mod & ule 1 & & \\
\hline 9 & Activity name: & Waste Processing Mod & ule 1-Low-Level Was & & \\
\hline 10 & Alternative name: & Standby & & & \\
\hline 11 & $\begin{array}{l}\text { Waste type: } \\
\text { (check one) }\end{array}$ & $\begin{array}{l}\square \text { TRU } \\
\square \text { HLW } \\
\text { DLLW } \\
\square \text { Hazardous }\end{array}$ & $\begin{array}{l}\square \text { Mixed } \\
\square \text { Sanitary } \\
\square \text { Industrial wastewa } \\
\square \text { Other: }\end{array}$ & & \\
\hline 12 & $\begin{array}{r}\text { Activity type: } \\
\text { (check one) }\end{array}$ & $\begin{array}{l}\text { Q Treatment } \\
\square \text { Disposal }\end{array}$ & $\begin{array}{l}\square \text { Storage } \\
\square \text { Transportation } \\
\square \text { Other: }\end{array}$ & & \\
\hline 13 & $\begin{array}{r}\text { Facility status: } \\
\text { (check one) }\end{array}$ & $\begin{array}{l}\text { Proposed } \\
\square \text { Existing }\end{array}$ & & & \\
\hline 14 & Notes: & line 1: record ID 1.3 & denotes funding unit & activit & 3, alternative 1 \\
\hline
\end{tabular}




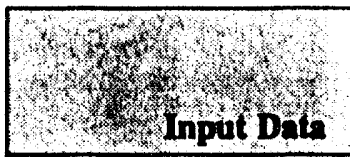

$3+x^{2}$

Compliance code:

$\begin{array}{r}\text { (enter } A-H \text {, or use worksheet } \square \text { ) } \\ \hline \text { 16Air \& water morbidity code: }\end{array}$

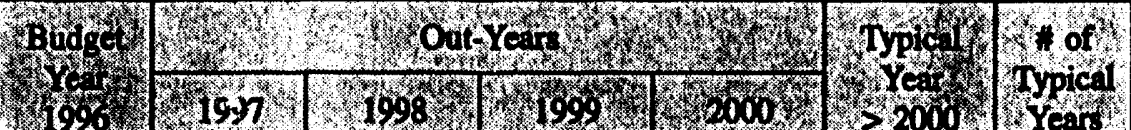
(enter A-E,or enter use worksheet $\square$ )

17 Air \& water mortality code: (enter A-E, or use worksheet $\square$ ) $18 \quad$ Waste shipments: (truck-miles)

19 Risk to future generations:

a.

b.

c.

\begin{tabular}{|lr|}
\hline 20 & Radiation exposure (per-h): \\
\hline 21 & Chemical exposure (per-h): \\
\hline 22 & Construction (per-h): \\
\hline 23 & Operations (per-h): \\
\hline 24 & S\&H programs (\$): \\
\hline
\end{tabular}

Units for line 26: $\square \mathrm{m}^{3}$ (check one)
$\square$ gallons
$\square \mathrm{ft}^{3}$
$\square \mathrm{lbs}$
Waste type code:
Amount of waste:
Potential code:

(A-E)

Unit of measure:

(enter A-D, or use worksheet D)

\begin{tabular}{|c|c|c|c|c|c|c|c|}
\hline & (check one) & $\begin{array}{l}\square \text { gallons } \\
\square \mathrm{ft}^{3} \\
\square \mathrm{lbs}\end{array}$ & $\begin{array}{l}\square \text { thousand gallons } \\
\square \text { thousand } \mathrm{ft}^{3} \\
\square \text { tons }\end{array}$ & $\begin{array}{l}\square \\
\square \\
\square\end{array}$ & & & \\
\hline 26 & Operations scheduled: & & & 18 & 18 & 18 & 20 \\
\hline 27 & Operations met (percent): & & & $0 \%$ & $0 \%$ & $0 \%$ & 20 \\
\hline \multirow{2}{*}{$\begin{array}{l}28 \\
29 \\
\end{array}$} & Milestones scheduled: & & & & & & \\
\hline & Milestones met: & & & & & & \\
\hline 30 & New capacity status: & $\begin{array}{l}\text { a. } \\
\text { b. }\end{array}$ & $\begin{array}{l}\text { Schedule status code: } \\
\text { Completion date: }\end{array}$ & 1 & use w & & \\
\hline 31 & Funding request $(\mathbf{S M})$ : & & & & & & \\
\hline 32 & Fines $(\mathbf{S M})$ : & & & & & & \\
\hline 33 & Cost penalties (\$M): & & & & & & \\
\hline 34 & Cost savings (\$M): & & & & & & \\
\hline 35 & Waste minimization (\$M): & & & & & & \\
\hline 36 & $\begin{array}{r}\text { Public concern code: } \\
\text { (enter A-E, or use worksheet } \square \text { ) }\end{array}$ & & & & & & \\
\hline
\end{tabular}


Record ID: 1.12

2

3

4

5

6

8

9

10

11

12

13

14

11

ADS/TDD: $\quad A D S: 2220-1$ : TDD: AAAB

Date: $\quad 0824192$

Preparer: H. Wagner

Phone: (509) $287-6543$

Field office: $\square$ AL Albuquerque (check one) $\square \mathrm{CH}$ Chicago

$\square$ FS Fernald

$\square$ HQ Headquarters
Q RL Richland

$\square$ SF San Francisco

$\square$ SR Savannah River $\square$ NV Nevada $\square$ OR Oak Ridge $\square$ RF Rocky Flats

Installation name: Hanford

Funding unit name: Waste Processing Module 1

Activity name: Waste Processing Module 1-TRU Waste Treatment

Alternative name: Intermediate

Waste type: (check one)

G TRU
$\square$ HLW
$\square$ LLW
$\square$ Hazardous

$\square$ Mixed

$\square$ Sanitary

$\square$ Industrial wastewater

$\square$ Other:

2
Activity type: Treatment (check one) $\square$ Disposal

\author{
$\square$ Storage \\ $\square$ Transportation \\ $\square$ Other:
}

Facility status: 1 Proposed

(check one) $\square$ Existing

Notes: line 1: record ID 1.12 denotes funding unit 1, activity 1 , alternative 2 


\begin{tabular}{|c|c|c|c|c|c|c|c|}
\hline Attachment 10 & & RASS Act & tivities: F & orm 2 & & ecord ID: & 1.12 \\
\hline 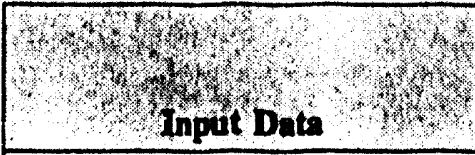 & 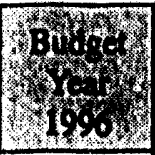 & 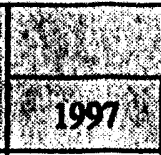 & 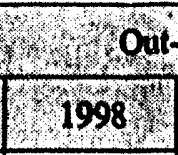 & 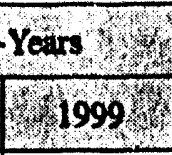 & 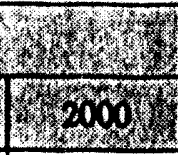 & $\begin{array}{l}\text { Typical } \\
\text { Treat }\end{array}$ & $\begin{array}{l}\text { \# of } \\
\text { Typical } \\
\text { Yoar }\end{array}$ \\
\hline $\begin{array}{l}\text { Compliance code: } \\
\text { (enter A-H, or use worksheet } \mathbf{D} \text { ) }\end{array}$ & These & are the fir & & & & & \\
\hline $\begin{array}{r}\text { 16Air \& water morbidity code: } \\
\text { (enter A-E,or enter use worksheet } \mathbf{B} \text { ) }\end{array}$ & $\begin{array}{l}\text { tores } \\
\text { to de } \\
\text { See A }\end{array}$ & $\left\{\begin{array}{l}\text { probabit } \\
\text { cribe outc } \\
\text { ttachments }\end{array}\right.$ & $\begin{array}{l}\text { pmes. } \\
11-13\end{array}$ & & & & \\
\hline $\begin{array}{r}17 \text { Air \& water mortality code: } \\
\text { (enter A-E, or use worksheet } \mathbf{D} \text { ) }\end{array}$ & for e & aboration. & & & & & \\
\hline $\begin{array}{r}\text { Waste shipments: } \\
\text { (truck-miles) }\end{array}$ & & & & & & 200,000 & 22 \\
\hline
\end{tabular}

19 Risk to future generations:

a. Waste type code:

b. Amount of waste:

c.

Potential code:

(A-E) (See note for line 19.)

Unit of measure:

(enter A-D, or use worksheet $\square$ )

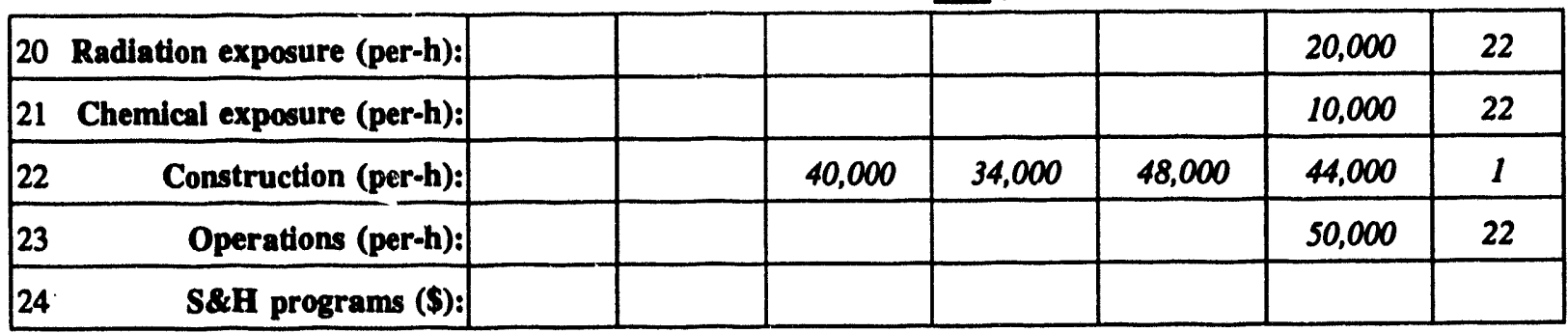

$\begin{array}{cccc}\text { Units for line 26: } & \square \mathrm{m}^{3} & \square \text { housand } \mathrm{m}^{3} & \square \text { million } \mathrm{m}^{3} \\ \text { (check one) } & \square \text { gallons } & \square \text { thousand gallons } & \square \text { barrels } \\ & \square \mathrm{ft}^{3} & \square \text { thousand } \mathrm{ft}^{3} & \square \text { million } \mathrm{ft}^{3} \\ & \square \mathrm{lbs} & \square \text { tons } & \square \text { other }\end{array}$

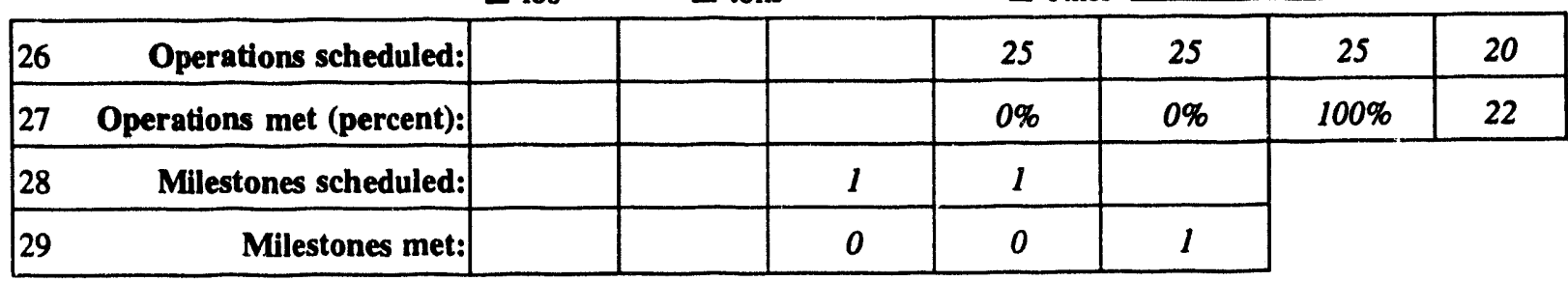

30 New capacity status: a. Schedule status code: $H$ (enter A-J, or use worksheet $\square$ )

b. Completion date: 311197

\begin{tabular}{|c|c|c|c|c|c|c|c|c|}
\hline 31 & Funding request $(\$ M)$ : & 16.2 & 20.6 & 26.1 & 28.1 & 29.6 & 31.2 & 22 \\
\hline 32 & Fines (\$M): & 4.5 & 3.6 & 2.7 & 1.8 & 0.9 & 0 & 20 \\
\hline 33 & Cost penalties (\$M): & & & & & & & \\
\hline 34 & Cost savings ( $\$ M):$ & & & & & & & \\
\hline 35 & Waste minimization (\$M): & & & & & & & \\
\hline 36 & $\begin{array}{l}\text { Pubilic concern code: } \\
\text { (enter A-E, or use worksheet } \square \text { ) }\end{array}$ & $C$ & $C$ & $B$ & $B$ & $B$ & $\boldsymbol{A}$ & 20 \\
\hline
\end{tabular}


Notes: line 15: Progress on Tri-Party Agreement continually reduces the probability of litigation (Worksheet 2 in Attachment 12). By the year 2001, there should be no possibility of litigation. These conditions also affect the size of fines entered in line 32.

line 16: As waste is treated and shipped, the risks to the public (morbidity due to exposures via air and water pathways) decrease. After 2000, the probability is small that the public safety and health might be affected - even at a low level of impact (Attachment 12).

line 17: Although there is uncertainty about the possibility that wastes present on the site may contribute to the death of a member of the public, these entries imply that it is possible. A probability of 1 was assigned to level B for years 1996-2000. Assuming that the wastes present are eventually treated and shipped, the entry for years after 2000 implies that there is a small possibility that a public fatality may result from exposure via air or water pathways. The expected value of this estimate is $10^{-6}$ fatalities per year. The entries of $1-2 \times 10^{-6}$ for level $A$ and $2 \times 10^{-6}$ for level $B$ are equivalent to $10^{-6}$ fatalities per year. (Note: These entries for a typical year after 2000 are probably not realistic - compared to those for 1996-2000 - but were chosen to illustrate how to use the constructed scale for air and water mortality to reflect a very low risk estimate.)

line 18: Shipments of treated waste begin in 2001 and continue for 22 years.

line 19: There is no entry for this line because eventual treatment and shipment of all waste completely eliminates any risks to future generations.

lines 20, 21, and 23: Operations begin in 2001 and lead to occupational risks (due to radiation exposure, chemical exposure, and routine accidents).

line 22: Construction begins in 1998 and ends in 2001.

line 27: Operations, scheduled to begin in 1999, are delayed by two years.

line 28: The first of two milestones is met in 2000. No credit is given for meeting the second milestone after the year 2000.

line 32: See note for line 15. 
Record ID: 1.12

\begin{tabular}{|c|c|c|c|c|c|c|c|c|}
\hline & \multirow[b]{2}{*}{ 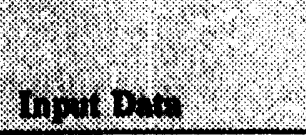 } & \multirow{2}{*}{$\begin{array}{l}\text { byon } \\
10 \%\end{array}$} & \multicolumn{4}{|c|}{$0.49 \%$} & \multirow{2}{*}{ 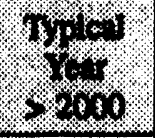 } & \multirow{2}{*}{ 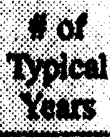 } \\
\hline & & & $10 \%$ & 198 & 199 & 2838 & & \\
\hline 15 & $\begin{array}{l}\text { Compliance code: } \\
\text { (enter probabilities) }\end{array}$ & $\begin{array}{l}\text { A:0.5 } \\
\text { B: } \\
\text { C: } \\
\text { D: } \\
\text { E: } \\
\text { F: } \\
\text { G:0.5 } \\
\text { H: }\end{array}$ & $\begin{array}{l}\text { A:0.6 } \\
\text { B: } \\
\text { C: } \\
\text { D: } \\
\text { E: } \\
\text { F: } \\
\text { G:0.4 } \\
\text { H: }\end{array}$ & $\begin{array}{l}\text { A:0.7 } \\
\text { B: } \\
\text { C: } \\
\text { D: } \\
\text { E: } \\
\text { F: } \\
\text { G:0.3 } \\
\text { H: }\end{array}$ & $\begin{array}{l}\text { A:0.8 } \\
\text { B: } \\
\text { C: } \\
\text { D: } \\
\text { E: } \\
\text { F: } \\
\text { G:0.2 } \\
\text { H: }\end{array}$ & $\begin{array}{l}\text { A:0.9 } \\
\text { B: } \\
\text { C: } \\
\text { D: } \\
\text { E: } \\
\text { F: } \\
\text { G:0.1 } \\
\text { H: }\end{array}$ & $\begin{array}{l}\text { A: I } \\
\text { B: } \\
\text { C: } \\
\text { D: } \\
\text { E: } \\
\text { F: } \\
\text { G:0 } \\
\text { H: }\end{array}$ & 22 \\
\hline & $\begin{array}{l}\text { Description of } \\
\text { compliance issue: }\end{array}$ & \multicolumn{6}{|c|}{$\begin{array}{l}\text { Progress on Tri-Party Agreement continually reduces } \\
\text { probability of litigation. }\end{array}$} & \\
\hline 16 & $\begin{array}{r}\text { Air \& water } \\
\text { morbidity code: } \\
\text { (enter probabilities) }\end{array}$ & $\begin{array}{l}\text { A:0.3 } \\
\text { B:0.5 } \\
\text { C:0.2 } \\
\text { D: } \\
\text { E: }\end{array}$ & $\begin{array}{l}\text { A:0.3 } \\
\text { B:0.5 } \\
\text { C:0.2 } \\
\text { D: } \\
\text { E: }\end{array}$ & $\begin{array}{l}\text { A:0.3 } \\
\text { B:0.5 } \\
\text { C:0.2 } \\
\text { D: } \\
\text { E: }\end{array}$ & $\begin{array}{l}\text { A:0.3 } \\
\text { B:0.5 } \\
\text { C:0.2 } \\
\text { D: } \\
\text { E: }\end{array}$ & $\begin{array}{l}\text { A:0.3 } \\
\text { B:0.5 } \\
\text { C:0.2 } \\
\text { D: } \\
\text { E: }\end{array}$ & $\begin{array}{l}\text { A:0.9 } \\
\text { B:0.1 } \\
\text { C: } \\
\text { D: } \\
\text { E: }\end{array}$ & 22 \\
\hline 17 & $\begin{array}{r}\text { Air \& water } \\
\text { mortality code: } \\
\text { (enter probabilities) }\end{array}$ & $\begin{array}{l}\text { A: } \\
\text { B: } 1 \\
\text { C: } \\
\text { D: } \\
\text { E: }\end{array}$ & $\begin{array}{l}\text { A: } \\
\text { B: } 1 \\
\text { C: } \\
\text { D: } \\
\text { E: }\end{array}$ & $\begin{array}{l}\text { A: } \\
\text { B: } 1 \\
\text { C: } \\
\text { D: } \\
\text { E: }\end{array}$ & $\begin{array}{l}\text { A: } \\
\text { B: } 1 \\
\text { C: } \\
\text { D: } \\
\text { E: }\end{array}$ & $\begin{array}{l}\text { A: } \\
\text { B: } 1 \\
\text { C: } \\
\text { D: } \\
\text { E: }\end{array}$ & $\begin{array}{l}\text { A: } 1.2 \times 10^{6} \\
\text { B: } 2 \times 10^{6} \\
\text { C: } \\
\text { D: } \\
\text { E: }\end{array}$ & 22 \\
\hline $19 \mathrm{c}$ & $\begin{array}{r}\text { Future generations } \\
\text { potential code: } \\
\text { (enter probabllities) }\end{array}$ & $\begin{array}{l}\text { A: } \\
\text { B: } \\
\text { C: } \\
\text { D: }\end{array}$ & $\begin{array}{l}\text { A: } \\
\text { B: } \\
\text { C: } \\
\text { D: }\end{array}$ & $\begin{array}{l}\text { A: } \\
\text { B: } \\
\text { C: } \\
\text { D: }\end{array}$ & $\begin{array}{l}\text { A: } \\
\text { B: } \\
\text { C: } \\
\text { D: }\end{array}$ & $\begin{array}{l}\text { A: } \\
\text { B: } \\
\text { C: } \\
\text { D: }\end{array}$ & $\begin{array}{l}\text { A: } \\
\text { B: } \\
\text { C: } \\
\text { D: }\end{array}$ & \\
\hline $30 \mathrm{a}$ & $\begin{array}{r}\text { New capacity } \\
\text { status code: } \\
\text { (enter probabilities) }\end{array}$ & $\begin{array}{l}\text { A: } \\
\text { B: } \\
\text { C: } \\
\text { D: } \\
\text { E: } \\
\text { F: } \\
\text { G: } \\
\text { H: } \\
\text { I: } \\
\text { J: }\end{array}$ & $\begin{array}{l}\text { A: } \\
\text { B: } \\
\text { C: } \\
\text { D: } \\
\text { E: } \\
\text { F: } \\
\text { G: } \\
\text { H: } \\
\text { I: } \\
\text { J: }\end{array}$ & $\begin{array}{l}\text { A: } \\
\text { B: } \\
\text { C: } \\
\text { D: } \\
\text { E: } \\
\text { F: } \\
\text { G: } \\
\text { H: } \\
\text { I: } \\
\text { J: }\end{array}$ & $\begin{array}{l}\text { A: } \\
\text { B: } \\
\text { C: } \\
\text { D: } \\
\text { E: } \\
\text { F: } \\
\text { G: } \\
\text { H: } \\
\text { I: } \\
\text { J: }\end{array}$ & $\begin{array}{l}\text { A: } \\
\text { B: } \\
\text { C: } \\
\text { D: } \\
\text { E: } \\
\text { F: } \\
\text { G: } \\
\text { H: } \\
\text { I: } \\
\text { J: }\end{array}$ & $\begin{array}{l}\text { A: } \\
\text { B: } \\
\text { C: } \\
\text { D: } \\
\text { E: } \\
\text { F: } \\
\text { G: } \\
\text { H: } \\
\text { I: } \\
\text { J: }\end{array}$ & \\
\hline
\end{tabular}


Attechment 13 RASS Activities: Worksheet 2 (Cont.)

\begin{tabular}{|c|c|c|c|c|c|c|c|c|}
\hline \multirow{3}{*}{\multicolumn{2}{|c|}{ (2) }} & \multirow{3}{*}{10} & & & & \multicolumn{2}{|c|}{ Record ID: } & \multirow{3}{*}{$\begin{array}{r}\text { of } \\
\text { Typlem }\end{array}$} \\
\hline & & & \multicolumn{4}{|c|}{ onsros } & \multirow{2}{*}{$\begin{array}{l}\text { Typleal } \\
\text { Y Yeer } \\
2000\end{array}$} & \\
\hline & & & 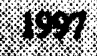 & 1804 & 193 & 43,3 & & \\
\hline 36 & $\begin{array}{l}\text { Public concern code: } \\
\text { (enter probabilities) }\end{array}$ & $\begin{array}{l}\text { A: } \\
\text { B:0.1 } \\
\text { C:0.9 } \\
\text { D: } \\
\text { E: }\end{array}$ & $\begin{array}{l}\text { A:0.1 } \\
\text { B: } 0.1 \\
\text { C:0.8 } \\
\text { D: } \\
\text { E: }\end{array}$ & $\begin{array}{l}\text { A:0.3 } \\
\text { B:0.2 } \\
\text { C:0.5 } \\
\text { D: } \\
\text { E: }\end{array}$ & $\begin{array}{l}\text { A:0.6 } \\
\text { B: } 0.2 \\
\text { C:0.2 } \\
\text { D: } \\
\text { E: }\end{array}$ & $\begin{array}{l}\text { A:0.9 } \\
\text { B:0.1 } \\
\text { C: } \\
\text { D: } \\
\text { E: }\end{array}$ & $\begin{array}{l}\text { A:0.99 } \\
\text { B:0.01 } \\
\text { C: } \\
\text { D: } \\
\text { E: }\end{array}$ & 22 \\
\hline
\end{tabular}

Notes: lines 15-17: See notes in Attachment 11.

line 36: The degree of public concern is also uncertain; however, it is expected to decrease as progress continues. In 1996, it is very likely ( 0.9 probability) that public concerm will be moderate (level $C$ ). The probability of level $C$ steadily decreases and eventually becomes zero (in 2000). In a typical year after 2000, there is only 1 chance in 100 that public concerm will be rated as high as "minor" (level B). 
Alrechment 14

RASS Activities: Form 3

Record ID: 1.12

\begin{tabular}{|c|c|c|c|c|}
\hline \multicolumn{2}{|r|}{18,20} & \multicolumn{3}{|c|}{8005} \\
\hline 37 & Cultural Impacts: & $\begin{array}{l}a \\
b\end{array}$ & $\begin{array}{l}\text { Significance code: } B \\
\text { Damage code: }\end{array}$ & $\begin{array}{l}\text { (enter A-D, or use worksheet } \square) \\
\text { (enter A-D, or use worksheet }(\Delta)\end{array}$ \\
\hline 38 & Short-term land use: & $\begin{array}{l}a \\
b \\
c\end{array}$ & $\begin{array}{l}\text { Quality and demand code: } \frac{B}{15} \\
\text { Time of restriction: } \\
\text { Amount of land: } \frac{640}{}\end{array}$ & $\begin{array}{l}\text { (eater A.E, or use worksbeet } \square \text { ) } \\
\text { (years) } \\
\text { (acres) }\end{array}$ \\
\hline 39 & Long-term land use: & $\begin{array}{l}a \\
b\end{array}$ & $\begin{array}{l}\text { Characteristics code: } \frac{A}{\text { Amount of land: } 640}\end{array}$ & $\begin{array}{l}\text { (enter A-F, or use worksheet } \square \text { ) } \\
\text { (acres) }\end{array}$ \\
\hline 40 & Biotic impacts: & $\begin{array}{l}a \\
b\end{array}$ & $\begin{array}{l}\text { Sensitivity code: } \\
\text { Damage code: }\end{array}$ & $\begin{array}{l}\text { (enter A-D, or use worksheet } \square) \\
\text { (enter } A-P \text {, or use worksheet } \square \text { ) }\end{array}$ \\
\hline & Iral resource impacts: & a & $\begin{array}{l}\text { Sensitivity code: } \\
\text { Damage code: }\end{array}$ & $\begin{array}{l}\text { (enter } A \cdot B \text {, or use worksbeet } \square) \\
\text { (enter } A \cdot P \text {, or use worksheet } \square \text { ) }\end{array}$ \\
\hline
\end{tabular}

Notes: line 37: See note in Attachment 16.

line 38: Progress in restoring the land is reflected by reducing the number of years that land use is restricted from 27 (the number of years it will take to treat and ship all of the waste) 1015 (an average, assuming an additional amount of land could be returned to use each year starting in 2001).

line 39: Because all waste is eventually treated and shipped, long-term land use is greatly improved in the intermediate alternative (compared to the standby alternative). 


\section{RASS Activities: Worksheet 3}

\begin{tabular}{|c|c|c|}
\hline \multicolumn{2}{|c|}{ Attachment 15} & 1.12 \\
\hline \multicolumn{2}{|c|}{ (2) } & 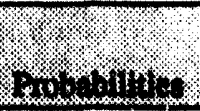 \\
\hline $37 a$ & Cultural impacts significance: & $\begin{array}{l}\text { A: } \\
\text { B: } \\
\text { C: } \\
\text { D: }\end{array}$ \\
\hline $37 \mathrm{~b}$ & Cultural impacts damage: & $\begin{array}{l}\text { A: } \\
\text { B: } 0.5 \\
\text { C: } 0.5 \\
\text { D: }\end{array}$ \\
\hline & Short-term land use quality and demand: & $\begin{array}{l}\text { A: } \\
\text { B: } \\
\text { C: } \\
\text { D: } \\
\text { E: }\end{array}$ \\
\hline $39 a$ & Long-term land use characteristics: & $\begin{array}{l}\text { A: } \\
\text { B: } \\
\text { C: } \\
\text { D: } \\
\text { E: } \\
\text { F: }\end{array}$ \\
\hline $40 a$ & Biotic sensitivity: & $\begin{array}{l}\text { A: } \\
\text { B: } \\
\text { C: } \\
\text { D: }\end{array}$ \\
\hline $40 b$ & Biotic damage: & $\begin{array}{l}\text { A: } \\
\text { B: } \\
\text { C: } \\
\text { D: } \\
\text { E: } \\
\text { F: }\end{array}$ \\
\hline $41 \mathrm{a}$ & Natural resource sensitivity: & $\begin{array}{l}\text { A: } \\
\text { B: } \\
\text { C: } \\
\text { D: } \\
\text { E: }\end{array}$ \\
\hline $41 b$ & Natural resource damage: & $\begin{array}{l}\text { A: } \\
\text { B: } \\
\text { C: } \\
\text { D: } \\
\text { E: } \\
\text { F: }\end{array}$ \\
\hline
\end{tabular}


RASS Activities: Worksheet 3 (Cont.)

Notes: line 37: Progress in "restoring" the land made over a 27-year period is reflected by assigning 0.5 probability to damage level $B$ and 0.5 probability to damage level $C$, which is a better score than the level $C$ score for the standby alternative. Regardless of how the site is left, it has local significance. 
1

2

3

4

5

6

$8 \quad$ Funding unit name:

9

10

11

12

13

14

11
Record ID: 1.22

ADS/TDD: $\quad A D S: 2220-1 ;$ TDD: $A A A A B$

Date: $\quad 08124 / 92$

Preparer: $\quad H$. Wagner

Phone: (509) 987-6543

Field office: $\square \mathrm{AL}$ Albuquerque (check one)

$\square$ FS Fernald

$\square$ HQ Headquarters

$\square$ ID Idaho

Q RL Richland

$\square$ NV Nevada

$\square$ SF San Francisco

$\square$ OR Oak Ridge

$\square$ RF Rocky Flats

7 Installation name: Hanford

Activity name: Waste Processing Module 1-Mixed Waste

10 Alternative name: Intermediate

Waste type: $\square$ TRU

(check one) $\square$ HLW

Mixed

$\square$ LLW

$\square$ Sanitary

$\square$ Industrial wastewater

$\square$ Hazardous

$\square$ Other:

Activity type: $\quad \square$ Treatment

$\square$ Storage

(check one) $\square$ Disposal

$\square$ Transportation

$\square$ Other:

$\square$ SR Savannah River

口 Other:

3 Facility status: $\square$ Proposed

(check one) $\square$ Existing

4 Notes: line 1: record ID 1.22 denotes funding unit 1, activity 2, alternative 2 
Attachment 18

RASS Activities: Form 2

Record ID: 1.22

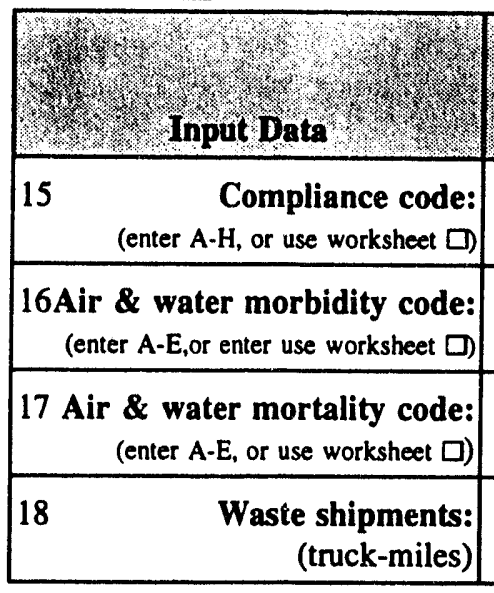

Budger
$19 \% 6$

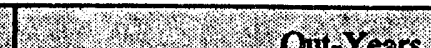

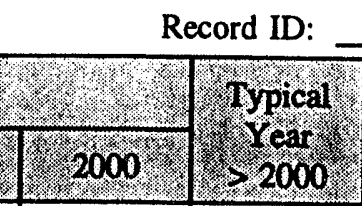

19 Risk to future generations:

a.

b.

c.
Waste type code:

Amount of waste:

Potential code:
(A-E) (See note for line 19.)

Unit of measure:

(enter A-D, or use worksheet $\square$ )

\begin{tabular}{|lr|}
\hline 20 & Radiation exposure (per-h): \\
\hline 21 & Chemical exposure (per-h): \\
\hline 22 & Construction (per-h): \\
\hline 23 & Operations (per-h): \\
\hline 24 & S\&H programs (\$): \\
\hline
\end{tabular}

Units for line 26: $\square \mathrm{m}^{3}$

(check one) $\square$ gallons

$\square \mathrm{ft}^{3}$

$\square \mathrm{lbs}$

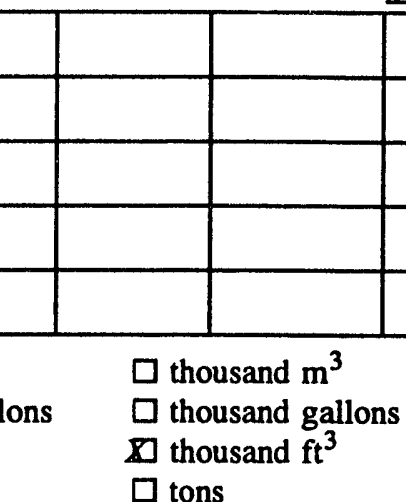

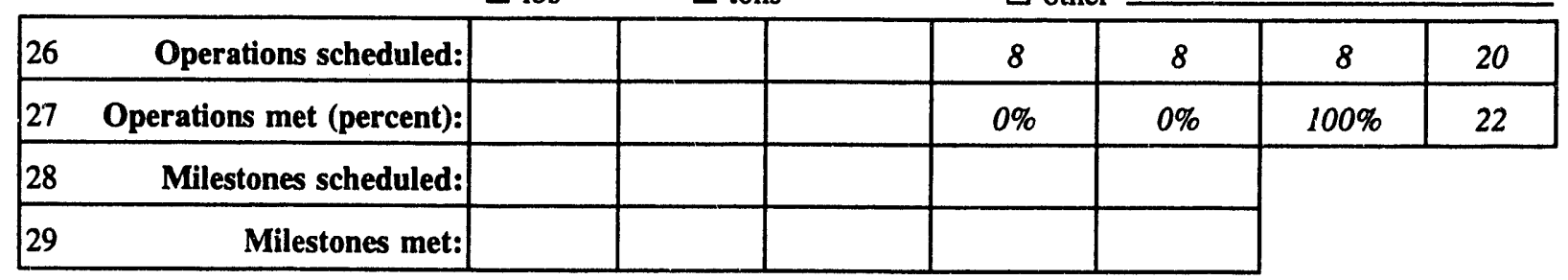

30 New capacity status:

a. Schedule status code:

(enter A-J, or use worksheet $\square$ )

b.

Completion date:

$\square$ million $\mathrm{m}^{3}$

$\square$ barrels

$\square$ million $\mathrm{ft}^{3}$

$\square$ other

\begin{tabular}{|r|l|l|l|l|l|l|l|}
\hline $31 \quad$ Funding request (\$M: & & & & & & & \\
\hline $32 \quad$ Fines $(\mathbf{\$ M}):$ & & & & & & & \\
\hline $33 \quad$ Cost penalties (\$M): & & & & & & & \\
\hline $34 \quad$ Cost savings (\$M): & & & & & & & \\
\hline $35 \quad$ Waste minimization (\$M): & & & & & & & \\
\hline $36 \quad \begin{array}{r}\text { Public concern code: } \\
\text { (enter A-E, or use worksheet } \square\end{array}$ & & & & & & & \\
\hline
\end{tabular}


1

2

3

4

5

6

7 Installation name:

8 Funding unit name:

9 Activity name:

10

11

12

13

14

\author{
Record ID: \\ 1.32 \\ ADS/TDD: $\quad A D S: 2220-1 ; T D D: A A A B$ \\ Date: $\quad 08124 / 92$ \\ Preparer: $\underline{H}$. Wagner \\ Phone: (509) 987-6543
}

Field ofíice: $\square$ AL Albuquerque (check one) $\square \mathrm{CH}$ Chicago $\square$ FS Fernald $\square$ HQ Headquarters

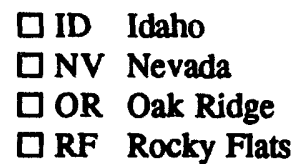

Q RL Richland

$\square$ SF San Francisco

口SR Savannah River

\section{Hanford}

Waste Processing Module 1

Waste Processing Module 1-Low-Level Waste

Alternative name: Intermediate

$\begin{array}{cll}\text { Waste type: } & \square \text { TRU } & \square \text { Mixed } \\ \text { (check one) } & \square \text { HLW } & \square \text { Sanitary } \\ & \text { 囚 LLW } & \square \text { Industrial wastewater } \\ & \square \text { Hazardous } & \square \text { Other: }\end{array}$

Activity type: $\quad \mathrm{B}$ Treatment

$\square$ Storage

$\square$ Transportation (check one) $\square$ Disposal

$\square$ Other:

\section{Facility status: 10 Proposed}

(check one) . Existing

4 Notes: line 1: record ID 1.32 denotes funding unit 1, activity 3 , alternative 2 
RASS Activities: Form 2

Record ID: 1.32

\begin{tabular}{|c|c|c|c|c|c|c|c|}
\hline 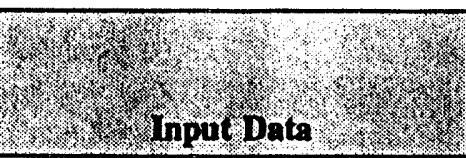 & 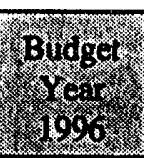 & $\frac{1997}{20}$ & $\frac{0.96}{1998}$ & $\frac{\text { Years }}{70990^{2}}$ & $\frac{(2 .)}{2000}$ & Typical & $\begin{array}{l}\# \text { of } \\
\text { Typical } \\
\text { Years }\end{array}$ \\
\hline $\begin{array}{l}\text { Compliance code: } \\
\text { (enter } A-H \text {, or use worksheet } \square \text { ) }\end{array}$ & C Delo & $\underset{\text { in }}{C}$ meeti & $\stackrel{C}{\text { g a Tiger } T}$ & $\underset{\text { am mileston }}{C}$ & $C$ & $A$ & \\
\hline \multicolumn{8}{|l|}{$\begin{array}{r}\text { 16Air \& water morbidity code: } \\
\text { (enter A-E,or enter use worksheet } \square)\end{array}$} \\
\hline \multicolumn{8}{|l|}{$\begin{array}{r}17 \text { Air \& water mortality code: } \\
\text { (enter A-E, or use worksheet } \square \text { ) }\end{array}$} \\
\hline $\begin{array}{r}\text { Waste shipments: } \\
\text { (truck-miles) }\end{array}$ & & & & & & & \\
\hline
\end{tabular}

19 Risk to future generations:

a.

Waste type code:

(A-E) (See note for line 19.)

b. Amount of waste: Unit of measure:

c. Potential code: $\quad$ (enter A-D, or use worksheet $\square$ )

\begin{tabular}{|r|l|l|l|l|l|l|l|}
\hline 20 Radiation exposure (per-h): & & & & & & & \\
\hline 21 Chemical exposure (per-h): & & & & & & & \\
\hline $22 \quad$ Construction (per-h): & & & & & & & \\
\hline $23 \quad$ Operations (per-h): & & & & & & & \\
\hline $24 \quad$ S\&H programs (\$): & & & & & & & \\
\hline
\end{tabular}

25 Units for line 26: $\square \mathrm{m}^{3}$ (check one) $\square$ gallons

$\square$ thousand $\mathrm{m}^{3}$

$\square$ million $\mathrm{m}^{3}$

$\square$ lbs

$\square$ thousand gallons

$\square$ barrels

$\nabla]$ thousand $\mathrm{ft}^{3}$

$\square$ million $\mathrm{ft}^{3}$

$\square$ tons

$\square$ other

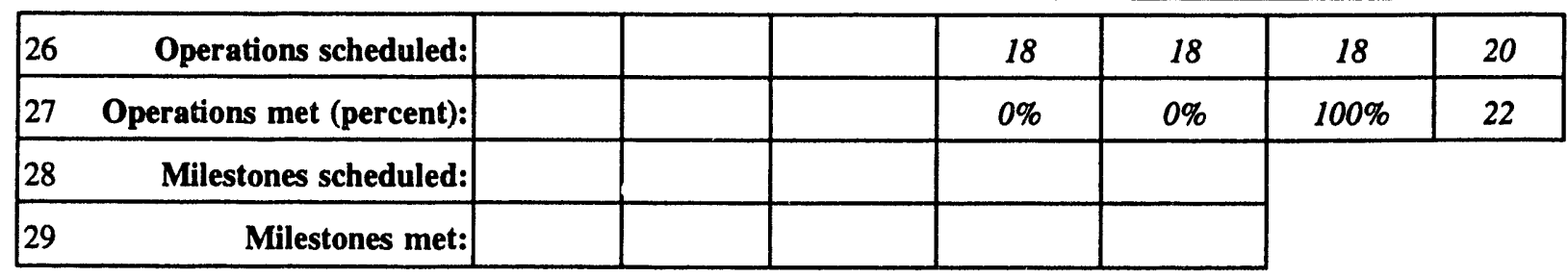
30
New capacity status:
a. Schedule status code:
(enter A-J, or use worksheet $\square$ )
b.
Completion date:

\begin{tabular}{|lr|}
\hline 31 & Funding request $(\mathbf{\$ M}):$ \\
\hline 32 & Fines $(\mathbf{M}):$ \\
\hline 33 & Cost penalties $(\mathbf{\$ M}):$ \\
\hline 34 & Cost savings $(\mathbf{\$ M}):$ \\
\hline 35 & Waste minimization $(\mathbf{M M}):$ \\
\hline 36 & $\begin{array}{r}\text { Public concern code: } \\
\text { (enter A-E, or use worksheet } \square)\end{array}$ \\
\hline
\end{tabular}

:

1 
Record ID: 1.32

Notes: line 15: These entries, in conjunction with those in the next form (Attachments 22-23), illustrate how to score a situation in which two separate compliance issues exist. Since they are separate issues, they must be recorded on separate forms. The next form addresses nonconformance with a DOE reference standard. Note that if uncertainties were present, it would be necessary to complete Worksheet 2. line 27: Percent of operations to be met estimates are entered here (they could have been entered in Attachment 22). Full operations begin in 2001 and continue for 22 years in order to process all waste. This is a two-year delay compared to the schedule. 
RASS Activities: Form 2

Record ID: 1.32

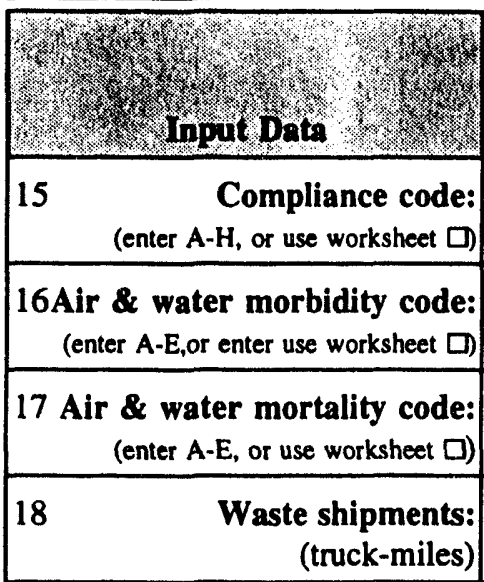

19 Risk to future generations:

\begin{tabular}{|lr|}
\hline 20 & Radiation exposure (per-h): \\
\hline 21 & Chemical exposure (per-h): \\
\hline 22 & Construction (per-h): \\
\hline 23 & Operations (per-h): \\
\hline 24 & S\&H programs (\$): \\
\hline
\end{tabular}

Units for line 26: $\square \mathrm{m}^{3}$ (check one) $\square$ gallons $\square \mathrm{ft}^{3}$ a.

b.

c.

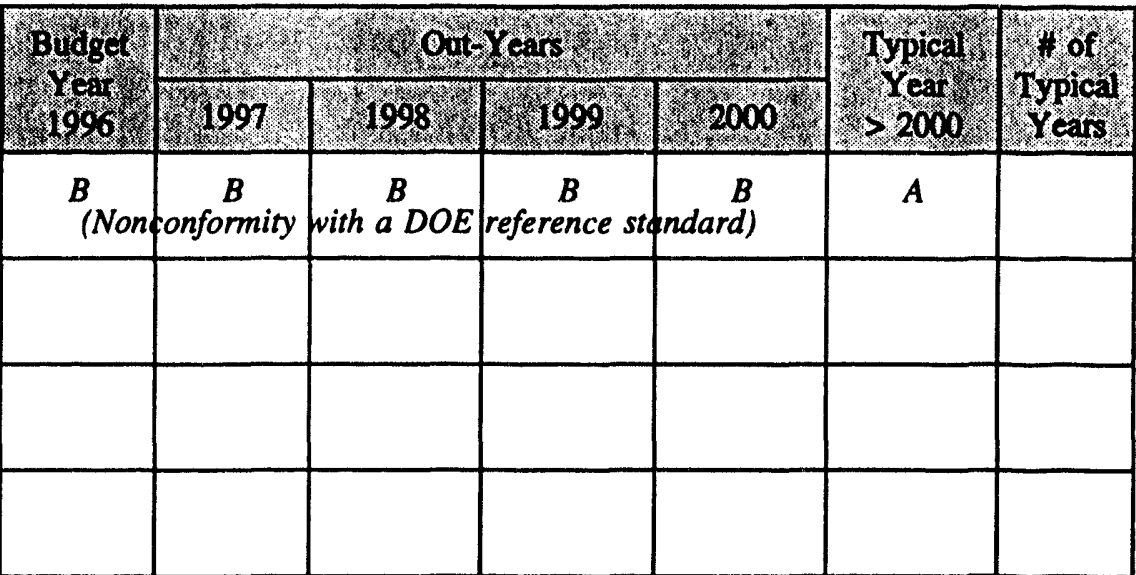

Waste type code:

Amount of waste:

Potential code:
(A-E) (See note for line 19.)

Unit of measure:

(enter A-D, or use worksheet $\square$ )

$\square$ lbs

\begin{tabular}{|l|l|l|}
\hline & & \\
\hline & & \\
\hline & & \\
\hline & & \\
\hline \\
$\square$ thousand $\mathrm{m}^{3}$ \\
$\square$ thousand gallons \\
$\square$ thousand $\mathrm{ft}^{3}$ \\
$\square$ tons
\end{tabular}

\begin{tabular}{|l|l|l|l|}
\hline & & & \\
\hline & & & \\
\hline & & & \\
\hline & & & \\
\hline
\end{tabular}

(check one)

$\square$ Ibs

\begin{tabular}{|lr|}
\hline 26 & Operations scheduled: \\
\hline 27 & Operations met (percent): \\
\hline 28 & Milestones scheduled: \\
\hline 29 & Milestones met: \\
\hline
\end{tabular}

30 New capacity status:

a. Schedule status code:

b.

$\square$ million $\mathrm{m}^{3}$

$\square$ barrels

$\square$ million $\mathrm{ft}^{3}$

$\square$ other

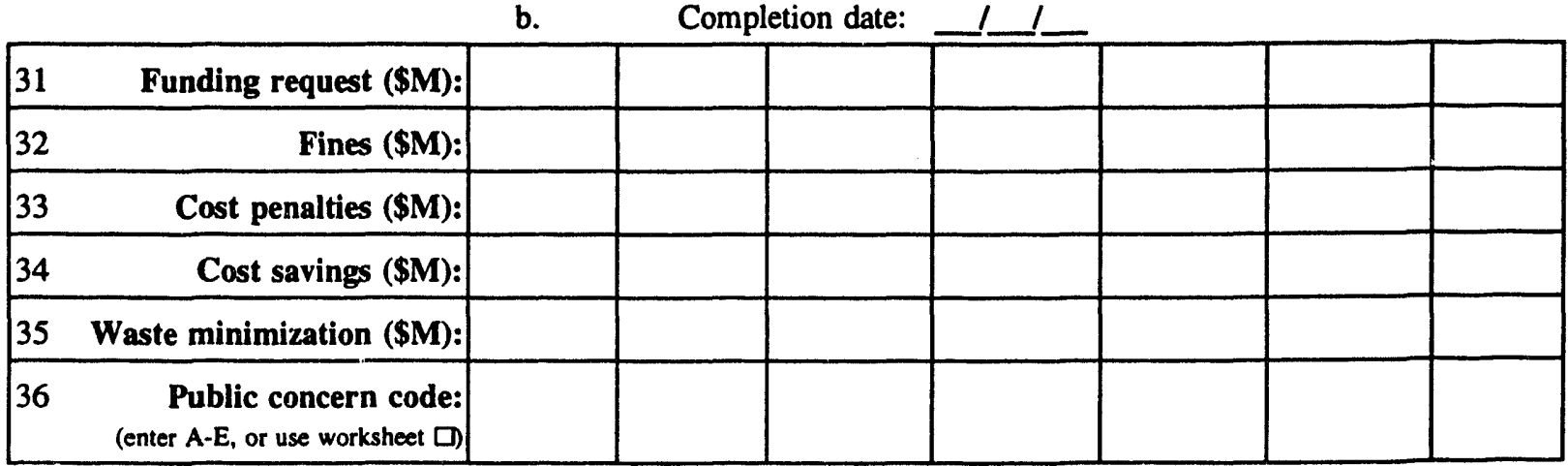


Notes: line 15: These entries, in conjunction with those in the previous form (Attachments 20-21), illustrate how to score a situation in which two separate compliance issues exist. Since they are separate issues, they must be recorded on separate forms. Attachment 20 addresses delay in meeting a Tiger Team milestone.

line 27: No entries were made here; instead, entries for percent of operations to be met were entered in Attachment 20. These entries could have been made in either place (but not both). 
1

2

3

4

5

6

Field office: (check one)

Record ID:
ADS/TDD: $\quad A D S: 2220-1 ;$ TDD: $A A V A B$

Date: $\quad 08 / 24 / 92$

Preparer: $\quad$ H. Wagner

Phone: (509)987-6543
$\square$ AL Albuquerque
$\square \mathrm{CH}$ Chicago
$\square$ FS Fernald
$\square$ HQ Headquarters
$\square$ ID Idaho
$\square$ NV Nevada
$\square$ OR Oak Ridge
$\square$ RF Rocky Flats
G RL Richland
$\square$ SF San Francisco
$\square$ SR Savannah River

7 Installation name: Hanford

8 Funding unit name: Waste Processing Module 1

9 Activity name: Waste Processing Module 1-TRU Waste

10 Alternative name: Operations

11

Waste type: TRU

(check one) $\square$ HLW

$\square$ LLW

$\square$ Hazardous

$\square$ Mixed

$\square$ Sanitary

Industrial wastewater

$\square$ Other:

12

Activity type: $\square$ Treatment

(check one) $\square$ Disposal

$\square$ Storage

$\square$ Transportation

$\square$ Other:

13 Facility status: $\quad$ O Proposed

(check one) $\square$ Existing

Notes: line 1: record ID 1.13 denotes funding unit 1, activity 1 , alternative 3 
Attachment 25

RASS Activities: Form 2

Record ID:

1.13

\begin{tabular}{|c|c|c|c|c|c|c|c|}
\hline 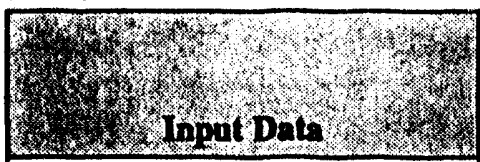 & $\begin{array}{l}\text { Budger } \\
\text { Hog }\end{array}$ & 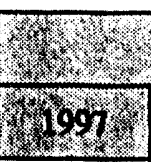 & $\frac{3.609}{1098}$ & 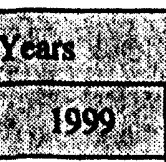 & 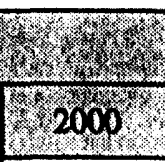 & 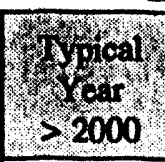 & $\begin{array}{l}\text { \# of } \\
\text { Typical } \\
\text { Years }\end{array}$ \\
\hline \begin{tabular}{|lr}
15 & $\begin{array}{c}\text { Compliance code: } \\
\text { (enter A-H, or use worksheet } \mathrm{K} \text { ) }\end{array}$
\end{tabular} & & & & & & & \\
\hline \multicolumn{8}{|l|}{$\begin{array}{r}\text { 16Air \& water morbidity code: } \\
\text { (enker A-E,or enter use worksheet } \mathbb{B} \text { ) }\end{array}$} \\
\hline \multicolumn{8}{|l|}{$\begin{array}{r}17 \text { Air \& water mortality code: } \\
\text { (enter A-E, or use worksheet } \mathbf{~} \text { ) }\end{array}$} \\
\hline $\begin{array}{r}\text { Waste shipments: } \\
\text { (truck-miles) }\end{array}$ & & & & 200,000 & 200,000 & 200,000 & 20 \\
\hline
\end{tabular}

19 Risk to future generations:

a. Waste type code:

b. Amount of waste:

(A-E) (See note for line 19.)

c.

Potential code:

Unit of measure:

(enter A-D, or use worksheet D)

\begin{tabular}{|r|r|r|r|c|c|c|c|}
\hline 20 Radiation exposure (per-h): & & & & 20,000 & 20,000 & 20,000 & 20 \\
\hline 21 Chemical exposure (per-h): & & & & 20,000 & 20,000 & 20,000 & 20 \\
\hline $22 \quad$ Construction (per-h): & 40,000 & 34,000 & 48,000 & 44,000 & & & \\
\hline $23 \quad$ Operations (per-h): & & & & 50,000 & 50,000 & 50,000 & 20 \\
\hline $24 \quad$ S\&H programs (\$): & & & & & & & \\
\hline
\end{tabular}

25 Units for line 26: $\square \mathrm{m}^{3} \quad \square$ thousand $\mathrm{m}^{3} \quad \square$ million $\mathrm{m}^{3}$

(check one) $\square$ gallons

$\square \mathrm{ft}^{3}$

$\square$ thousand gallons

DD thousand $\mathrm{ft}^{3}$

$\square$ barrels

ㅁ lbs

$\square$ tons

$\square$ million $\mathrm{ft}^{3}$

$\square$ other

\begin{tabular}{|c|c|c|c|c|c|c|c|}
\hline 26 & Operations scheduled: & & & 25 & 25 & 25 & 20 \\
\hline 27 & Operations met (percent): & ' & & $100 \%$ & $100 \%$ & $100 \%$ & 20 \\
\hline 28 & Milestones scheduled: & & 1 & 1 & & & \\
\hline 29 & Milestones met: & & 1 & 1 & & & \\
\hline
\end{tabular}

30 New capacity status: a. Schedule status code: $A$ (enter A-J, or use worksheet $\square$ )

b. Completion date: $3 / 1 / 97$

\begin{tabular}{|rr|c|c|c|c|c|c|c|}
\hline 31 & Funding request (\$M): & 23.7 & 24.4 & 25.1 & 26.5 & 30.0 & 31.2 & 20 \\
\hline 32 & Fines (\$M): & 2.7 & 1.8 & 0.9 & 0 & 0 & 0 & \\
\hline 33 & Cost penalties (\$M): & & & & & & & \\
\hline 34 & Cost savings (\$M): & & & & & & & \\
\hline 35 & Waste minimization (\$M): & & & & & & & \\
\hline $36 \quad \begin{array}{r}\text { Public concern code: } \\
\text { (enter A-E, or use workshoet } \square\end{array}$ & $C$ & $B$ & $B$ & $A$ & $A$ & $A$ & 20 \\
\hline
\end{tabular}


Record ID: 1.13

Notes: line 15: There is uncertainty about the response of regulatory bodies to planned actions. The chance that actions taken in the intermediate alternative will still result in a dispute and lead to litigation (level $G$ ) decreases as progress is made in the out-years. Full compliance is expected to begin in 1999.

line 16: There is uncertainty about the extent of illness among the public. Air and water pathways . result in exposures to the public. There is a small chance (through the year 2000) that someone may become sick (see explanation in Attachment 12; these probabilities are the same as in the intermediate alternative.) However, since progress is made sooner (compared to the intermediate alternative), there is a total of 25 years of impacts (compared to 27 years).

- line 17: Entries for 1999 and beyond are estimates of the possibility that wastes present on the site may contribute the death of a member of the public. The expected value of each estimate is $10^{-6}$ fatalities per year. The entries of $1.2 \times 10^{-6}$ for level $A$ and $2 \times 10^{-6}$ for level $B$ are equivalent to $10^{-6}$ fatalities per year.

line 18: Shipments of treated waste begin in 1999 continue for 22 years.

line 19: There is no entry for this line because eventual treatment and shipment of all waste completely eliminates any risks to future generations.

lines 20,21, and 23: Operations begin in 1999 and lead to occupational risks (due to radiation exposure, chemical exposure, and routine accidents).

line 22: Construction begins in 1996 and ends in 1999 (as scheduled).

line 27: Operations begin in 1999 (as scheduled) and continue for 22 years.

line 28: Both milestones are met on schedule.

line 32: See note for line 15. 


\begin{tabular}{|c|c|c|c|c|c|c|c|c|}
\hline & \multirow[b]{2}{*}{$(1,1,3)+3$} & \multirow{2}{*}{$10 \%$} & \multicolumn{4}{|c|}{ 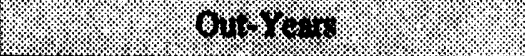 } & \multirow{2}{*}{ Tyon: } & \multirow{2}{*}{ Typled } \\
\hline & & & $198 \%$ & $19 \%$ & 89. & 2003 & & \\
\hline \multirow[t]{2}{*}{15} & $\begin{array}{r}\text { Compliance code: } \\
\text { (enter probabilities) }\end{array}$ & $\begin{array}{l}\text { A: } 0.75 \\
\text { B: } \\
\text { C: } \\
\text { D: } \\
\text { E: } \\
\text { F: } \\
\text { G: } 0.25 \\
\text { H: }\end{array}$ & $\begin{array}{l}\text { A: } 0.8 \\
\text { B: } \\
\text { C: } \\
\text { D: } \\
\text { E: } \\
\text { F: } \\
\text { G: } 0.2 \\
\text { H: }\end{array}$ & $\begin{array}{l}\text { A: } 0.9 \\
\text { B: } \\
\text { C: } \\
\text { D: } \\
\text { E: } \\
\text { F: } \\
\text { G: } 0.1 \\
\text { H: }\end{array}$ & $\begin{array}{l}\text { A: I } \\
\text { B: } \\
\text { C: } \\
\text { D: } \\
\text { E: } \\
\text { F: } \\
\text { G: } \\
\text { H: }\end{array}$ & $\begin{array}{l}\text { A: } 1 \\
\text { B: } \\
\text { C: } \\
\text { D: } \\
\text { E: } \\
\text { F: } \\
\text { G: } \\
\text { H: }\end{array}$ & $\begin{array}{l}\text { A: } 1 \\
\text { B: } \\
\text { C: } \\
\text { D: } \\
\text { E: } \\
\text { F: } \\
\text { G: } \\
\text { H: }\end{array}$ & 20 \\
\hline & $\begin{array}{r}\text { Description of } \\
\text { compliance issue: }\end{array}$ & \multicolumn{6}{|c|}{$\begin{array}{l}\text { Progress on Tri-Party Agreement continually reduces } \\
\text { probability of work stoppage (shutdown). }\end{array}$} & \\
\hline 16 & $\begin{array}{r}\text { Air \& water } \\
\text { morbidity code: } \\
\text { (enter probabilities) }\end{array}$ & $\begin{array}{l}\mathrm{A}: 0.3 \\
\mathrm{~B}: 0.5 \\
\mathrm{C}: 0.2 \\
\mathrm{D}: \\
\mathrm{E}:\end{array}$ & $\begin{array}{l}A: 0.2 \\
B: 0.5 \\
C: 0.2 \\
D: \\
E:\end{array}$ & $\begin{array}{l}\text { A:0.3 } \\
\text { B:0.5 } \\
\text { C:0.2 } \\
\text { D: } \\
\text { E: }\end{array}$ & $\begin{array}{l}\text { A:0.3 } \\
\text { B:0.5 } \\
\text { C:0.2 } \\
\text { D: } \\
\text { E: }\end{array}$ & $\begin{array}{l}\mathrm{A}: 0.3 \\
\mathrm{~B}: 0.5 \\
\mathrm{C}: 0.2 \\
\mathrm{D}: \\
\mathrm{E}: \\
\end{array}$ & $\begin{array}{l}\text { A: } 0.9 \\
\text { B: } 0.1 \\
\text { C: } \\
\text { D: } \\
\text { E: }\end{array}$ & 20 \\
\hline 17 & $\begin{array}{r}\text { Air \& water } \\
\text { mortality code: } \\
\text { (enter probabilities) }\end{array}$ & $\begin{array}{l}\text { A: } \\
\text { B: } 1 \\
\text { C: } \\
\text { D: } \\
\text { E: }\end{array}$ & $\begin{array}{l}\text { A: } \\
\text { B: } 1 \\
\text { C: } \\
\text { D: } \\
\text { E: } \\
\end{array}$ & $\begin{array}{l}\text { A: } \\
\text { B: } 1 \\
\text { C: } \\
\text { D: } \\
\text { E: } \\
\end{array}$ & $\begin{array}{l}\text { A: } 1-2 \times 10^{-6} \\
\text { B: } 2 \times 10^{-6} \\
\text { C: } \\
\text { D: } \\
\text { E: }\end{array}$ & $\begin{array}{l}\text { A: } 1.2 \times 10^{6} \\
\text { B: } 2 \times 10^{6} \\
\text { C: } \\
\text { D: } \\
\text { E: }\end{array}$ & $\begin{array}{l}\text { A: } 1-2 \times 10^{-6} \\
\text { B: } 2 \times 10^{-6} \\
\text { C: } \\
\text { D: } \\
\text { E: }\end{array}$ & 20 \\
\hline $19 c$ & $\begin{array}{r}\text { Future generations } \\
\text { potential code: } \\
\text { (enter probabilities) }\end{array}$ & $\begin{array}{l}\text { A: } \\
\text { B: } \\
\text { C: } \\
\text { D: }\end{array}$ & $\begin{array}{l}\text { A: } \\
\text { B: } \\
\text { C: } \\
\text { D: }\end{array}$ & $\begin{array}{l}\text { A: } \\
\text { B: } \\
\text { C: } \\
\text { D: }\end{array}$ & $\begin{array}{l}\text { A: } \\
\text { B: } \\
\text { C: } \\
\text { D: }\end{array}$ & $\begin{array}{l}\text { A: } \\
\text { B: } \\
\text { C: } \\
\text { D: }\end{array}$ & $\begin{array}{l}\text { A: } \\
\text { B: } \\
\text { C: } \\
\text { D: }\end{array}$ & \\
\hline $30 a$ & $\begin{array}{r}\text { New capacity } \\
\text { status code: } \\
\text { (enter probabilities) }\end{array}$ & $\begin{array}{l}\text { A: } \\
\text { B: } \\
\text { C: } \\
\text { D: } \\
\text { E: } \\
\text { F: } \\
\text { G: } \\
\text { H: } \\
\text { I: } \\
\text { J: }\end{array}$ & $\begin{array}{l}\text { A: } \\
\text { B: } \\
\text { C: } \\
\text { D: } \\
\text { E: } \\
\text { F: } \\
\text { G: } \\
\text { H: } \\
\text { I: } \\
\text { J: }\end{array}$ & $\begin{array}{l}\text { A: } \\
\text { B: } \\
\text { C: } \\
\text { D: } \\
\text { E: } \\
\text { F: } \\
\text { G: } \\
\text { H: } \\
\text { I: } \\
\text { J: }\end{array}$ & $\begin{array}{l}\text { A: } \\
\text { B: } \\
\text { C: } \\
\text { D: } \\
\text { E: } \\
\text { F: } \\
\text { G: } \\
\text { H: } \\
\text { I: } \\
\text { J: }\end{array}$ & $\begin{array}{l}\text { A: } \\
\text { B: } \\
\text { C: } \\
\text { D: } \\
\text { E: } \\
\text { F: } \\
\text { G: } \\
\text { H: } \\
\text { I: } \\
\text { J: }\end{array}$ & $\begin{array}{l}\text { A: } \\
\text { B: } \\
\text { C: } \\
\text { D: } \\
\text { E: } \\
\text { F: } \\
\text { G: } \\
\text { H: } \\
\text { I: } \\
\text { J: }\end{array}$ & \\
\hline
\end{tabular}


Record ID: 1.13

\begin{tabular}{|c|c|c|c|c|c|c|c|c|}
\hline \multirow{2}{*}{\multicolumn{2}{|c|}{ : }} & \multirow{2}{*}{ fordot. } & \multicolumn{4}{|c|}{ ourrens } & \multirow{2}{*}{$\begin{array}{l}\text { Typlcal } \\
8 \mathrm{ogn} . \\
-200\end{array}$} & \multirow{2}{*}{$\begin{array}{l}4 \text { of } \\
\text { Yolcal } \\
\text { Ycats }\end{array}$} \\
\hline & & & $199 \%$ & 1998 & 1909 & $200 \%$ & & \\
\hline 36 & $\begin{array}{l}\text { Public concern code: } \\
\text { (enter probabilitics) }\end{array}$ & $\begin{array}{l}\text { A: } \\
\text { B: } 0.2 \\
\text { C: } 0.8 \\
\text { D: } \\
\text { E: }\end{array}$ & $\begin{array}{l}\text { A:0.3 } \\
\text { B: } 0.3 \\
\text { C:0.4 } \\
\text { D: } \\
\text { E: }\end{array}$ & $\begin{array}{l}\text { A: } 0.8 \\
\text { B:0.2 } \\
\text { C: } \\
\text { D: } \\
\text { E: }\end{array}$ & $\begin{array}{l}\text { A: } 0.9 \\
\text { B: } 0.1 \\
\text { C: } \\
\text { D: } \\
\text { E: }\end{array}$ & $\begin{array}{l}\text { A: } 0.9 \\
\text { B: } 0.1 \\
\text { C: } \\
\text { D: } \\
\text { E: }\end{array}$ & $\begin{array}{l}\text { A: } 0.99 \\
\text { B: } 0.01 \\
\text { C: } \\
\text { D: } \\
\text { E: }\end{array}$ & 20 \\
\hline
\end{tabular}

Notes: line 15: There is uncertainty about the response of regulatory bodies to planned actions. The chance that actions taken in the intermediate alternative will still result in a dispute and lead to litigation (level $G$ ) decreases as progress is made in the out-years. Full compliance is expected to begin in 1999.

line 16: There is uncertainty about the extent of illness among the public. Air and water pathways may result in exposures to the public. There is a small chance (through the year 2000) that someone may become sick (see explanation in Attachment 12; these probabilities are the same as in the intermediate alternative). However, since progress is made sooner (compared to the intermediate alternative), there is a total of 25 years of impacts (compared to 27 years).

line 17: Entries for 1999 and beyond are estimates of the possibility that wastes present on the site may contribute to the death of a member of the public. The expected value of each estimate is $10^{-6}$ fatalities per year. The entries of $1.2 \times 10^{-6}$ for level $A$ and $2 \times 10^{-6}$ for level $B$ are equivalent to $10^{-6}$ fatalities per year.

line 32: Fines listed are "best estimates" and depend on the uncertainties discussed in the note for line 15.

line 30: The degree of public concern is also uncertain. However, it is expected to decrease as progress continues, and at a faster rate compared to the intermediate alternative. The probability of level A staris at 0.3 in 1996, increases to 0.9 by 1998, and is 0.99 by the year 2001. In a typical year after 2000 , there is only 1 chance in 100 that public concern will be rated as high as "minor" (level B). 


\begin{tabular}{|c|c|c|c|c|}
\hline & 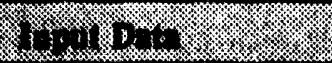 & & (2) & 10 \\
\hline 37 & Cultural impacts: & $\begin{array}{l}\mathbf{a} \\
\mathbf{b}\end{array}$ & $\begin{array}{l}\text { Significance code: } \\
\text { Damage code: }\end{array}$ & $\begin{array}{l}\text { (enter A-D, or use worksheet } \square \text { ) } \\
\text { (enter A-D, or use worksbeet }\end{array}$ \\
\hline 38 & Short-term land use: & $\begin{array}{l}\mathbf{a} \\
\mathbf{b} \\
\mathbf{c}\end{array}$ & $\begin{array}{l}\text { Quality and demand code: } \frac{B}{13} \\
\text { Time of restriction: } \\
\text { imount of land: } \frac{640}{}\end{array}$ & $\begin{array}{l}\text { (enter A-E, or use worksteet D) } \\
\text { (years) } \\
\text { (acres) }\end{array}$ \\
\hline 39 & Long-term land use: & $\begin{array}{l}\mathbf{a} \\
\mathbf{b}\end{array}$ & $\begin{array}{l}\text { Characteristics code: } A \\
\text { Amount of land: } \frac{\alpha 40}{}\end{array}$ & $\begin{array}{l}\text { (enter A-F, or use worksheet D) } \\
\text { (acres) }\end{array}$ \\
\hline 40 & Blotic impacts: & $\begin{array}{l}a \\
b\end{array}$ & $\begin{array}{l}\text { Sensitivity code: } \\
\text { Damage code: }\end{array}$ & $\begin{array}{l}\text { (enter } A \cdot D \text {, or use worksbeet } \square \text { ) } \\
\text { (enter } A-F \text {, or use worksbeet } \square \text { ) }\end{array}$ \\
\hline 41 & ral resource impacts: & $\mathbf{b}$ & $\begin{array}{l}\text { Sensitivity code: } \\
\text { Damage code: }\end{array}$ & $\begin{array}{l}\text { (enter A-E, or use worksheet } \square \text { ) } \\
\text { (enter } A-\text {, or use worksteet } \square \text { ) }\end{array}$ \\
\hline
\end{tabular}

Notes: line 37: Uncertainties about cultural impacts (damage) are recorded on Worksheet 3 (Attachment 30).

line 38: Earlier progress in restoring the land is reflected by reducing the number of years that land use is restricted from 15 (for the intermediate alternative) to 13 (an average; see explanation in Attachment 14).

line 39: Long-term land use is the same in the intermediate and operations alternatives because all waste is eventually treated and shipped in both alternatives. 

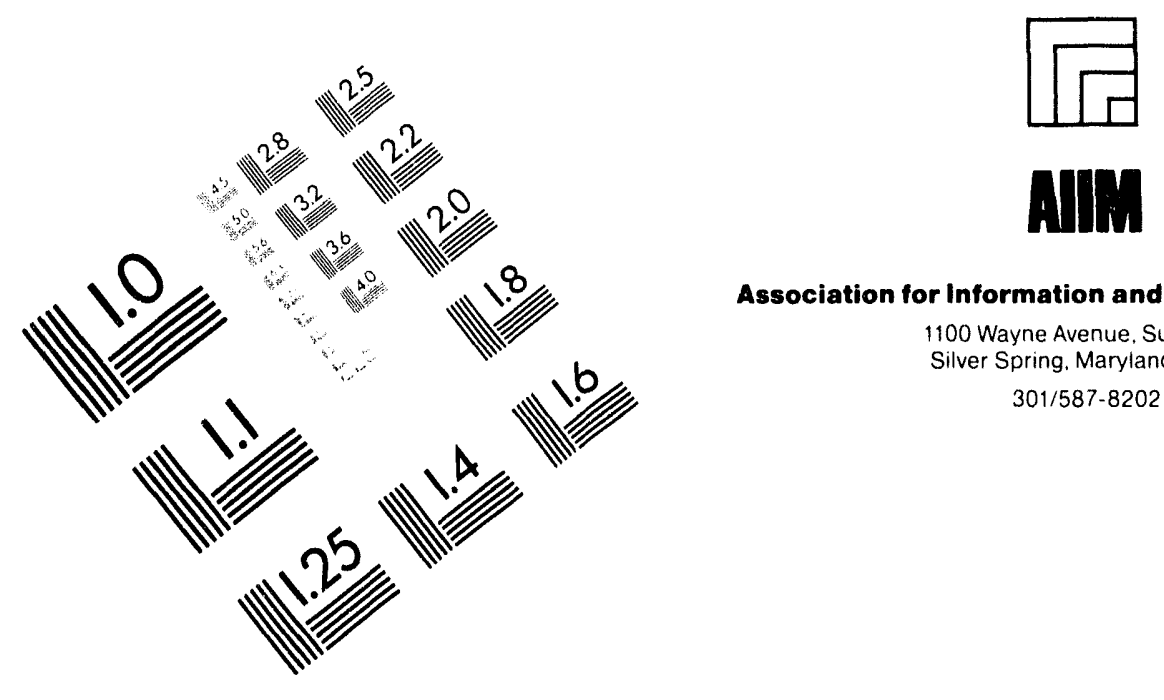

Association for Information and Image Management

1100 Wayne Avenue. Suite 1100

Silver Spring. Maryland 20910

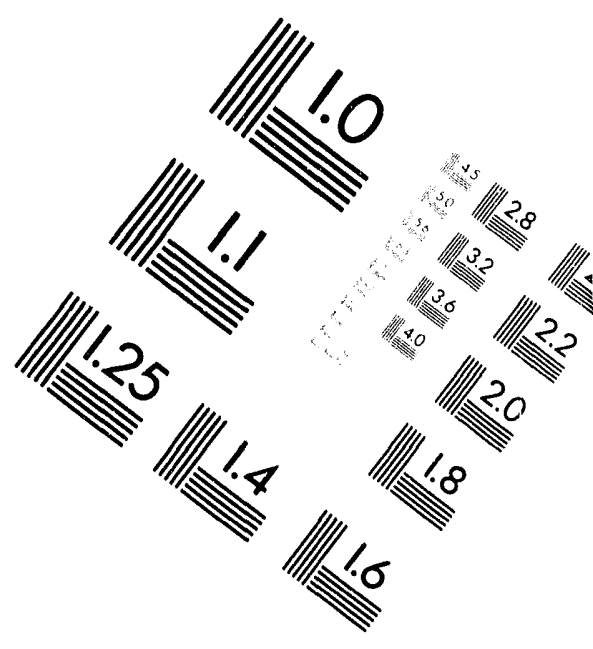

\section{Centimeter}

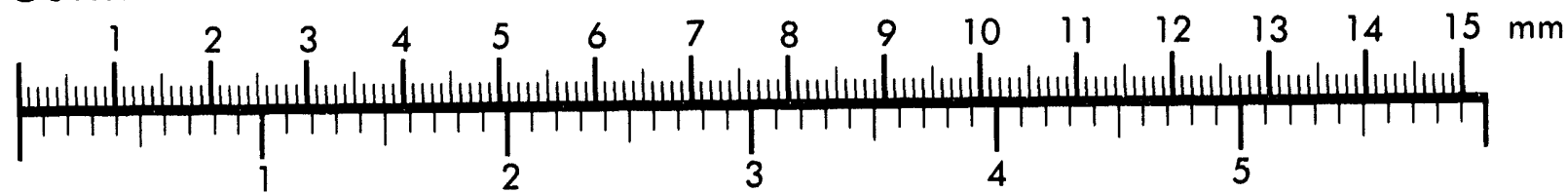
Inches
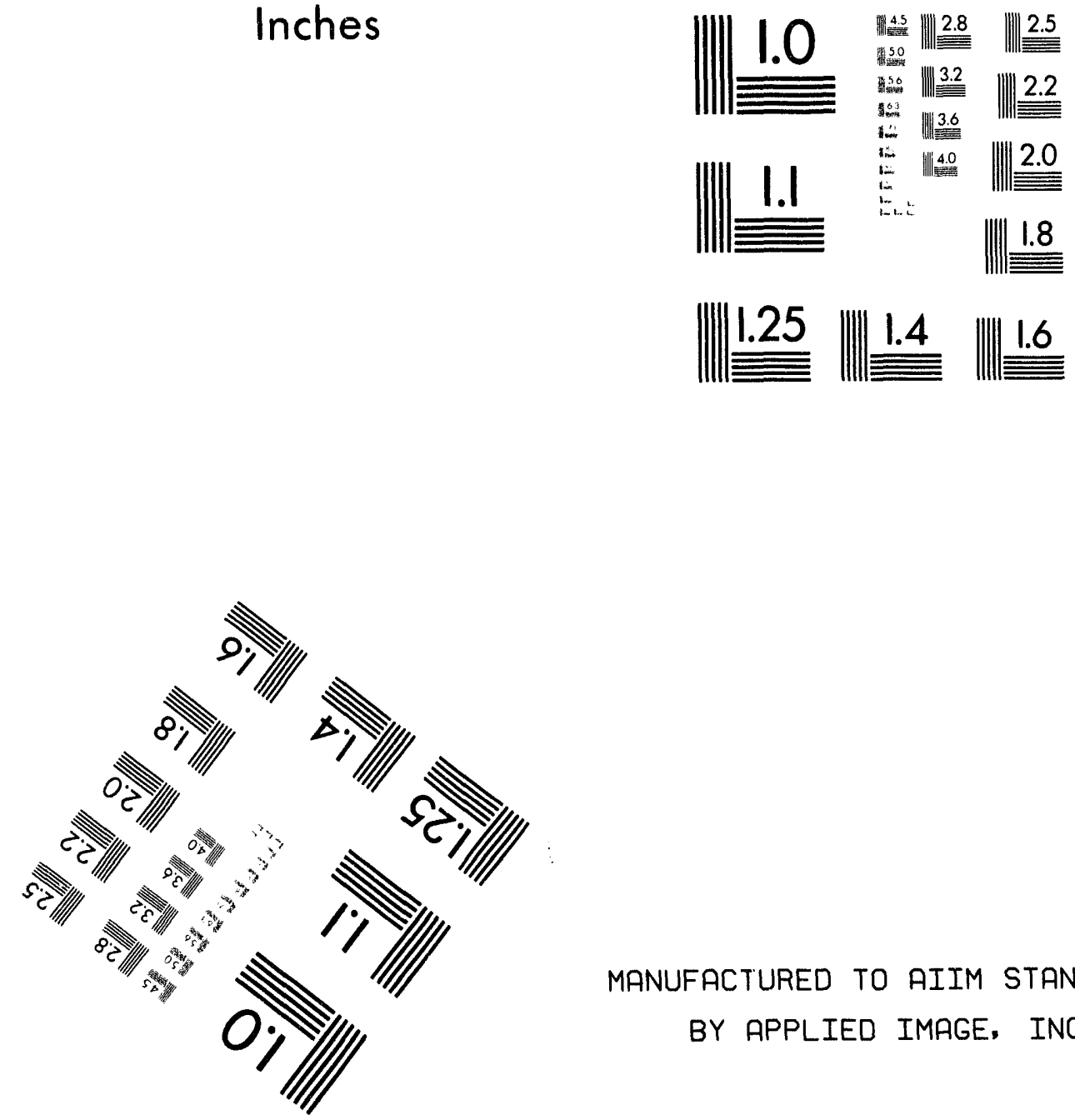

MANUFACTURED TO AIIM STANDARDS

BY APPLIED IMAGE, INC.

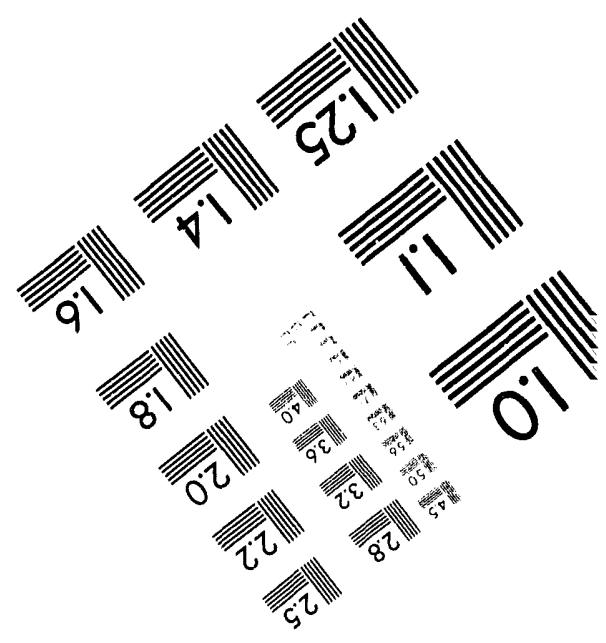



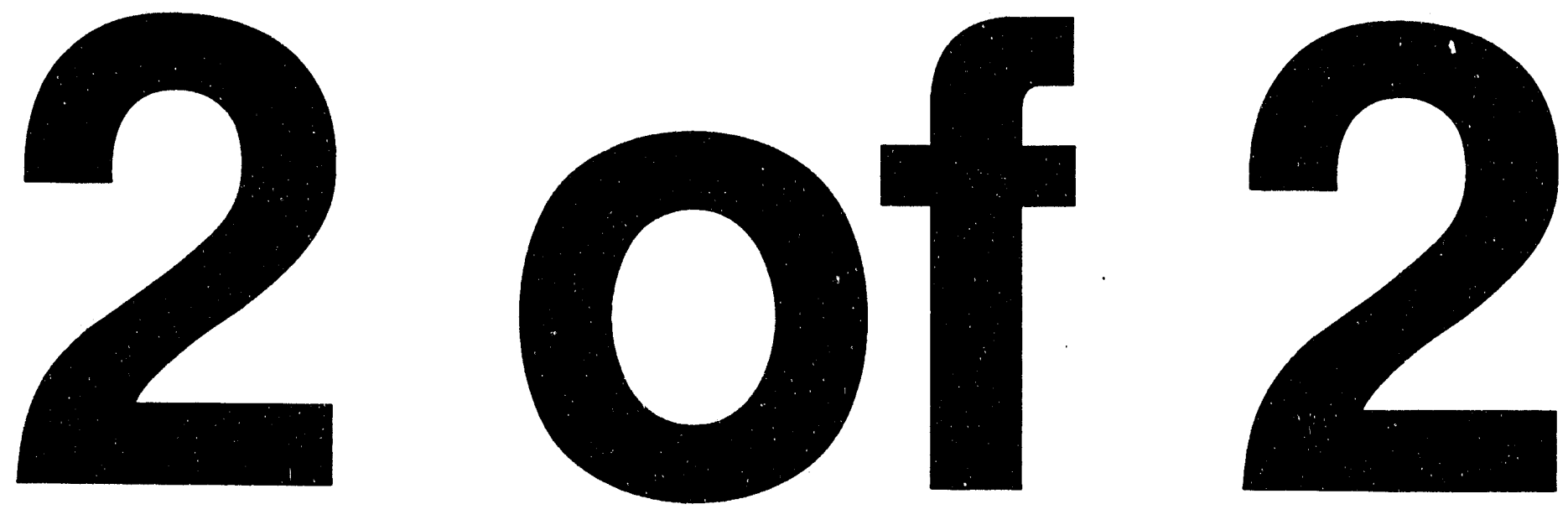
RASS Activities: Worksheet 3

\begin{tabular}{|c|c|c|}
\hline \multicolumn{2}{|c|}{ Attachment 30} & 1.13 \\
\hline & 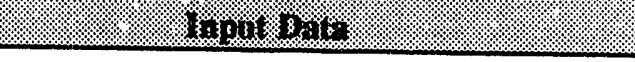 & 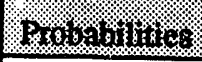 \\
\hline $37 a$ & Cultural impacts significance: & $\begin{array}{l}\text { A: } \\
\text { B: } \\
\text { C: } \\
\text { D: }\end{array}$ \\
\hline $37 \mathrm{~b}$ & Cultural impacts damage: & $\begin{array}{l}\text { A: } \\
\text { B: } 0.75 \\
\text { C: } 0.25 \\
\text { D: } \\
\end{array}$ \\
\hline $38 \mathbf{a}$ & Short-term land use quality and demand: & $\begin{array}{l}\text { A: } \\
\text { B: } \\
\text { C: } \\
\text { D: } \\
\text { E: }\end{array}$ \\
\hline $39 a$ & Long-term land use characteristics: & $\begin{array}{l}\text { A: } \\
\text { B: } \\
\text { C: } \\
\text { D: } \\
\text { E: } \\
\text { F: } \\
\end{array}$ \\
\hline $40 \mathrm{a}$ & Biotic sensitivity: & $\begin{array}{l}\text { A: } \\
\text { B: } \\
\text { C: } \\
\text { D: }\end{array}$ \\
\hline $40 \mathrm{~b}$ & Biotic damage: & $\begin{array}{l}\text { A: } \\
\text { B: } \\
\text { C: } \\
\text { D: } \\
\text { E: } \\
\text { F: } \\
\end{array}$ \\
\hline $41 \mathrm{a}$ & Natural resource sensitivity: & $\begin{array}{l}\text { A: } \\
\text { B: } \\
\text { C: } \\
\text { D: } \\
\text { E: }\end{array}$ \\
\hline $41 b$ & Natural resource damage: & $\begin{array}{l}\text { A: } \\
\text { B: } \\
\text { C: } \\
\text { D: } \\
\text { E: } \\
\text { F: }\end{array}$ \\
\hline
\end{tabular}


RASS Activities: Worksheet 3 (Cont.)

Attachment 31

Record ID:

1.13

Notes: line 37: Progress in "restoring" the land made over a 27-year period is reflected by assigning 0.75 probability to damage level $B$ and 0.25 probability to damage level $C$, which is a better score than that for the intermediate alternative. Regardless of how the site is left, it has local significance. 
1

2

3

4

5

6

7

8

9

10

11

12

13

14
Record ID:

ADS/TDD: $\quad$ ADS: 2220-1;TDD: $A A / A B$

Date: $\quad 08 / 24 / 92$

Preparer: $\quad$ H. Wagner

Phone: (509) $987-6543$

Field office: (check one)
$\square$ AL Albuquerque
$\square \mathrm{CH}$ Chicago
$\square$ FS Fernald
$\square \mathrm{HQ}$ Headquarters
$\square$ ID Idaho
$\square$ NV Nevada
$\square$ OR Oak Ridge
$\square$ RF Rocky Flats

D RL Richland

$\square$ SF San Francisco

$\square$ SR Savannah River

7 Installation name: Hanford

Funding unit name: Waste Processing Module 1

Activity name: Waste Processing Module 1-Mixed Waste

0 Alternative name: Operations

1

$\begin{aligned} \text { Waste type: } & \square \text { TRU } \\ \text { (check one) } & \square \text { HLW } \\ & \square \text { LLW } \\ & \square \text { Hazardous }\end{aligned}$

$\Delta$ Mixed

$\square$ Sanitary

$\square$ Industrial wastewater

$\square$ Other:

2 Activity type: $\square$ Treatment (check one) $\square$ Disposal
$\square$ Storage
$\square$ Transportation
$\square$ Other:

13 Facility starus:

(check one) $\square$ Existing

Notes: line 1: record ID 1.23 denotes funding unit 1, activity 2, alternative 3 
Attachment 33

RASS Activities: Form 2

Record ID:

1.23

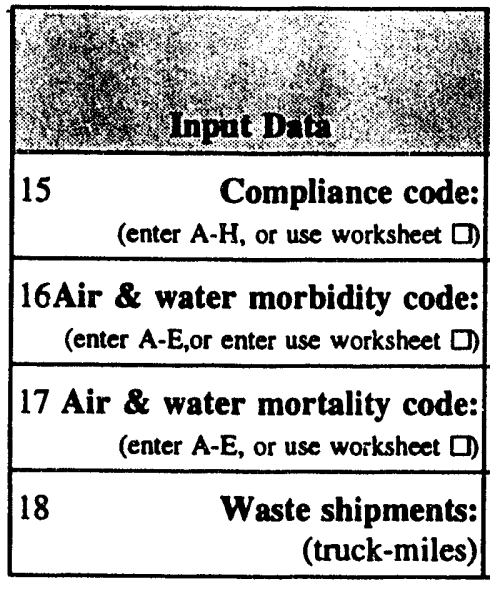

\begin{tabular}{|c|c|c|}
\hline $\begin{array}{l}\text { Budget } \\
\text { age }\end{array}$ & 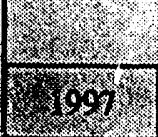 & 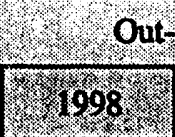 \\
\hline & & \\
\hline & & \\
\hline & & \\
\hline & & \\
\hline & & \\
\hline & & \\
\hline & & \\
\hline
\end{tabular}

19 Risk to future generations:

a.

b.

c.
Waste type code:

Amount of waste:

Potential code:
(A-E)

Unit of measure:

(enter A-D, or use worksheet [D)

\begin{tabular}{|lr|}
\hline 20 & Radiation exposure (per-h): \\
\hline 21 & Chemical exposure (per-h): \\
\hline 22 & Construction (per-h): \\
\hline 23 & Operations (per-h): \\
\hline 24 & S\&H programs (\$): \\
\hline
\end{tabular}

Units for line 26: $\square \mathrm{m}^{3}$

(check one) $\square$ gallons
$\square \mathrm{ft}^{3}$
$\square$ lbs
$\square$ thousand gallons
$\square$ thousand $\mathrm{ft}^{3}$
$\square$ tons

\begin{tabular}{l|l|l|} 
& & \\
\hline & & \\
\hline & & \\
\hline
\end{tabular}

\begin{tabular}{|l|l|l|l|}
\hline & & \\
\hline & & \\
\hline & & \\
\hline & & \\
\hline & & \\
\hline
\end{tabular}

$\square$ thousand $\mathrm{m}^{3}$

$\square$ million $\mathrm{m}^{3}$

$\square$ barrels

$\square$ million $\mathrm{ft}^{3}$

$\square$ other

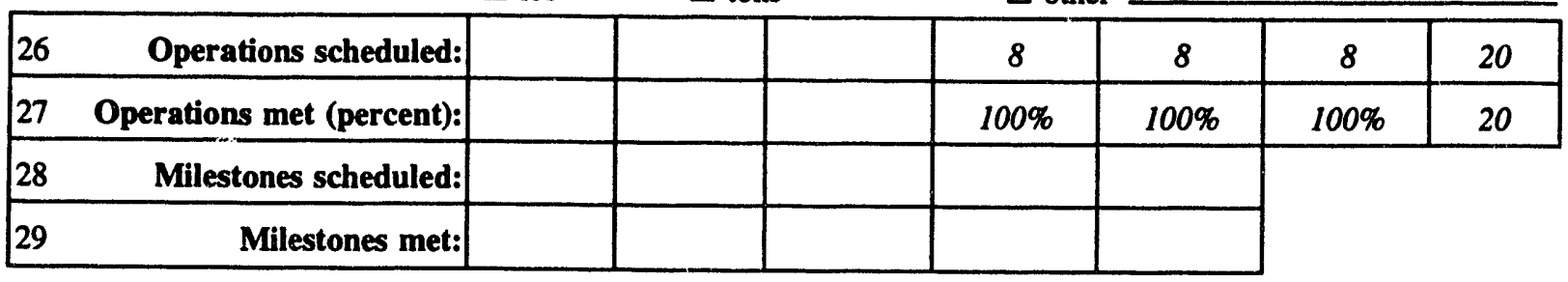

30 New capacity status:

a. Schedule status code:

b. Completion date:

(enter A-J, or use worksheet $\square$ )

11

\begin{tabular}{|r|l|l|l|l|l|l|l|}
\hline $31 \quad$ Funding request (\$M): & & & & & & & \\
\hline $32 \quad$ Fines (\$M): & & & & & & & \\
\hline $33 \quad$ Cost penalties (\$M): & & & & & & & \\
\hline $34 \quad$ Cost savings (\$M): & & & & & & & \\
\hline $35 \quad$ Waste minimization (\$M): & & & & & & & \\
\hline $36 \quad \begin{array}{r}\text { Public concern code: } \\
\text { (enter A-E, or use worksheet } \square\end{array}$ & & & & & & & \\
\hline
\end{tabular}


1

2

3

4

5

6

7 Installation name:

8 Funding unit name:

9

10

11

12

13

14
Record ID: $\quad-1.33$

ADS/TDD: $\quad A D S: 2220-1 ; T D D:$ AAVAB

Date: $\quad 08 / 24 / 92$

Preparer: $\quad H$. Wagner

Phone: (509) $987-6543$

Field office: $\square$ AL Albuquerque (check one)

$\square \mathrm{CH}$ Chicago

$\square$ FS Fernald

$\square \mathrm{HQ}$ Headquarters
G RL Richland

$\square$ SF San Francisco

$\square$ SR Savannah River $\square$ NV Nevada

$\square$ OR Oak Ridge

$\square$ RF Rocky Flats

Hanford

Waste Processing Module 1

Activity name: Waste Processing Module 1-Low-Level Waste

Alternative name: Operations

$\begin{array}{lll}\text { Waste type: } & \square \text { TRU } & \square \text { Mixed } \\ \text { (check one) } & \square \text { HLW } & \square \text { Sanitary } \\ & \square \text { LLW } & \square \text { Industrial wastewater } \\ & \square \text { Hazardous } & \square \text { Other: }\end{array}$

Activity type: Treatment

$\square$ Storage

(check one) $\square$ Disposal

$\square$ Transportation

$\square$ Other:

\section{Facility status: $\square$ Proposed}

(check one) $\square$ Existing

Notes: $\quad$ line 1: record $I D 1.33$ denotes funding unit 1 , activity 3 , alternative 3 
Attachment 35

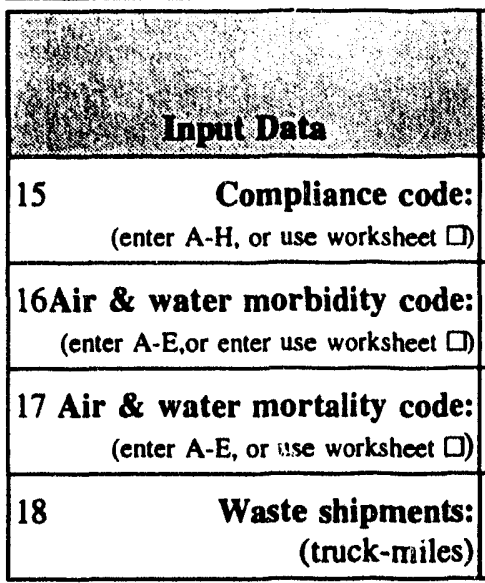

19 Risk to future generations:

\begin{tabular}{|lr|}
\hline 20 & Radiation exposure (per-h): \\
\hline 21 & Chemical exposure (per-h): \\
\hline 22 & Construction $($ per- $-\mathrm{h}):$ \\
\hline 23 & Operations $($ per- $-\mathrm{h}):$ \\
\hline 24 & S\&H programs $(\$):$ \\
\hline
\end{tabular}

RASS Activities: Form 2

Record ID: 1.33

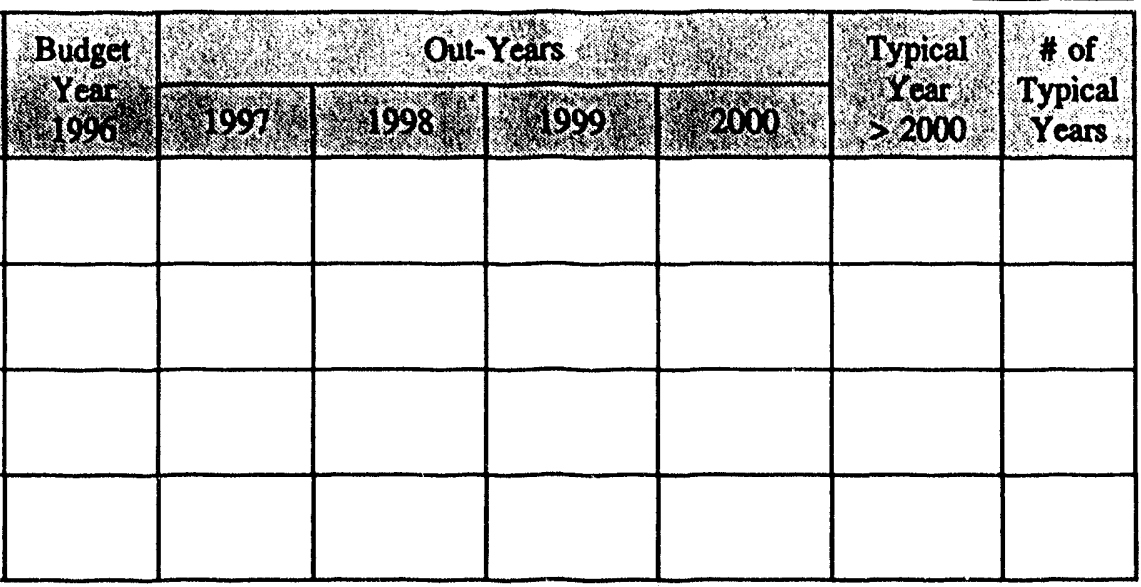

a.

b.

c.
Waste type code:

Amount of waste:

Potential code:
(A-E)

Unit of measure:

(enter A-D, or use worksheet $\square$ )

\begin{tabular}{|l|l|l|l|l|l|l|}
\hline & & & & & & \\
\hline & & & & & & \\
\hline & & & & & & \\
\hline
\end{tabular}

25 Units for line 26: $\square \mathrm{m}^{3}$ (check one) $\square$ gallons

$\square \mathrm{ft}^{3}$
$\square \mathrm{lbs}$

$\square$ thousand $\mathrm{m}^{3}$

$\square$ thousand gallons

D] thousand $\mathrm{ft}^{3}$

$\square$ tons $\square$ million $\mathrm{m}^{3}$

$\square$ barrels

$\square$ million $\mathrm{ft}^{3}$

$\square$ other

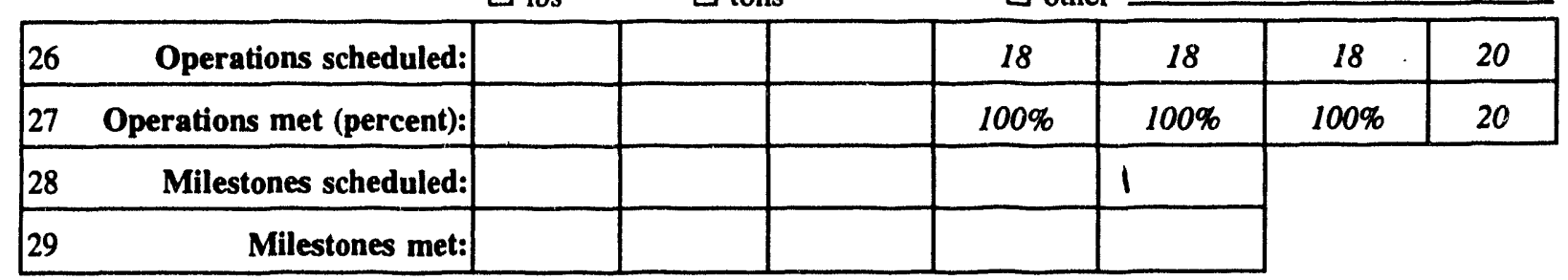

30 New capacity status:

a. Schedule status code:

b. Completion date:

(enter A-J, or use worksheet $\square$ )

b.

\begin{tabular}{|r|l|l|l|l|l|l|l|}
\hline $31 \quad$ Funding request $(\mathbf{\$ M}):$ & & & & & & & \\
\hline $32 \quad$ Fines (\$M): & & & & & & & \\
\hline $33 \quad$ Cost penalties $(\mathbf{\$ M}):$ & & & & & & & \\
\hline $34 \quad$ Cost savings (\$M): & & & & & & & \\
\hline $35 \quad$ Waste minimization (\$M): & & & & & & & \\
\hline $36 \quad \begin{array}{r}\text { Public concern code: } \\
\text { (enter A-E, or use workshoet } \square\end{array}$ & & & & & & & \\
\hline
\end{tabular}


APPENDIX D:

RESOURCE ALLOCATION SUPPORT SYSTEM DATA FORMS 2 AND 3: BACKGROUND INFORMATION 


\section{APPENDIX D:}

\section{RESOURCE ALLOCATION SUPPORT SYSTEM DATA FORMS 2 AND 3: BACKGROUND INFORMATION}

This appendix provides background information that may be helpful to persons required to prepare data forms 2 and 3, which provide input data for the Resource Allocation Support System (RASS). The sections are arranged according to the order in which the input data are recorded in forms 2 and 3 (Appendix C). Background information for form 1 is not provided because form 1 is relatively straightforward to complete.

\section{D.1 COMPLIANCE CODE (Line 15)}

The compliance code is a constructed scale used to rate levels of compliance for waste management (WM) activities. These levels range from full compliance with all federal, state, or local laws and Native American treaties to conditions that shut down certain operations. Each of the eight levels on the compliance scale indicates a different situation and consequence of noncompliance (Table D.1).

\section{TABLE D.1 Constructed Scale for Compliancea}

\begin{tabular}{|c|c|}
\hline $\begin{array}{l}\text { Scale } \\
\text { Level }\end{array}$ & Description \\
\hline $\mathbf{A}$ & Full compliance \\
\hline B & $\begin{array}{l}\text { Nonconformity with a DOE reference standard or other established "good } \\
\text { practice" guidance }\end{array}$ \\
\hline $\mathbf{C}$ & Delay in meeting a Tiger Team milestone \\
\hline $\mathbf{D}$ & $\begin{array}{l}\text { Violation of a standard that is mandatory under DOE policy or violation } \\
\text { of a provision of a DOE order involving a standard that is mandatory } \\
\text { under a DOE policy }\end{array}$ \\
\hline $\mathbf{E}$ & $\begin{array}{l}\text { Request for an accommodation in complying with a statutory requirement } \\
\text { that leads to a negotiated agreement for a compliance schedule }\end{array}$ \\
\hline $\mathbf{F}$ & Dispute in a Tri-Party Agreement that leads to work stoppage \\
\hline G & $\begin{array}{l}\text { Dispute in a Tri-Party Agreement or Native American treaty that leads } \\
\text { to litigation }\end{array}$ \\
\hline $\mathbf{H}$ & $\begin{array}{l}\text { Request for an accommodation in complying with a statutory requirement } \\
\text { that is refused and leads to a shutdown of certain operations }\end{array}$ \\
\hline
\end{tabular}

a Letters denote level of severity from low (A) to high (H); use with line 15 of form 2. 
Proposals for future WM work that would result in serious compliance issues are not expected or encouraged; most proposed work is expected to result in full compliance (i.e., a level A rating). Nevertheless, under severe budget constraints, it may not be possible to achieve full compliance for one or more alternatives for some funding units.

The level of compliance is estimated for each year of every activity. In general, the level of compliance is expected to improve as funding increases. When more than one compliance issue is involved, the level of each issue is noted on a separate data form for each issue. If the compliance level is uncertain, probabilities are used to estimate likely outcomes (e.g., a 75\% chance of level A and a 25\% chance of level E). Probabilities are entered on line 15 of worksheet 2. (Examples of worksheets are given in Appendix C.) Sections D.1.1D.1.8 discuss the levels used in the constructed scale for compliance.

\section{D.1.1 Level A: Full Compliance}

Level A indicates that the funding unit fully complies with good practice standards, the U.S. Department of Energy's (DOE's) mandatory policy standards, and statutory requirements. Deviations from full compliance are categorized by levels B through $\mathrm{H}$.

\section{D.1.2 Level B: Nonconformity with a DOE Reference Standard or Other Established "Good Practice" Guidance}

DOE Order 5480.4, Environmental Protection, Safety, and Health Protection Standards, defines reference standards that DOE and its contractors should apply in addition to mandatory standards. Attachment 3 to DOE 5480.4 lists reference standards that apply to emergency preparedness, environmental protection, fire protection, health protection, occupational safety, nuclear safety, and transportation safety. These reference standards include handbooks (e.g., the Handbook of Fire Protection); technical standards developed by professional societies such as the Institute of Electrical and Electronics Engineers and the American Nuclear Society; manuals (e.g., the National Safety Council's Accident Prevention Manual for Industrial Operations); and certain U.S. Nuclear Regulatory Commission (NRC) regulations that are mandatory for NRC licensees (e.g., 10 Code of Federal Regulations Part 20, "NRC Standards for Protection against Radiation"). DOE Order 5480.4 may not contain a comprehensive list of reference standards; therefore, a level B rating also applies when a funding unit does not conform with an established good practice standard listed as a reference standard in DOE 5480.4. Because reference standards and good practice standards are not mandatory, nonconformity with them is considered the least serious deviation from full compliance.

\section{D.1.3 Level C: Delay in Meeting a Tiger Team Milestone}

In 1990, teams of experts assessed how well DOE facilities met environmental, safety, and health (ES\&H) responsibilities. These teams, known as Tiger Teams, issued 
reports that identified problems requiring corrective actions. In response to the Tiger Team findings, DOE and its contractors developed action plans to correct these problems. Such plans give an excellent snapshot of a funding unit's ES\&H problems at the time of the assessment and aid in the review of possible deviations from full compliance for use in the RASS process.

The action plans contain a schedule of milestones for each finding. Usually, one of several milestones associated with a finding identifies when the problem is expected to be corrected. A level $\mathrm{C}$ compliance deviation applies when the milestone for correction of a problem has not been met. Usually, the problem involves nonconformity with a good practice standard or violates a mandatory standard. Therefore, a delay in meeting a Tiger Team corrective action milestone aggravates the underlying deviation from full compliance, and a level $\mathrm{C}$ deviation usually accompanies a level B, D, or $\mathrm{E}$ compliance deviation for the funding unit in question.

\section{D.1.4 Level D: Violation of a Standard that Is Mandatory under DOE Policy or a Provision of a DOE Order that Involves a Standard that Is Mandatory under a DOE Policy}

DOE Order 5480.4, Environmental Protection, Safety, and Health Protection Standards, identifies two kinds of mandatory ES\&H standards: (1) statutory requirements mandatory under non-DOE federal or state ES\&H statutes and/or implementing requirements and (2) policy requirements mandatory under NOE policy. Attachment 1 of DOE 5480.4 contains an incomplete list of statutory requirements. Attachment 2 lists mandatory policy standards from other sources. Mandatory provisions in DOE orders (provisions using the commands "shall" or "shall not") may be either statutory requirements or mandatory policy standards. Violation of a mandatory policy standard can be corrected internally between DOE and its contractor. Correcting statutory violations involves outside agencies, possibly courts, and a greater risk of adverse public opinion. Therefore, RASS considers a funding unit activity that violates a mandatory policy standard to be more harmful than a policy that violates a nonmandatory DOE policy and less harmful than one that violates a statutory requirement.

\section{D.1.5 Level E: Request for an Accommodation in Complying with a Statutory Requirement that Leads to a Negotiated Agreement for a Compliance Schedule}

The DOE policy requires compliance with all statutory requirements; however, at times, it is apparent that a statutory requirement will not be met. In this case, a DOE employee who knows the situation should promptly notify DOE so that DOE can inform the cognizant agency that the requirement will not be met unless an accommodation is made. This notification can result in two possible outcomes: a negotiated agreement or "no agreement." It is assumed that DOE employees and its contractors will conform to DOE policy and to the strictures of the Federal Facilities Compliance Act of 1992 to preclude no 
agreement outcomes. Thus, the compliance scale does not have levels associated with civil fines or criminal sanctions. A negotiated agreement results in a schedule for compliance with the statutory requirement. Assigning a level $\mathrm{E}$ rating is appropriate when a negotiated agreement requires a funding activity to comply with a statutory requirement. The level $\mathrm{E}$ rating is assigned, starting in the year when knowledge of the violation was acquired or is expected. The scorer determines whether the level $E$ rating ends either when the negotiated agreement is reached or when the underlying problem is expected to be corrected for a. particular funding activity.

\section{D.1.6 Level F: Dispute in a Tri-Party Agreement that Leads to Work Stoppage}

Parties to a Tri-Party Agreement are generally DOE, another federal agency (usually the U.S. Environmental Protection Agency, and a state agency that may be authorized by the federal agency to administer a state program in lieu of the federal program. Tri-party agreements may be reached in the context of litigation and may also be consent orders. They typically call for work to correct the underlying problem(s) that violate the statutory requirements. On the basis of the Hanford Federal Facility Agreement and Consent Order, ${ }^{1}$ two events in Tri-Party Agreement disputes indicate deviations from DOE's policy. Assigning a level $\mathrm{F}$ rating is appropriate if the cognizant federal or state agency orders, or is expected to order, work stopped on a funding unit activity because actions taken to correct an underlying compliance problem are inadequate or defective.

\section{D.1.7 Level G: Dispute in a Tri-Party Agreement or Native American Treaty that Leads to Litigation}

A highly visible and serious deviation from full compliance may involve litigation. For example, litigation can result if resolution cannot be reached in a dispute involving a Tri-Party Agreement or Native American treaty. In such cases, a level G rating is applied to those funding unit activities, starting with the year in which court papers for litigation were filed or are expected to be filed. The scorer determines whether to remove the level G rating in the year in which either the judicial decision is made or the underlying problem is corrected.

1 Washington State Department of Ecology, U.S. Environmental Protection Agency, and U.S. Department of Energy, 1990, Hanford Federal Facility Agreement and Consent Order, 89-10, Rev. 1, First Amendment, August. 


\section{D.1.8 Level H: Request for an Accommodation in Complying with a Statutory Requirement that Is Refused and Leads to a Shutdown of Certain Operations}

A request for an accommodation may be denied, in which case DOE must shut down the facilities or operations that caused the problem. For example, if several operations produce hazardous waste and the host installation does not have waste storage facilities in accordance with Resource Conservation Recovery Act requirements, all operations that produce hazardous wastes would have to be shut down. A level $\mathrm{H}$ rating designates the worst deviation from full compliance because it most likely occurs as a result of an egregious violation of a statutory requirement that, in the view of the cognizant agency, may also involve "bad faith" on the part of DOE. A level $\mathrm{H}$ rating begins in the year when the statutory violation became or is expected to become known. Shutdown of certain operations could result in significant WM systems costs. Therefore, the scorer should seriously consider the estimated length of the shutdown. If the operations that would be shut down are important to DOE, more immediate action (i.e., weeks or months rather than years) is likely required to satisfy the cognizant agency. The agency and DOE would then negotiate an agreement to convert the level $H$ rating to a level $E$ rating and to end the associated WM systems cost.

\section{D.2 SAFETY AND HEALTH (Lines 16-24)}

As illustrated in Figure D.1, the safety and health (S\&H) objective considers impacts to both the public and workers (support and administrative staff are not included). Both require data to estimate morbidity (e.g., sickness or injury) and mortality. Lines 16-24 of form 2 address factors that affect public and worker safety and health.

\section{D.2.1 Risks to the Public (Lines 16-19)}

Most WM activities probably do not involve public impacts. However, RASS must be able to evaluate the safety and health of persons who might be affected by WM activities. Risks to public safety and health result from (1) exposures to chemicals or radiation through air, groundwater, or surface-water exposure pathways; (2) accidents (associated with transport of wastes); or (3) risks to future generations. RASS measures for these factors are discussed below.

\section{D.2.2 Air and Water Morbidity Code (Line 16)}

Because air, groundwater, and surface-water exposure pathways are complicated, it is necessar. to use constructed scales that consider order-of-magnitude estimates of the number of people affected (e.g., $0,0-1,1-10,10-100,>100$ ) and the severity of the effect (e.g., morbidity or mortality). Line 16 addresses morbidity (time lost because of sickness or injury). 


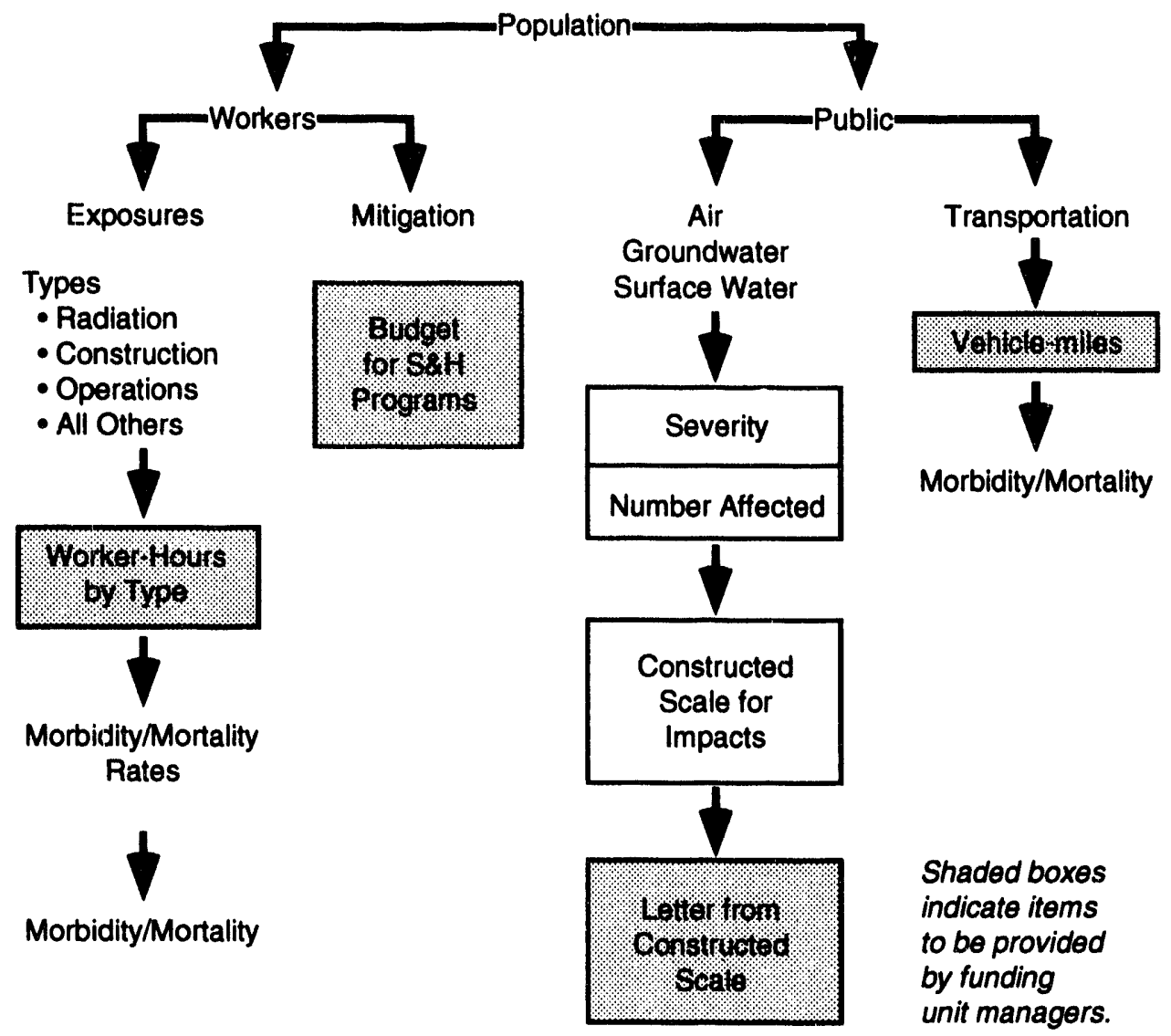

FIGURE D.1 Safety and Health Considerations

The constructed scale for the RASS air and water morbidity code is shown in Table D.2. Level A ("no people affected in any way") is expected to be assigned in most cases. Levels B through E denote increasing levels of severity. This scale is deliberately "coarse" because detailed studies on which to base more precise estimates are not generally available, and the intent is to identify potentially serious sets of conditions. However, more precise estimates (if available) can also be recorded on the form. For example, if the number of people injured or sick is expected to be 20 , let

$$
P(A)=1-\frac{20}{55}=0.64
$$

and

$$
P(D)=\frac{20}{55}=0.36,
$$

where $P(A)$ and $P(D)$ denotes the probability of levels $A$ and $D$, respectively. 
The factor of 55 enters these equations because the midpoint (which is treated as the expected value in the statistical sense) of level $D$ is 55 people. Thus, the midpoint (55 people) multiplied by a probability of 0.36 results in the number of people expected to become injured or sick (i.e., 20 persons). RASS used a factor to convert sickness and injury to person-days-lost.

\section{D.2.3 Air and Water Mortality Code} (Line 17)

The constructed scale for the RASS air and water mortality code is shown in Table D.3. Level A ("no people affected in any way") is expected to be assigned in most cases. Levels $B$ through $\mathbf{E}$ denote increasing levels of severity. This scale is deliberately "coarse" because detailed studies on which to base more precise estimates are not generally available, and the intent is to identify potentially serious sets of conditions. However, precise estimates (if available), can also be recorded on the form. For example, if the expected mortality is $10^{-6}$, let

$$
P(A)=1.2 \times 10^{-6}
$$

and

$$
P(B)=2 \times 10^{-6} .
$$

The factor of 2 enters these equations because the midpoint (which is treated as the expected value in the statistical sense) of level $B$ is 0.5 fatalities. Thus, the midpoint ( 0.5 fatalities) multiplied by a probability of $2 \times 10^{-6}$ results in $10^{-6}$ expected fatalities.

\section{D.2.4 Waste Shipments (Line 18)}

To determine impacts from transporting wastes, it is necessary to estimate the number of truck-miles required for shipping waste. These estimates are combined with standard factors for routine highway accidents (that do not involve radiation releases) to estimate morbidity and mortality for public populations. 


\section{D.2.5 Risk to Future Generations (Line 19)}

RASS considers three components of risk to future generations: (1) the type of waste left at the site, (2) the amount of land, and (3) the potential for releases to the accessible environment over 10,000 years. Components 1 and 3 are described by constructed scales. Component 2 is specified directly.

Tables D.4 and D.5 list scales for waste types and the potential for releases, respectively. The five-point scale on waste type ranges from wastes that are neither hazardous nor radioactive to high-level or transuranic wastes. The four-point relf;ase potential scale ranges from no potential for releases to some potential for releases.

\section{D.2.6 Risks to Workers (Lines 20-24)}

As WM activities proceed, workers may be exposed to radiation or chemicals or to accidents from construction or routine operations. The work environments for some workers may involve more than one of these types of exposures. Therefore, it is necessary to estimate (for each activity), the number of person-hours that involve exposure to radiation, chemicals, construction activities, and routine operations. Standard conversion factors are used to estimate morbidity and mortality for each type of activity. More specific conversion factors (if available) at a site are used instead of the standard factors.

\section{D.2.7 Radiation Exposure (Line 20)}

Radiation exposure is included in the data primarily because radiological exposure can lead to premature death to workers. A likely pattern is that exposure to radiation causes cancer that leads to death. The number of person-hours of exposure to radiation specified on
TABLE D.3 Air and Water Mortality Code: Constructed Scale for Public Safety and Health Mortality Effects Due to Air and Water Exposure Pathways

\begin{tabular}{cc}
\hline $\begin{array}{c}\text { Scale } \\
\text { Level }\end{array}$ & $\begin{array}{c}\text { Expected Number of } \\
\text { Fatalities }\end{array}$ \\
\hline A & 0 \\
B & $>0$ to 1 \\
C & $>1$ to 10 \\
D & $>10$ to 100 \\
E & $>100$ \\
\hline
\end{tabular}

a Letters denote level of severity from low (A) to high (E); use with line 17 of form 2.

TABLE D.4 Risk to Future Generations: Type of Waste Left On-site

\section{Scale \\ Level Description}

A Wastes are neither hazardous norradioactive

B Hazardous metals

C Low-level radioactive wastes

D Mixed wastes

E High-level or transuranic wastes

a Letters denote level of severity from low (A) to high (E); use with line 19a of form 2 . 
line 20 for each of the funding unit alternatives to be analyzed by RASS. RASS uses a linear dose-response model to calculate the cumulative effects of radiological exposure. It is rare, and unexpected, that radiological exposure would be high enough to cause an immediate fatality. However, accidents of this magnitude do occur, and the conversion factor used in RASS accounts for such occurrences.

\section{D.2.8 Chemical Exposure (Line 21)}

As with radiological exposure, the primary concern with chemical exposure is that it can lead to premature death. The number of person-hours of exposure to chemicals is specified on line 21 for each of the funding unit alternatives to be analyzed. RASS uses a linear dose-response model to calculate the cumulative effects of chemical exposure. Although chemical exposure rarely is high enough to cause an immediate fatality, the conversion factor used in RASS accounts for such occurrences.

\section{D.2.9 Construction (Line 22)}

TABLE D.5 Risk to Future Generations: Potential for Releases to the Accessible Environment over 10,000 Years

\begin{tabular}{cl}
$\begin{array}{c}\text { Scale } \\
\text { Level }\end{array}$ & \multicolumn{1}{c}{ Description } \\
\hline A & No potential for releases \\
B & $\begin{array}{l}\text { Very low potential for } \\
\text { releases (comparable to } \\
\text { repository storage with } \\
\text { favorable environmental } \\
\text { conditions) }\end{array}$ \\
C & $\begin{array}{l}\text { Low potential for releases } \\
\text { (comparable to monitored } \\
\text { retrievable storage with } \\
\text { favorable environmental } \\
\text { conditions) }\end{array}$ \\
D & $\begin{array}{l}\text { Some potential for releases } \\
\text { (comparable to underground } \\
\text { vault storage with } \\
\text { unfavorable environmental } \\
\text { conditions) }\end{array}$ \\
\hline
\end{tabular}

a Letters denote level of severity from low (A) to high (D); use with line 19c of form 2.

Accidents occur during construction of buildings, machinery, electrical service, sewer and water lines, roads, and other facilities. The number of person-hours of construction activity is specified on line 22 for each of the funding unit alternatives to be analyzed by RASS. RASS uses average conversion factors based on occupational statistics compiled by the National Safety Council to relate the number of person-hours worked to the number of hours of lost work time during construction activities (Accident Facts, 1991 Ed., National Safety Council, Chicago, Ill.).

\section{D.2.10 Operations (Line 23)}

Accidents that lead to lost work time and sometimes death occur during routine operations at all DOE facilities. The risk of workers to accidents and mortality as a result of routine operations is a natural scale. The number of person-hours of routine operations is specified on line 23 for each of the funding unit alternatives to be analyzed by RASS. RASS uses average conversion factors based on occupational statistics to relate the number of person-hours to an estimate of the number of hours of lost work time and fatalities. 


\section{D.2.11 Safety and Health Programs (Line 24)}

Earmarking funds for mitigation measures (e.g., worker training and S\&H programs) has some benefit beyond that of meeting requirements for compliance. For RASS to account for these brenefits, it is necessary to specify the budget earmarked for such programs. A direct credit to equivalent cost is given for this spending.

\section{D.3 WASTE MANAGED (Lines 25-30)}

The term "waste managed" includes activities necessary for treatment, storage, and disposal (TSD) of wastes. Some of these activities are support activities and do not directly involve actual TSD activities. Figure D.2 indicates three categories of waste managed activities:

- Providing for new TSD capacity;

- Conducting TSD operations; and

- Meeting milestones.

\section{D.3.1 Units for Line 26 (Line 25)}

The units of measure for TSD are specified on line 25 for operations scheduled and specified on line 26. The choices allow specification of solid and liquid wastes by weight or volume.

\section{D.3.2 Operations Scheduled (Line 26)}

The amount of waste to be treated, stored, or disposed of in a particular year is specified on line 26. This amount is to be the largest amount that can be processed among all alternatives for a particular funding unit (usually the long-range alternative). The actual amount to be processed depends on the percentage of scheduled operations that will be met, which is specified on line 27.

\section{D.3.3 Operations Met (Line 27)}

As levels of funding decrease, the proposed alternatives may not achieve the TSD operations scheduled. Therefore, the actual percentage of scheduled operations estimated to be met in each year (the amount processed at this funding level in a specific year) is specified on line 27. 


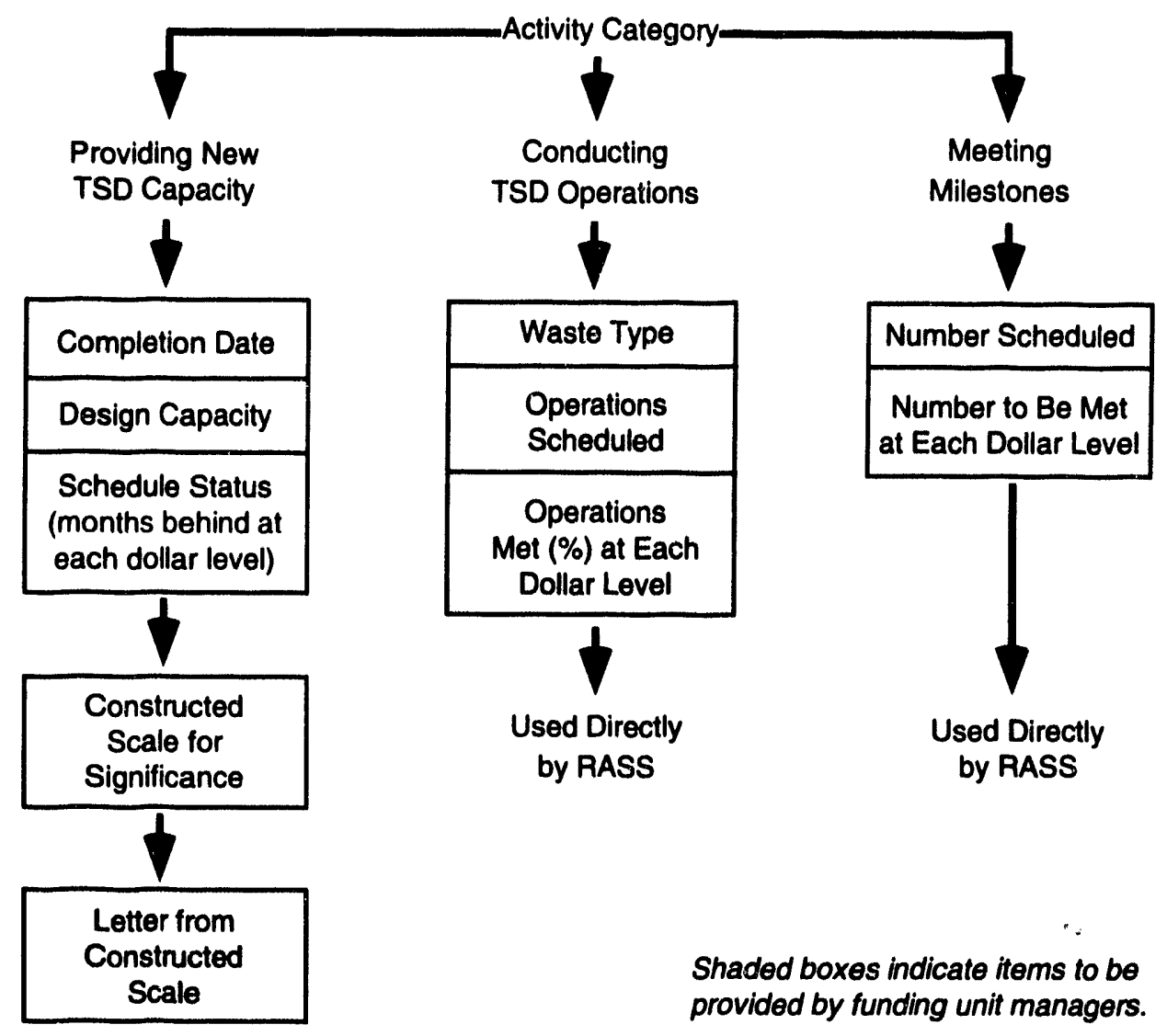

\section{FIGURE D.2 Three Categories of Waste Managed Activities}

\section{D.3.4 Milestones Scheduled (Line 28)}

A large number of milestones may be associated with a funding unit; however, RASS only considers milestones tracked by DOE Headquarters. The measure of effectiveness used by RASS is a weighted average (earlier years are given more weight than later years) of the percent of milestones met over a five-year period beginning with the budget year. Thus, two aspects of milestones are specified: the number of milestones scheduled and the number of milestones met (or expected to be met).

These milestones are detailed in the installation summaries (e.g., "complete conversion of nine vaults to mixed storage"). The number of Headquarters-tracked milestones scheduled each year for each activity is specified on line 28 . In most cases, the milestones scheduled each year are milestones achievable in the long-range funding unit alternative. 


\section{D.3.5 Milestones Met (Line 29)}

As levels of funding decrease, milestones may be delayed or missed altogether for the proposed alternatives. The number of milestones met (either on time or late) during each year is specified on line 29.

\section{D.3.6 New Capacity Status (Line 30)}

Progress on constructing new facilities or increasing the capacity of existing facilities is recorded on line 30 . The significance of the schedule status (line 30a) is affected by the scheduled completion date (line 30b). For example, an estimated slippage of six months may not be critical for a seven-year project, but it would be significant for a one-year project. Table D.6 presents a constructed scale that captures this impact. This scale consists of levels A through J, where level A is the most desirable level. Table D.6 addresses both the year of scheduled completion and the number of months' delay. The appropriate scale letter is entered on line 30a. The actual date entered in line 30b clarifies the entry on line 30a.

If a funding unit alternative is made up of two or more activities, the activities need to be considered together in order to specify the likely delay for the funding unit alternative. In these situations, one activity takes sole responsibility for all delays.

\section{D.4 WM SYSTEMS COST (Lines 31-34)}

Waste management systems cost is composed of WM funding requests, fines, cost penalties, and system cost savings. Funding unit managers specify these components, and RASS uses them to calculate the overall WM systems cost figure.

\section{D.4.1 Funding Request (Line 31)}

A WM funding request is the requested or anticipated WM funding for an activity for a specific year (budget year, out-year, or far-out-year). Associated with each of these numbers is a WM systems cost savings estimate to be realized in the specified year. System cost savings for an activity are cost reductions that occur at other funding units as a result of improvements at the funding unit that "claims" the cost savings. (For most funding unit alternatives, systems cost savings are expected to be zero.) Cost estimates are made in current-year dollars. 
Budget-year cost is the budget request for the current year and includes all expenses to be incurred in the budget year. The WM budget dollars are allocated to fund budget requests for funding units to maximize the value of the portfolio (the collection of all funded activities). Budget-year costs are figured for activities and added to the budget-year costs of other activities to form a budget-year cost for a funding unit alternative. Each funding unit has as many budget-year cost figures as funding unit alternatives.

It is not necessary to specify out-year costs for all out-years over the life of the proposed project. Costs for out-years 1-4, which have been estimated for the budget case presented in the Environmental Restoration and Waste Management Five-Year Plan for Fiscal Years 1994-1998, and costs for one typical far-out-year are specified. The estimate for the typical far-out-year represents all years beyond out-year 4. The number of years to which this typical far-out-year applies is specified on line 31. Thus, a project having a 15-year life cycle starting in the budget year would have entries in the budget year, out-years 1-4, and a typical far-out-year assumed to represent the remaining 10 years of the project (Appendix A).

Costs are estimated in current-year dollars. Guidance on factors needed to make these estimates (e.g., escalation rates) will be provided in DOE Headquarter's guidance.

Out-year costs capture the out-year implications of a project. For example, construction costs for new projects are initially high but may lead to decreased operating costs in the future (compared with continued operation of an inefficient facility). The outyear cost measure thereby captures the benefits of lower operating costs in the future if a new facility were constructed.

By viewing the entire life cycle of the facility, RASS considers the overall impacts and costs of proposed work. Therefore, when costs for an activity are extended over a specified period, the scores for other RASS scales should be provided for the same period. Otherwise, if only the first year of construction were considered, the waste managed for a new facility would be zero. If proposed work had no cost or impact beyond the budget year, the RASS scores would simply account for the effects in that year.

Sample input data for RASS are shown in Appendix C. RASS computes the present value $^{2}$ of the WM systems cost to represent the time stream of costs. When costs and impacts are only relevant for the budget year, those single values are used. When a time stream (estimates for the budget year and one or more out-years) exists, the WM systems cost computed by RASS is the present value of the time stream.

2 A real discount rate is used in the present-value analysis for the cost stream, e.g., $10 \%$ per year. Effects other than cost are not present-valued. Instead, a simple annual average is used (equivalent to a discount rate of 0.0 ). Fiscal year 1994 is the base year for the present value of costs. 


\section{D.4.2 Fines (Line 32)}

Failure to meet compliance regulations results in fines, thereby increasing the WM systems cost. Therefore, it is necessary to predict which violations will or might occur under different alternatives and then sum for each year the fines mandated by such violations. These amounts are specified on line 31. All other information regarding fines is specified in the notes space (line 14, form 1) or in a separate attachment.

\section{D.4.3 Cost Penalties (Line 33)}

One activity can increase systems costs for other activities. For example, one activity could raise another activity's overhead or prevent another activity from occurring, thereby resulting in fines. The dollar amount of all such impacts is specified on line 33.

\section{D.4.4 Cost Savings (Line 34)}

The opposite of cost penalties is cost savings, where one activity can decrease system costs for other activities. For example, one activity may be partially funded by another activity, decrease another activity's overhead, or allow another activity to avoid a fine. The dollar amount of such savings is specified on line 34 .

\section{D.5 WASTE MINIMIZATION (Line 35)}

Waste minimization activities range from training in waste minimization to redesign of processes to reduce future waste. The total dollar amount spent on waste minimization activities gives credit for the benefits of those activities in proportion to their anticipated value. When a proposed waste minimization activity also affects attainment of other objectives, scoring of those objectives also accounts for effects of attainment. RASS considers spending on waste minimization activities similar to the way it considers spending on S\&H activities.

\section{D.6 SOCIAL IMPACTS (Lines 36-39)}

Waste management activities can disrupt normal activities (e.g., by causing anxiety to nearby residents or preventing people from entering areas). The impact of WM activities might be a nuisance (e.g., losing access to a local recreational fishing stream) or be of more critical importance to the parties involved (e.g., restricting access to ancestral lands). To capture such effects, RASS uses the "social impacts" objective, which consists of public concern, and short- and long-term land access and use. 


\section{D.6.1 Public Concern Code (Line 36)}

To estimate concern about WM activities, RASS considers both the level of public concern and the degree to which the greatest concern can be reduced. Table D.7 lists levels of public concern, as specified by a five-point constructed scale. Each level considers the percentage of local residents that expresses fear or mistrust, the number of groups that expresses concern or opposition, and the degree of national political or media attention. Scoring public concern involves specifying one of the five levels defined in Table D.7 and the degree (expressed as a percent) by which the worst level of concern is reduced.

TABLE D.7 Constructed Scale for Public Concern ${ }^{a}$

Scale

Level

Description

A No public concern. No local residents express fear or mistrust about this activity. Regional activist groups do not oppose this activity. No national political or media attention is given to this activity.

B Minor public concern. A few local residents express fear and mistrust about this activity. One regional activist group opposes this activity. Very little national political or media attention is given to this activity.

C Moderate public concern. Few local residents (about 10\%) express fear and mistrust regarding this activity. Several regional activist groups oppose this activity. Minor national media coverage and some national political interest are expressed about this activity.

D High public concern. Half of the local residents express fear and mistrust regarding this activity. Most regional activist groups concerned with waste management oppose this activity. Substantial national media coverage is given to this activity, and some political activities occur that could lead to congressional action regarding this activity.

E Very high public concern. Most local residents (about 75\%) express fear and mistrust regarding this activity. All regional groups concerned with waste management and several other groups oppose this activity. Frequent national media coverage occurs, and substantial national political activity, including congressional investigations, is present.

a Letters denote level of concern from low (A) to high (E); use with line 36 of form 2 . 


\section{D.6.2 Cultural Impacts (Line 37)}

To estimate the impact from WM activities to cultural resources, RASS considers the effects of these activities on historical, archaeological, and religious sites, as well as the significance of the site and the level of damage to the site. Each of these components is described by a constructed scale. Tables D.8 and D.9 list the significance and damage scales, respectively. The four-point significance scale ranges from a site that is not significant enough to warrant preservation to a site of national significance. The four-point damage scale ranges from no damage to the site or interference with site use to complete destruction or loss of use of the site.

\section{D.6.3 Short-Term Use (Line 38)}

To estimate the impact of WM activities on short-term land use, RASS considers the quality of and demand for land, the time of restriction, and the amount of land. The quality of and demand for land are specified by a five-point constructed scale that ranges from no use or demand for the land to a need for high-quality land (Table D.10). The time of restriction and the amount of land are directly specified.

\section{D.6.4 Long-Term Land Use (Line 39)}

To estimate the impact of WM activities on long-term land use, RASS considers (1) the characteristics of the waste permanently disposed on-site and (2) the amount of land permanently restricted from access and use because of waste disposal. The first component is specified by a five-point constructed scale that ranges from no harmful wastes to mixed hazardous wastes with high-level components (Table D.11). The amount of land affected is directly specified in acres.
TABLE D.8 Cultural Impacts: Significance of the Site under Consideration for Preservation ${ }^{\text {a }}$

\begin{tabular}{cl}
$\begin{array}{c}\text { Scale } \\
\text { Level }\end{array}$ & \multicolumn{1}{c}{ Description } \\
\hline A & No significance \\
B & Local significance \\
C & Regional significance \\
D & National significance \\
\hline a & $\begin{array}{l}\text { Letters denote level of severity } \\
\text { from low (A) to high (D); use with } \\
\text { line 37a of form 3. }\end{array}$
\end{tabular}

TABLE D.9 Cultural Impacts: Damage to the Site or Interference with Site Use

\begin{tabular}{l} 
Scale \\
Level $\quad$ Description \\
\hline
\end{tabular}
A No damage to the site or interference with site use
B Site access restricted for 25 years, but no damage
C $\quad 50 \%$ of the site is damaged
D Site is destroyed completely or can never be used

a Letters denote level of severity from low (A) to high (D); use with line 37b of form 3 . 
TABLE D.10 Short-Term Land Use: Quality of and Demand for Land ${ }^{\mathrm{a}}$

\begin{tabular}{cl}
$\begin{array}{r}\text { Scale } \\
\text { Level }\end{array}$ & \multicolumn{1}{c}{ Description } \\
\hline A & No use of or demand for the land \\
B & Low-quality land (e.g., desert) with low demand \\
C & $\begin{array}{l}\text { Moderate-quality land (e.g., agriculture, industrial) } \\
\text { with moderate demand (e.g., a proposal for industrial } \\
\text { development exists) }\end{array}$ \\
D & $\begin{array}{l}\text { High-quality land (e.g., homes, recreational activities } \\
\text { with moderate demand (e.g., proposal for housing } \\
\text { development or resort exists) }\end{array}$ \\
E & $\begin{array}{l}\text { High-quality land (e.g., homes, recreational activities) } \\
\text { with high demand (e.g., Native American claims to } \\
\text { use the land for hunting and fishing) }\end{array}$ \\
\hline
\end{tabular}

a Letters denote level of severity from low (A) to high (E); use with line 38a of form 3 .

TABLE D.11 Long-Term Land Ude: Characteristics of Waste Permanently Disposed On-site

\begin{tabular}{cl}
\hline $\begin{array}{r}\text { Scale } \\
\text { Level }\end{array}$ & \multicolumn{1}{c}{ Description } \\
\hline A & No harmful wastes \\
B & Hazardous organic waste \\
C & Hazardous metals \\
D & $\begin{array}{l}\text { Mixed hazardous metals and low-level } \\
\text { radioactive wastes }\end{array}$ \\
E & $\begin{array}{l}\text { Mixed hazardous wastes with some } \\
\text { high-level components }\end{array}$ \\
F & Transuranic or high-level wastes \\
\hline
\end{tabular}

a Letters denote level of severity from low (A) to high (F); use with line $39 \mathrm{a}$ of form 3. 


\section{D.7 ENVIRONMENTAL IMPACTS (Lines 40-41)}

To estimate the impact of WM activities on the environment, RASS considers biotic impacts (animals and vegetables) and natural resource impacts (minerals). These impacts are defined as changes from existing environmental conditions caused by the activities in question.

\section{D.7.1 Biotic Impacts (Line 40)}

To estimate the impact of WM activities on biota, RASS considers both the sensitivity of and the damage to biota. Both of these components are described by constructed scales. Tables D.12 and D.13 list the sensitivity and damage scales for biota, respectively. The fourpoint sensitivity scale ranges from species that are not sensitive, unique, or threatened/endangered to species that are threatened/endangered. The six-point damage scale ranges from no damage to elimination of a species or its habitat.

\section{D.7.2 Natural Resource Impacts (Line 41)}

To estimate the impacts from WM activities to natural resources, RASS considers both the sersitivity and the damage from these activities to natural resources. Both of these components are described by constructed scales. Tables D.14 and D.15 list the sensitivity and damage scales, respectively. The five-point sensitivity scale ranges from a resource that is not environmentally sensitive to a resource that is environmentally sensitive and protected. The six-point damage scale ranges from no degradation of use or damage to natural resources to a major (i.e., 50\%) loss of natural resources. 
TABLE D.12 Biotic Impacts: Sensitivity of Biota ${ }^{a}$

Scale

Level

Description

A Species are not sensitive, unique, or threatened/endangered

B Species are sensitive, but not unique to the area, but not threatened/endangered

C Species are sensitive and unique to the area, but not threatened/endangered

D Species are threatened/endangered

a Letters denote level of severity from low (A) to high (D); use with line 40a of form 3 .

TABLE D.13 Biotic Impacts: Damage to Biota

\section{Scale}

Level

Description

A No damage to biota

B Noise and vibration impacts only, leading to minor behavior changes of some species, but no reduction of species

C Minor (5\%) reduction of species

D Significant $(25 \%)$ reduction of species

E Major (50\%) reduction of species

F Elimination of species or of their habitat

a Letters denote level of severity from low (A) to high (F); use with line $40 \mathrm{~b}$ of form 3 . 
TABLE D.14 Natural Resource Impacts: Sensitivity of Natural Resource ${ }^{a}$

Scale

Level Description

A Not environmentally sensitive

B State-designated natural area, state-designated scenic or wild river

C Partially developed coastal barrier or federally designated scenic or wild river

D Natural preserve, national or state wildlife refuge, undeveloped coastal barrier, federal land

designated for the protection of natural ecosystems

E Marine sanctuary, national park, designated federal wilderness area, national monument, national seashore recreational area, national lakeshore recreational area

a Letters denote level of severity from low (A) to high (E); use with line $41 \mathrm{a}$ of form 3 .

TABLE D.15 Natural Resource Impacts: Damage to Natural Resource ${ }^{a}$

\begin{tabular}{cl}
\hline $\begin{array}{c}\text { Scale } \\
\text { Level }\end{array}$ & \multicolumn{1}{c}{ Description } \\
\hline A & No degradation of use or dámage \\
B & Aesthetic degradation of use only \\
C & $\begin{array}{l}\text { Degradation of use through noise, } \\
\text { vibration andianthetic impacts }\end{array}$ \\
D & Minor (5\%) loss of natural resource \\
E & Significant (25\%) loss of natural resource \\
F & Major (50\%) loss of natural resource \\
\hline
\end{tabular}

a Letters denote level of severity from low (A) to high (F); use with line $41 \mathrm{~b}$ of form 3. 
APPENDIX E:

\section{GLOSSARY}




\section{APPENDIX E:}

\section{GLOSSARY}

Activity. A specific proposal for work, such as new construction; an upgrade to an existing facility; routine maintenance; treating, storing, or disposing of waste; and monitoring the environment. One or more activities make up a funding unit.

Activity data sheet (ADS). A document used by the U.S. Department of Energy's Office of Environmental Restoration and Waste Management for planning and budgeting. The ADS consists of a brief description of the project, annual budget requests for a seven-year period, and key programmatic information.

Agreement. See Compliance agreement.

Alternative. See Funding unit alternative.

Appropriation. A funding decision made by Congress.

Benefits. The consequences of performing proposed work (e.g., reducing human safety and health risks and achieving compliance).

Budget year. The year for which the budget is being planned.

Case. A specific set of assumptions in budget guidance given by U.S. Department of Energy Headquarters to field offices for use in preparing funding unit alternatives.

Compliance agreement. A legally binding agreement between regulators and regulated entities that sets standards and schedules for compliance with environmental statutes. These agreements include consent order and compliance agreements, federal facility agreements, and federal facility compliance agreements.

Comprehensive Environmental Response, Compensation, and Liability Act (CERCLA). A federal statute (also known as Superfund) enacted in 1980 and reauthorized in 1986. CERCLA provides the statutory authority for cleanup of hazardous substances that could endanger public health, welfare, or the environment. Program activities include establishing the National Priorities List, investigating sites for inclusion on the list, determining their priority level on the list, and conducting and/or supervising the ultimately determined cleanup and other remedial actions.

Continuity of operations. U.S. Department of Energy installation activities that include developing strategic and long-range waste management plans, conducting surveillance and maintenance of facilities and equipment, performing waste certification, providing training programs for personnel, and providing administration of records and information. 
Cost profile. The year-by-year funding requirements for an activity or funding unit alternative.

Disposal. Waste emplacement designed to ensure isolation of waste from the biosphere, with no intention of retrieval for the foreseeable future. Disposal requires deliberate action to regain access to waste.

DOE orders. Internal requirements that establish U.S. Department of Energy policy and procedures for compliance with applicable laws and regulations.

DOE waste. The waste from any activity performed in whole or in part in support of U.S. Department of Energy activities in the areas of nuclear energy, defense, energy research, or Office of Environmental Restoration and Waste Management. Waste under the U.S. Nuclear Regulatory Commission or waste generated by the commercial nuclear power industry is excluded from this category.

Environmental restoration. Cleanup and restoration of sites contaminated with radioactive and hazardous substances during past U.S. Department of Energy (DOE) production activities. Environmental restoration is directed by DOE's Office of Environmental Restoration and Waste Management.

Facility. Buildings (and associated land, machinery, and apparatus) needed to carry out a specific waste management operation (e.g., Defense Waste Processing Facility at the Savannah River Site).

Field office. U.S. Department of Energy (DOE) offices in the field (i.e., Albuquerque, Chicago, Idaho, Nevada, Oak Ridge, Richland, San Francisco, and Savannah River). Field offices prepare work proposals and submit them to DOE Headquarters. Rocky Flats, an office (not a field office), also prepares work proposals.

Funding unit. The logical groupings of activities consistent with U.S. Department of Energy Office of Waste Management program planning and management philosophy. A funding unit is an installation (e.g., Los Alamos National Laboratory), a facility (e.g., Toxic Substances Control Act Incinerator), or a major activity (e.g., environmental monitoring at a large installation).

Funding unit alternative. A specific set of proposed activities for a particular funding unit.

Hazardous waste. As defined in the 1976 Resource Conservation and Recovery Act, a solid waste or combination of solid waste that, because of its quantity, concentration, or physical, chemical, or infectious characteristics, may cause or significantly contribute to an increase in mortality or an increase in serious, irreversible, or incapacitating reversible illness or pose a substantial present or potential hazard to human health or the environment when improperly treated, stored, transported, or disposed of, or otherwise managed. 
Headquarters. The U.S. Department of Energy Office of Environmental Restoration and Waste Management offices in Washington, D.C., where the Office of Waste Management is located.

High-level waste. The highly radioactive waste material that results from the reprocessing of spent nuclear fuel that contains a combination of transuranic waste and fission products in concentrations that require permanent isolation. High-level waste includes liquid waste produced directly in reprocessing operations and any solid waste derived from the liquid.

Implementation. With respect to the Resource Allocation Support System (RASS), the use of RASS by Headquarters and field offices.

Installation. A geographic location (generally consisting of multiple facilities) where the U.S. Department of Energy has waste management responsibility (e.g., Brookhaven National Laboratory, Kansas City Plant, Ames Laboratory, Fermilab).

Low-level waste. A radioactive waste not classified as high-level waste, transuranic waste, spent nuclear fuel, or by-product material.

Mixed waste. The waste that contains both radioactive and hazardous components, as defined by the Atomic Energy Act and the Resource Conservation and Recovery Act, respectively.

Monitoring. The periodic or continuous measurement of the quantity and type of discharges or migration of radioactive waste from a management facility to determine the level of compliance with statutory requirements and/or pollutant levels in various media.

Objective. A general statement that defines what one wants to achieve that is characterized by a decision context, an object, and a direction of preference. For example, one possible objective for the Resource Allocation Support System (RASS) is to minimize human safety and health risks. With this objective, the decision context is funding waste management activities, the object is human safety and health risk, and the direction of preference is less impact.

Off-site facility. A hazardous waste treatment, storage, or disposal area that is not located at the generating site.

On-site facility. A hazardous waste treatment, storage, or disposal area that is located at the generating site.

Operations alternative. A funding unit alternative that includes all operating, maintenance, and capital expenses needed to conduct scheduled waste operations activities in a safe, efficient manner that ensures compliance will all applicable laws, regulations, and agreements. 
Option. A U.S. Department of Energy possible funding choice among a number of proposed activities.

Performance assessment. The activities (qualitative and quantitative) carried out to (1) detcrmine the long-term ability of a site or facility to effectively isolate waste and ensure the long-term safety and health of the public and (2) provide the basis for demonstrating regulatory compliance. Performance assessment serves as a focal point for site characterizations, model development, and uncertainty analysis research activities.

Permit. An authorization, license, or equivalent control document issued by the U.S. Environmental Protection Agency or an approved state agency to implement the requirements of an environmental regulation (e.g., a permit to operate a wastewater treatment plant or to operate a facility that may generate harmful emissions).

Radioactive waste. A solid, liquid, or gaseous material of negligible economic value that contains radionuclides in excess of threshold quantities. Radioactive waste does not include material contaminated by radionuclides from nuclear weapons testing.

Resource Conservation and Recovery Act (RCRA). An amendment to the Solid Waste Disposal Act, passed in 1976 to address the problem of how to safely dispose of municipal and industrial solid waste generated nationwide. RCRA established a national policy to reduce or eliminate hazardous waste and conduct treatment, storage, or disposal operations to minimize its threat. The 1984 Hazardous and Solid Waste Amendments amended RCRA, expanded RCRA's scope, and added detailed requirements. RCRA Part A permit applications identify treatment, storage, and disposal units within a to-be-permitted facility. RCRA Part B applications describe in detail wastes managed, quantities, and facilities.

Resource Allocation Support System (RASS). A decision-aiding system to support U.S. Department of Energy's Office of Waste Management program and budget decisions.

Sanitary waste. The waste (e.g., garbage) generated by normal housekeeping activities. Sanitary waste is neither hazardous nor radioactive. It is disposed of in sanitary landfills and includes liquids treated in sewage treatment plants.

Score. The rating of a funding unit alternative against a particular Resource Allocation Support System (RASS) objective or subobjective.

Site. The lands, installations, or facilities for which the U.S. Department of Energy has or shares responsibility for environmental restoration and waste management activities. 
Solid waste. Nonliquid, nonsoluble materials ranging from municipal garbage to industrial waste that contains complex, and sometimes hazardous, substances. Included in this category are sewage sludge, agricultural refuse, demolition wastes, and residues. Technically, this category of waste also refers to liquids and gases in containers.

Standby alternative. A funding unit alternative that accounts for minimum funding needed to maintain equipment in a standby mode with no operating funds.

Storage. The retention and monitoring of waste in a retrievable manner pending final disposal.

System cost. The total present value of the Office of Waste Management's program cost commitment associated with a specific target-year funding request for an activity. System cost includes target-year cost as well as future costs for building a facility. Cost profiles account for cost savings or increases relative to other activities.

Transuranic waste. Waste that is contaminated with alpha-emitting transuranium nuclides with half-lives greater than 20 years and concentrations greater than $100 \mathrm{nCi} / \mathrm{g}$ of waste.

Treatment. An activity that alters the chemical or physical nature of hazardous waste to reduce its toxicity, volume, or mobility, or to render it amenable for transport, storage, or disposal.

Tri-Party Agreement. An agreement signed by the U.S. Department of Energy, the U.S. Environmental Protection Agency, and states that identifies milestones for key waste management actions.

Toxic Substances Control Act (TSCA). An Act enacted in 1976 to protect human health and the environment from unreasonable risk due to exposure to, manufacture, distribution, use, or disposal of substances that contain toxic chemicals. For example, under TSCA, any hazardous waste that contains more than 50 parts per million of polychlorinated biphenyls (PCBs) is subject to regulations.

Waste minimization. The reduction, to the extent feasible, of radioactive and hazardous waste that is generated before treatment, storage, or disposal of the waste. Waste minimization includes any source reduction or recycling activity that reduces the total volume of hazardous waste or the toxicity of hazardous waste or both.

Waste operations. Activities conducted under the direction of the U.S. Department of Energy's Office of Environmental Restoration and Waste Management.

Waste stream. The waste generated at a facility or operation. 

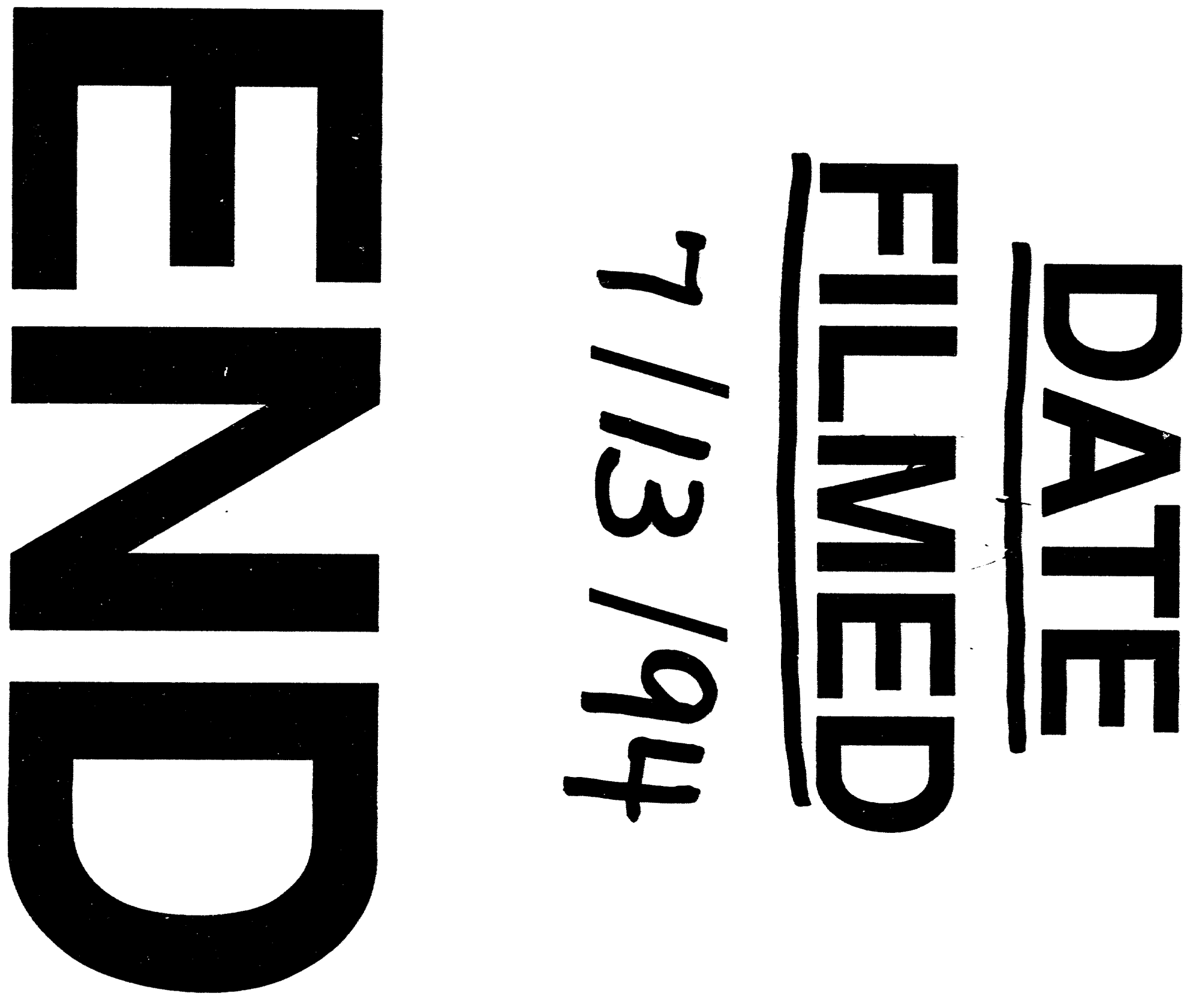
